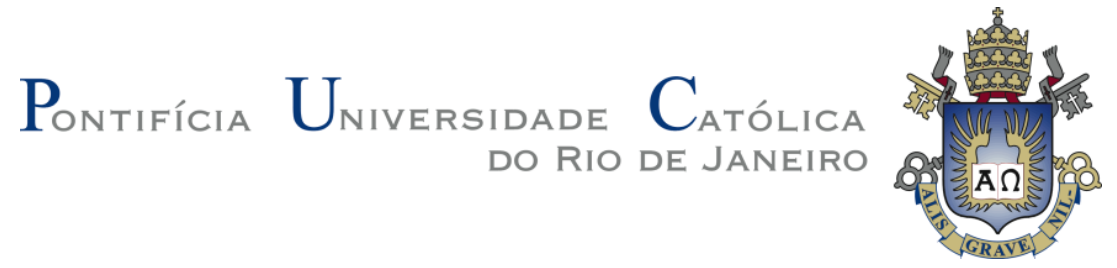

Clarisse Fraga Zarvos

DRAMATURGIA DE GESTOS

Dissertação de Mestrado

Dissertação apresentada como requisito parcial para obtenção do grau de Mestre pelo Programa de Pós-Graduação em Literatura, Cultura e Contemporaneidade do Departamento de Letras da PUC-Rio.

Orientadora: Profa. Ana Paula Veiga Kiffer Co-orientadora: Profa. Helena Franco Martins 
Clarisse Fraga Zarvos

\title{
DRAMATURGIA DE GESTOS
}

Dissertação apresentada como requisito parcial para obtenção do grau de Mestre pelo Programa de PósGraduação em Literatura, Cultura e contemporaneidade do Departamento de Letras do Centro de Teologia e Ciências Humanas da PUC-Rio. Aprovada pela Comissão Examinadora abaixo assinada.

\author{
Profa. Ana Paula Veiga Kiffer \\ Orientadora \\ Departamento de Letras - PUC-Rio \\ Profa. Helena Franco Martins \\ Co-orientadora \\ Departamento de Letras - PUC-Rio
}

Profa. Mariana Maia Simoni

Departamento de Letras - PUC-Rio

Profa. Rosyane Trotta

UNIRIO

Profa. Denise Berruezo Portinari Coordenadora Setorial do Centro de Teologia e Ciências Humanas - PUC-Rio

Rio de Janeiro, 01 de abril de 2014 
Todos os direitos reservados. É proibida a reprodução total ou parcial do trabalho sem autorização da universidade, do autor e do orientador.

\section{Clarisse Fraga Zarvos}

Graduou-se em Bacharelado em Artes Cênicas com habilitação em Interpretação Teatral, pela Universidade Federal do Estado do Rio de Janeiro (UNIRIO), em 2010. Cursou Pós-graduação Lato Sensu em Docência do Ensino Fundamental e Médio pela Universidade Cândido Mendes. Participou de seminários na área de Literatura e Artes Cênicas. Sua pesquisa tem como enfoque produções artísticas e teórico-críticas que atravessam questões como corpo, linguagem e dramaturgia.

Ficha Catalográfica

Zarvos, Clarisse Fraga

Dramaturgia de gestos / Clarisse Fraga Zarvos ; orientadora: Ana Paula Veiga Kiffer ; coorientadora: Helena Franco Martins. - 2014. 100 f. ; $30 \mathrm{~cm}$

Dissertação (mestrado)-Pontifícia Universidade Católica do Rio de Janeiro, Departamento de Letras, 2014.

Inclui bibliografia

1. Letras - Teses. 2. Gesto. 3. Dramaturgia. 4. Presença. 5. Dança. 6. Artes cênicas. I. Kiffer, Ana Paula Veiga. II. Martins, Helena Franco. III. Pontifícia Universidade Católica do Rio de Janeiro. Departamento de Letras. IV. Título. 


\section{Agradecimentos}

À Capes, pela bolsa de pesquisa que me foi concedida durante o curso de mestrado.

Às pessoas mencionadas aqui: qualquer tentativa de agradecimento será sempre insuficiente.

À professora Ana Kiffer, minha orientadora;

À professora Helena Martins, minha co-orientadora;

Aos professores e professoras que, em sala de aula ou fora dela, me instigaram e me deram apoio: Marília Rothier Cardoso, Mariana Maia Simoni, Vera Follain de Figueiredo, Alexandre Montaury e Rosana Kohl Bines;

Aos colegas de Pós-graduação Adriana Azevedo, Felipe Wircler Machado, Natalie Araújo Lima e em especial, Manoela Sawitzki;

À Daniele de Oliveira Cruz pela atenção e paciência;

Ao Coletivo Oh, Céus!, principalmente aos diretores Helena Bittencourt e Goos Meeuwsen, pela parceria, pela inspiração e pelos ensinamentos que só são possíveis na experiência;

Ao Laboratório de Diagramas Móveis, realizado pelo Brecha Coletivo e idealizado por Patrick Sampaio;

Ao Caio Riscado, da Realizadora Miúda, pelas discussões, pelas criações e pela capacidade de tornar as coisas mais claras;

Ao João Saldanha, pela residência realizada no Teatro Poeira entre dezembro de 2013 e fevereiro de 2014;

Às amizades, parcerias e outros afetos que vêm me acompanhando ao longo destes dois anos e que, direta ou indiretamente influenciaram nos rumos desta dissertação: Ana Paula Muniz, Alice Ripoll, Ria Marks, Thierry Trémouroux, Raquel Karro, Coletivo Instrumento de Ver, Luisa Buarque de Holanda, Augusto Malbouisson, Cecília Ripoll, Fernando Klipel, Mayara Yamada, Catharina Caiado, Daniel Pech, Dominique Thomaz, Andrea Capella, Eva Randolph, Barbara Kahane, Monique Cruz, Luiza Cascon, Guilherme Zarvos, Joana Magalhães, Luis Felipe Carvalho, Luar Maria e Marcos Nery;

À minha família. 


\section{Resumo}

Zarvos, Clarisse Fraga; Kiffer, Ana Paula Veiga. Dramaturgia de Gestos. Rio de Janeiro: 2014. 100p. Dissertação de Mestrado - Departamento de Letras, Pontifícia Universidade Católica do Rio de Janeiro.

A dissertação "Dramaturgia de Gestos" apresenta uma reflexão teóricoconceitual sobre a noção de "gesto" voltada para a escrita cênica. A pesquisa se concentra na percepção da influência de certos elementos referentes ao conceito em questão, em projetos de artes performativas (dança, teatro, perfomance) com ênfase no distanciamento de valores e procedimentos do modelo de teatro "dramático", observados a partir dos anos 70 e sobretudo, em seus desdobramentos, atualmente, na primeira década do século XXI. Importante marcar que não se trata de tentar localizar e atribuir valor à presença do gesto em determinadas obras, como se o conceito abarcasse pressupostos e medidas prédeterminados. Pelo contrário, a noção de gesto se interessa justamente pela desarticulação de modelos unitários e discursos assertivos, pertencentes às instituições e aos organismos de poder. A partir da ideia de cartografia a pesquisa traça paralelos entre gesto, presença, experimentação, ruptura, temporalidade e linguagem. Os conceitos de Diagrama e Corpo Sem Orgãos, de Gilles Deleuze auxiliam na compreensão da dramaturgia como um conjunto operatório de traços e linhas, composto por molduras e limites, borrados por manchas assignificantes e não-representativas, compreendidas como "zonas de caos". A "catástrofe" ou o "caos" funcionam como ferramentas de desarticulação da estrutura, abrindo espaço para a incidência de momentos daquilo que tenta se compreender como gesto.

\section{Palavras-chave}

Gesto; dramaturgia; presença; dança; Artes Cênicas. 


\section{Résumé}

Zarvos, Clarisse Fraga; Kiffer, Ana Paula Veiga (Directeur Recherche). Dramaturgie de Gestes. Rio de Janeiro: 2014. 100p. Dissertation de Maîtrise - Departamento de Letras, Pontifícia Universidade Católica do Rio de Janeiro.

La thèse "Dramaturgie de Gestes" présente une réflexion théorique et conceptuelle sur la notion de "geste" dirigée vers l'écriture scénique. La recherche se concentre sur la perception de l'influence de certains éléments relatifs à la notion en question, dans des projets d'arts de la scène (danse, théâtre, performance), en mettant l'accent sur les valeurs et les procédures du modèle "dramatique" de théâtre, observés à partir des années 70 et surtout, dans son déroulement, actuellement, dans la première décennie du XXI siècle. C'est important de souligner qu'il ne s'agit pas de chercher à localiser et assigner une valeur à la présence du geste dans certaines œuvres, comme si le concept engloberait des hypothèses et des mesures prédéterminées. Au contraire, la notion de geste s'intéresse précisément à la désarticulation des modèles unitaires et des discours affirmatifs, qui appartiennent aux institutions et aux organes du pouvoir. De l'idée de cartographie, la recherche établit des parallèles entre le geste, la présence, l'expérimentation, la rupture, la temporalité et le langage. Les concepts de Diagramme et de Corps Sans Organes, de Gilles Deleuze, aident à comprendre la dramaturgie comme un ensemble opératoire de traits et de lignes, composé par des cadres et des bordures, brouillé par des taches non-signifiantes et nonreprésentatives, entendues comme des "zones de chaos". La «catastrophe» ou le «chaos» agissent comme des outils de la désarticulation de la structure, faisant place à l'incidence des moments de ce que s'essaie de comprendre comme geste.

\section{Mots-clés}

Geste; dramaturgie; présence; danse; arts de la scène. 


\section{Sumário}

$\begin{array}{ll}\text { 1. Ponto de Partida } & 10\end{array}$

2. O Gesto e a Dança, O Gesto na Dança ou "Porque Abordar o Gesto a Partir da Dança Contemporânea?"

3. Uma Breve Cartografia do Gesto: 19

3.1. Gesto e Presença 21

3.2. Gesto e Experimentação 30

3.3. Gesto e ruptura 33

3.4. Gesto e multiplicidade $\quad 37$

3.5. Gesto e temporalidade 39

3.6. Gesto e "Língua Menor" 44

4. Uma Dramaturgia de Gestos 51

5. (In)conclusão

7. Referências bibliográficas 90 
O que define um gesto? Onde ele começa? Quais as relações entre gesto, postura, atitude, intenção, pensamento, movimento, contexto, linguagem, comunicação? Que gestos nos afetam? Que gestos nos formaram? Que gestos cada um de nós escolheria para uma lista dos 100 mais significativos dos últimos séculos? Ou os 100 mais significativos da própria vida? Uma dança é sempre feita de gestos? O que será que um inventário de gestos pode revelar sobre as escolhas afetivo-estético-éticopolíticas dos corpos e das suas danças?

Dani Lima 


\section{Ponto de Partida}

Desde o meu ingresso como aluna da Pós-Graduação três filmes, que ocupam uma zona fronteiriça entre a dança e uma atuação mais "teatral", vêm acompanhando o desenvolvimento de escrita desta dissertação. São eles: "The Cost of Living”(do grupo inglês "DV8 Physical Theatre", 2005), "Blush" (da companhia belga "Última Vez" e direção de Win Vandekeybus, 2005) e "Valse Wals" (do coletivo holandês “Orkater", 2005). O que a princípio chamou a minha atenção nos três filmes foi justamente um investimento do corpo, das posturas e do movimento - cada um à sua maneira - que eu não conseguia definir. Às vezes eu reconhecia imediatamente aquelas relações corporais no meu cotidiano e em pessoas à minha volta, no entanto, outras vezes, a partir desse reconhecimento, a forma do corpo se transformava, se deformava, a ponto de me parecer inédita e de me apontar fisicalidades que eu quase não podia supor que existiam. Era naquilo que me parecia surpresa, que alguma coisa muito óbvia sobre o estar no mundo se revelava. Uma tensão entre o conhecido e o inédito, que eu não conseguia explicar. Um misto da sensação de estar diante de uma novidade e a de estar diante de um óbvio tão óbvio que só a experiência poética poderia me revelar.

Durante um tempo considerável me perguntei se aqueles corpos pertenciam mais ao campo de reconhecimento da dança, do teatro, do cinema, da performance, das artes plásticas ou do "dia-a-dia”. Se é que existia um corpo para cada ocasião. Essa zona de trânsito e indefinição de gêneros, que falando assim não é nenhuma novidade nos projetos de Arte Contemporânea, me afetou muito. Existiria um corpo da dança, um do teatro, um do cinema e um da vida comum? Quais seriam as características e as relações dos corpos com o espaço e o tempo, que permitiriam atribuir uma fisicalidade mais a uma categoria do que a outra? Só depois de iniciar a pesquisa, descobri que essas obras são adaptações audiovisuais de espetáculos originalmente desenvolvidos para o palco. Ou seja, os trabalhos em questão foram criados para serem apresentados ao vivo, sendo posteriormente filmados e transpostos para a tela. $\mathrm{O}$ que muda nesta transição de suporte são as paisagens e a relação com a presença do público. Esse dado de transição de meios me inquieta pela 
impossibilidade de catalogação da obra em uma categoria fechada ou até mesmo em uma única obra. Não tive a oportunidade de assistir ao vivo nenhum dos espetáculos, só vídeos de apresentações filmadas. Apesar do foco desta dissertação não ser a mudança de suportes, acho interessante observar como esses trabalhos ressaltam o trânsito de determinadas interações entre os elementos cênicos, que aqui chamamos de "dramaturgia". Há uma dramaturgia comum que se mantém na peça e no filme, que poderíamos reconhecer como coreografias, partituras, situações ou "marcações" espaciais. Alguma coisa que lida com a repetição de determinadas relações espaço temporais e afetivas entre os elementos. Entretanto, há também uma outra camada. E é a diferente afetação que a obra produz, seja no teatro, seja na tela, que chama a nossa atenção. Esses filmes, que um dia foram espetáculos, se recusam a encerrar-se em uma única obra, provocando uma reflexão acerca de certos lugares impostos aos corpos, em uma sociedade cujos aparatos de poder prezam pelas categorias, normas e padrões. A relação de estranhamento/ reconhecimento dos corpos e a transposição de uma mesma coreografia em diferentes meios, são fatores que instigam a pesquisa sobre o gesto, justamente pela indiscernibilidade e pelo impedimento de atribuição de um valor unitário ao corpo ou a um gênero fixo.

Qual o corpo que interessa ao gesto? Difícil saber, pois o gesto não reconhece um corpo ou $o$ corpo. O corpo do gesto coloca incontáveis possibilidades de corpos e de devires. É um corpo que não é nem só um, nem só outro. Isso não significa que seja sempre indeterminado ou que hesite em frequentar zonas extremas. Trata-se de um outro tipo de relação. Esse corpo que não é nem só esse, nem só aquele é também, no mesmo corpo, um corpo $e$ outro corpo. Entre um e outro. Um corpo que é vários corpos, vários tempos, vários lugares, às vezes completamente improváveis e até contraditórios. Ao invés da fixação em uma identidade, o que emerge do gesto, são corpos vibráteis e escritas de passagens.

Minha ideia inicial era desenvolver três pequenos ensaios, analisando os filmes sob a perspectiva do que se aprofundaria como a "dramaturgia do gesto". No entanto, ao longo da pesquisa, senti que esse caminho poderia acabar engessando o trabalho. De certa modo, ao fazer uma análise crítica dessa ordem, eu corria grande risco de colocar as obras como justificativa de um conceito. Na verdade, as obras tinham me impulsionado mais como uma indagação do que como uma resposta. Foi preciso deixar de lado a ideia de uma análise crítica que ilustrasse o conceito, para que minha relação com os objetos não me afastasse das inquietações. 
Mas como não abandonar completamente a motivação inicial? Como não deixar de lado esses afetos? Considerando que o interesse pelo lugar da dúvida na escrita da dança é um aspecto fundamental para esta pesquisa, convoco ao longo deste primeiro capítulo algumas "sequências" que nada mais são que pequenos textos, livremente inspirados em formatos de roteiro ou dramaturgia escrita, despertados por sensações e imagens que me atravessaram nos três filmes e que chamaram a atenção para a escolha dos eixos dessa discussão. Essas "cenas" que aparecem no início dos tópicos não têm a menor intenção de justificar ou de exemplificar os itens. As "encenações textuais" não são descrições precisas das imagens visuais ou de uma sequência narrativa (aliás, como seria possível?). Misturo situações e personagens dos filmes a sensações pessoais, memórias, imaginários, outras referências e outros escritos que eu tinha no meu computador e nos meus cadernos, construindo ao longo da dissertação (e junto dela), uma nova dramaturgia. Para quê? Apenas porque ainda queria tê-los um pouquinho por perto. 


\title{
2 \\ O Gesto e a Dança, O Gesto na Dança ou "Porque Abordar o Gesto a Partir da Dança Contemporânea?"
}

\author{
El verdadero lugar del bailarín no está en el cuerpo y en su \\ movimento , sino en la imagen como “cabeza de Medusa” como \\ pausa no inmóvil, sino cargada, al mismo tiempo, de memoria y \\ energia dinámica. Pero esto significa que la esencia de la danza no \\ es ya el movimento, es el tiempo.
}

Giorgio Agamben

O processo civilizatório se dá através de um adestramento do homem, que esculpe o corpo sob uma determinada forma. As instituições ditam quais contornos deve assumir um corpo saudável e feliz. Tecnologias disciplinares produzem um corpo dócil, inteligente, útil. A medicina e a biotecnologia, ao estabelecerem o que é a saúde e os meios de alcançá-la, muitas vezes acabam por negar o corpo, fazem calar a sua dor. Enquanto a medicina molda nossa conduta corporal, segundo preceitos científicos, a cultura da celebridade molda o corpo, a partir dos preceitos estéticos vigentes. O sistema penal estabelece quem deve ou não ser identificado como criminoso, quem merece a liberdade e quem merece a punição. A escola ensina como devemos nos comportar, como devemos nos sentar, o que devemos aprender. Isso sem falar na família, na religião e assim por diante. Corpos coletivos e individuais são "domesticados" por estes "corpos institucionais" através de discursos que impõem normas e padrões, modelos unitários e repetitivos de existência ${ }^{1}$.

Desarticular o que nos foi e ainda é tão fortemente articulado não é tarefa fácil. Contudo, sempre há brechas para subverter e apontar para a impossibilidade da unidade. Se as instituições (e aqui compreendemos a dificuldade de dizer "as" instituições, na medida em que cada uma tem a sua lógica e sua estrutura de funcionamento que se influenciam e se interpenetram) insistem em impôr lugares fixados do corpo no mundo e se nós, inseridos neste contexto, acabamos muitas vezes

\footnotetext{
${ }^{1}$ Parágrafo escrito a partir da fala de Peter Pal Pélbart em Encontros Provocativos 7/9- Bienal SESC de dança. Conversatório/Convivência - SESC Santos. http://revistapolichinelo.com.br. 12/29/2011.
} 
não só acatando, mas nos submetendo e repetindo seus discursos, devemos então pensar em outros meios de investigação da experiência com os corpos, no limiar entre a vida e a morte, o homem e o animal, a loucura e a sanidade, o nascer e o perecer. Mas será que somente nesses espaços ainda desconhecidos ou rejeitados pela norma é possível repensar e reinventar os corpos?

Por que falar em gesto? O que é que há na noção de "gesto" que a torna diferente do "ato", do "movimento" e da "ação"? Quando nos referimos a algum filósofo é comum dizermos que o gesto dele como pensador foi introduzir uma questão ou uma reflexão em determinado contexto. Da mesma forma, o gesto arquitetural, por exemplo, tem a ver com a inserção de algo que antes não se fazia presente. Mais do que a construção de um prédio ou de um monumento, o gesto nesse sentido, inventa um espaço, que só poderia ser pensado a partir daquele gesto. Há um caráter inventivo neste conceito, criativo, mas sobretudo da ordem da experiência. $\mathrm{O}$ gesto é sempre inaugural, pois ele funda uma experiência. Mas é importante lembrar que não se trata de uma experiência inédita, original. Para além disso, o que ele coloca é a possibilidade de uma experiência que não estava ali antes ${ }^{2}$.

Quando falamos de um gesto "notável", nos referimos à alguma coisa na presença de certos corpos que afeta de maneira contundente a relação destes com outros corpos. Corpos esses que podem ser humanos, institucionais ou elementos do espaço. Podem ser: um homem, um homem que não sai do lugar, um homem sem pernas, uma cabeça, uma boca que fala através de um orifício, um grito, um conceito, uma tinta, uma tela, uma fotografia, um muro, uma cachoeira, uma luz, uma página, um som, uma galinha, um espermatozoide, uma fonte, um rosto, uma criança, uma velha, um edifício em ruínas... Um corpo é um conjunto de relações cambiantes composto por elementos materiais/formais e forças imateriais/mutáveis. O gesto dialoga sempre com as relações do corpo no mundo.

Gesto e corpo são indissociáveis. Na vida cotidiana é comum chamarmos de "gesto" determinadas movimentações corporais que de alguma maneira dizem respeito à uma linguagem codificada comum. Os manuais do tipo "o corpo fala" se propõem a desvendar a mensagem dos gestos: braços cruzados significam que a pessoa não está disponível, ombros retraídos indicam timidez e insegurança. Nessa tentativa de codificar, acabam atribuindo somente um significado à forma física, que

\footnotetext{
2 Parágrafo a partir da fala de Tatiana Roque (ROQUE org. LIMA, Dani. 2013: p:133-147).
} 
chamam de "gesto". Os livros de autoajuda garantem o ensino das melhores posturas para uma entrevista de trabalho, mas na verdade o que ensinam é uma "impostura", do corpo, modos de esconder a sua fragilidade. Claro, não estão completamente errados, no sentido que lidam com um senso-comum cultural. No Ocidente, por exemplo, um polegar para o alto remete à asserção; um polegar para baixo, à negação e a palma da mão espalmada para frente, acenando de um lado para o outro, a um encontro ou a uma despedida. Mais do que uma única significação atribuída a uma determinada forma física, o que interessa no estudo sobre o gesto é a potência das infinitas asserções, negações e despedidas, contidas, por exemplo, em cada um desses gestos.

Empurrar sempre quer dizer afastar? ${ }^{4}$

Escolhemos a Dança Contemporânea para desenvolver a noção de "gesto", pelo princípio de experimentação do conceito na própria "carne" do bailarino. A pele é o material de escrita. Mas o que define a dança contemporânea? Uma simples alteração nos códigos corporais em relação a outras expressões em dança (ainda que alguns pontos em comum se mantenham como constantes)? Uma questão de reconhecimento exterior de vocabulário ou de forma?

A dança contemporânea assim como o cinema nasce no final do século XXI. Uma arte a princípio nova, que se utiliza do suporte mais antigo de todos: o corpo humano. O crítico John Martin, testemunha do surgimento da dança moderna americana, desde o final dos anos 20 afirma que o que importa na nova dança (termo utilizado na época) "não é $<<$ o que parece $>>$ ( $<<$ what it looks like $>>)$, mas $<<$ o que diz〉> (<<what does it says?>>)" (LOUPPE, 2012, p. 51). O que Martin parece perceber como atribuição a esta dança não é tanto o conforto de uma mensagem, mas o desejo de afastamento da dança à uma pura aparência de espetáculo. Laurence Louppe afirma que a Dança Contemporânea "não nasce da dança, mas de uma ausência de dança" (LOUPPE, 2012, p. 55). Isso não significa que ela não tome de empréstimo referências de outras técnicas de dança. Entretanto, o que marca essa ausência é o fato dela não querer, nem poder se afirmar como uma técnica ou uma

\footnotetext{
${ }^{3}$ Crítica aos manuais, aos livros de auto-ajuda e a utilização da palavra "impostura", a partir da Silvia Soter, no debate "Gesto e Movimento"do ciclo de conversas Corpo, com mediação de Dani Lima. Doc. Ocupação Dança para Cacilda. Teatro Cacilda Becker, 16/05/2012.

${ }^{4}$ Pergunta feita por Alice Ripoll e Dani Lima no debate "Gesto e Movimento", do ciclo de conversas Corpo. Doc. Ocupação Dança para Cacilda. Teatro Cacilda Becker, 16/05/2012.
} 
escola. Aliás, muitas das figuras que fomentam o seu surgimento e desenvolvimento, como Dalcroze ${ }^{5}$, por exemplo, não eram sequer bailarinos.

A "nova dança” é marcada por uma busca da consciência do lugar do corpo no mundo e o dançarino contemporâneo é aquele que escolhe o corpo como instrumento de conhecimento, de pensamento, de sensação e de expressão. Nessa busca tão povoada de dúvidas não é possível se chegar à uma verdade absoluta sobre o corpo e sua experiência. Não há uma lei ou um procedimento previamente impostos.

A dança desfaz a tradição ereta de um sujeito unificado e abre caminho para outros gestos. Desestrutura clichês de movimento. "Revela, repete, repensa e reinventa as formas" ${ }^{\prime 6}$. A respiração, a temperatura, os batimentos cardíacos e os sentidos são diretamente afetados durante o trabalho do dançante. Ela lida com o corpo no seu sentido mais próximo.

A investigação de uma poética a partir das texturas, apoios e flutuações do corpo é um aspecto absolutamente vital para este tipo de dança. Louppe fala de uma “emergência poética" (LOUPPE, 2012, p. 69). A Dança, ao repensar e redistribuir a anatomia e as funções anatômicas revela um corpo em processo de descoberta e invenção. Mas será possível inventar um corpo? Será possível reiventá-lo? De que maneira?

O que se cria através da compreensão e do aprofundamento nos corpos são modos de utilização da linguagem e materiais, a partir dos quais os grupos podem criar suas poéticas próprias, de acordo com o interesse de cada projeto. A Dança Contemporânea chama a atenção para as "zonas assémicas" do homem (LOUPPE, 2012, p. 73), ou seja, zonas que não costumam "controlar" o discurso, como as extremidades do corpo, as mãos e o rosto. A cabeça como suporte do rosto, não se coloca como lugar de monopólio do olhar, do sentido e da linguagem. Todo o corpo possui potencial de expressividade (desta outra expressividade, poética). Do mesmo modo, o pé não assume a função única de apoio. O corpo se descentraliza, investiga possibilidades e apoios para além do eixo vertical. A anatomia é revisitada, chamando

\footnotetext{
5 Émile Jacques-Dalcroze (1869-1950), músico suíço, criador de um sistema ritmico musical baseado em passos de dança.

${ }^{6}$ Fala de PELBART, Peter Pal. Encontros Provocativos 7/9- Bienal SESC de dança. Conversatório/Convivência - SESC Santos. http://revistapolichinelo.com.br. 12/29/2011. Acesso em 25/12/2012.
} 
a atenção para outras formas, além das conhecidas e admitidas, "corpos poéticos suscepíteis de transformar o mundo mediante a transformação da sua própria matéria" (LOUPPE, 2012, p. 74-75).

Elegemos a "dança contemporânea" como território de investigação, cientes da dificuldade de localizá-la como corpus de estudo, visto que esta possui inúmeras facetas e modos de lidar com a realidade do corpo. Afinal, não existe $a$ Dança Contemporânea. Inclusive os próprios trabalhos citados como fonte de inspiração para "as cenas" deste capítulo, caminham por referências do teatro, da dança, do circo, entre outras abordagens. Falamos em dança porque é preciso de alguma forma identificar o objeto.

O que nos interessa nesse campo artístico é justamente o seu caráter mutável, onde cada projeto estético dialoga de modo diferente com o seu entorno, solicitando diferentes técnicas e referências na busca pelo seu próprio caminho, a partir de uma relação de projeção que pões em crise códigos linguísticos instituídos. A dúvida interessa muito a essa pesquisa, muito mais do que a resposta. "O que distingue um espetáculo de dança contemporânea é a pergunta que ele faz. (...) A dança que indaga, cabe dentro da nomeação de contemporânea. E a dança que não interroga seu público pertence a outra espécie" (KATZ, 2004). Importantíssimo não colocar a "dança que indaga" em oposição antagônica à "dança que não interroga". Afinal de contas não há um critério específico para se avaliar esse tipo de relação, nem a divisão binária interessa ao gesto. Destaquemos da definição de Katz, um desejo por um corpo que não se encerra na conclusão de uma resposta está sempre a se redescobrir. Pensemos, em "dança contemporânea" não como um gênero, mas como um devir. Se a dança não se encerra em uma forma, também não é capaz de pertencer a uma categoria.

O que nos atrai na dança é o investimento de um corpo que se assume mais como um feixe de forças e afetos do que como um sujeito ou uma forma unificados por discursos de poder.

O corpo da Dança é atravessado por um rede de interferências e tensões que excede suas próprias dimensões. Ninjinsky ${ }^{7}$, por exemplo, reinventa expressões e exposições corporais, a partir de uma série de desvios, abrindo caminho para uma multiplicidade de possibilidades do corpo até então não aparentes. Do mesmo modo, tantos outros artistas põem em destaque corpos que a princípio não estariam ao

\footnotetext{
7 Vaslav Ninjinsky, 1890-1950, bailarino russo de origem polaca, considerado um dos maiores bailarinos do seu tempo.
} 
alcance da nossa percepção: "corpos fracos, irrisórios e insensatos" (LOUPPE, 2012, p. 75), descentrados, desconjuntados, desaparafusados. Corpos nunca finalizados, sempre em vias de tornar-se um outra coisa. 


\section{3 Uma Breve Cartografia do Gesto:}

Gesture is the name of this intersection between life and art, act and power, general and particular, text and execution. It is a moment of life subtracted from the context of individual biography as well as the moment of art subtracted from the neutrality of aesthetics: it is pure praxis. Giorgio Agamben

CENA 1. Zona Portuária. Final da Tarde. Um marinheiro - vamos chamá-lo de Titus - no convés de um navio acena para a mulher amada (Maria Helena). Os dois, muito jovens, se conheceram na noite anterior. Parece pouco, mas o tempo é outro quando se trata das paixões. Talvez eles não se vejam nunca mais. Nunca se sabe, a vida é imprevisível ${ }^{8}$.

O gesto nessa cena não é só forma física, nem apenas convenção. Faz parte de uma linguagem corporal comum, está presente em um código linguístico, no entanto vai além da linguagem. Ao mesmo tempo em que marca uma_diferença na vida dos personagens envolvidos, carrega em si a repetição de infinitas partidas de conhecidos e desconhecidos de outras épocas e lugares. Não é o primeiro e certamente não será o último "adeus". É passado, presente e futuro de infinitos “adeus" possíveis e impossíveis até então. É pessoal e no entanto não é, na medida em que concerne a todos. É o extremo da relação entre "eu" e o "meu corpo" e o máximo da ausência dessa relação.

As passagens sublinhadas são uma espécie de norte, que vem me orientando nesta tentativa de falar sobre algo que desafia a certeza das formas e das palavras. Por enquanto, faço essas escolhas já duvidando delas e pensando que se tivesse escrito isto em uma outra época teria feito outras escolhas. Talvez amanhã ou daqui há alguns anos, ao reler esta dissertação, eu pense diferente e eleja novas abordagens que me pareçam mais apropriadas. As escolhas deste capítulo são como as luzes de um farol, que iluminam os navios-recortes, que por acaso passam.

\footnotetext{
${ }^{8}$ Cena livremente inspirada nas cenas de Valse Wals Film, do Grupo Orkater (2005).
} 
Por que fazer cartografia? Enquanto o mapa, para os geógrafos, lida com a representação de um todo estático, a cartografia é um desenho que acompanha e se faz ao mesmo tempo que os movimentos de transformação da paisagem. Segundo Suely Rolnik (1989) ${ }^{9}$, as paisagens psicossociais também são cartografáveis. A cartografia, nesse caso, acompanha e se faz a partir do desmanchamento de certos mundos e a formação de novos mundos, que se criam a toda hora para expressar afetos contemporâneos, em relação aos quais os objetos em questão tornaram-se obsoletos. A busca do cartógrafo, independente dos setores da vida social que ele toma como objeto, se realiza sempre na direção do desejo. É importante que o cartógrafo esteja atento às estratégias do desejo em qualquer fenômeno de existência humana que se proponha a pesquisar. Tudo pode alimentar um procedimento cartográfico: um filme, um texto teórico, uma conversa entre amigos, um insight sem explicação aparente. O cartógrafo é um pouco “antropófago" (ROLNIK, 2006, p. 65), vive a devorar e se alimentar de corpos, de qualquer espécie, para em seguida devolver ao mundo outros corpos, novos corpos, reconfigurados. Ele "vive de expropriar, se apropriar, devorar e desovar, transvalorado" (ROLNIK, 2006, p. 65).

Os afetos ganham lugar na dimensão do real, quando apresentados pelo corpo. O caráter vibrátil da presença e das intensidades utiliza a matéria como veículo de expressão. Nesse sentido, a cartografia é um modo de territorializar (corporificar) os afetos, apresentá-los espacialmente, construir realidades. Contudo, essa mesma cartografia, ao lidar com os abismos provocados pelos movimentos incessantes do desejo, precisa a toda hora passar por processos de desterritorialização. Os efeitos da Cartografia se mostram nos encontros entre os corpos e nas reações afetivas de atração e repulsa. Territorializar, para em seguida perder territórios e mais para frente reconfigurar outros novos. Este é um movimento que só um corpo vibrátil e maleável é capaz de realizar.

O entendimento, para o cartógrafo, nada tem a ver com uma explicação ou uma revelação. Para ele não há um "céu de transcendências" (ROLNIK, 2006, p. 66) ou um "abismo de profundidades ocultas"(que Rolnik chama de "brumas da essência"). O que há em todas as direções são intensidades a procura de expressão. Para o alto, para baixo ou para os lados, qualquer que seja a direção, a cartografia deve criar pontes de linguagem que ajudem na travessia daqueles que desejam se

\footnotetext{
9 Todo o desenvolvimento do que se compreende como "cartografia" neste tópico segue a linha discursiva e a argumentativa de Rolink, citada na bibliografia.
} 
aventurar. A linguagem, como ferramenta cartográfica não é um veículo de mensagens ou respostas. O que ela deseja é se colocar, sempre que possível, na “adjacência das mutações" (ROLNIK, 2006, p. 66), fazendo-se reconhecer na tensão entre fluxo e representação. "Fluxo", desordenado de intensidades, caóticas, mutáveis. "Representação", como modo de organização, e em certa medida, como necessidade de atribuição de sentido a essas turbulências.

Falar do "gesto" pela perspectiva da cartografia é reconhecer o caráter finito e limitado do processo de produção de realidade que é o desejo; que se coloca sempre na adjacência das mutações, criando ferramentas que revogam uma constante reconfiguração da paisagem. Durante o processo de levantamento de material para a escrita desta dissertação percebi que algumas atribuições ao gesto eram constantes em textos das mais diversas áreas. Acabei focando nos aspectos que mais me atraíram e construí uma cartografia, uma espécie de mapa de navegação para o leitor, composto por "ilhas informes" cujos territórios se cruzam, se pertencem e se perdem. Se há aqui uma divisão em tópicos que privilegiam certos pontos de vista sobre o gesto, isso ocorre em função da necessidade de iluminar elementos com os quais esta noção se relaciona. A intenção destas passagens não é catalogar ou sistematizar o conceito, e sim propor assuntos para as conversas; roteiros de viagens, que podem mudar da noite para o dia, de acordo com o desejo dos viajantes. Desde já, peço desculpas se algumas discussões se repetirem ao longo dos tópicos, mas as paisagens, aqui, não reconhecem fronteiras e nem pertencem a um lugar fixo. Às vezes, se reencontram onde menos se espera.

"É sempre mais difícil ancorar um navio no espaço". (CÉSAR, ANA CRISTINA, 2013, P. 17).

\section{1}

\section{Gesto e Presença}

CENA 2. APARTAMENTO DE DAVID. DIA. Pela janela, David observa o movimento da rua. Ele é um homem, pequeno, de braços musculosos, de uns quarenta anos talvez. David se chama David, tanto na ficção, quanto fora dela. David, que nasceu sem as pernas, segundo a definição de José Gil ${ }^{10}$ é um monstro

${ }^{10}$ GIL, José. Monstros. Lisboa: Relógio D’Água, 2006. 
teratológico ${ }^{11}$. A repulsa da nossa cultura judaico-cristã pelos “monstros" estaria relacionada a um abalo vertiginoso de uma certa noção de identidade humana, ligada à crença na normalidade do homem. Compreende-se aqui, como corpo "normal”, um modelo de corpo simétrico e saudável, mais ou menos padronizado segundo determinadas normas sociais e constituições fisiológicas. O corpo "normal" nunca está só. Ele vem sempre acompanhado de um simulacro que abarca infinitas possibilidades, dentre as quais, aliás, está incluída o corpo monstruoso. Corpo este, que é do outro, mas que também é possível em mim. O monstro me reflete ao mesmo tempo que me incarna. Um corpo desmembrado como o de David, na cultura judaico- cristã, remete a um corpo doente, incompleto, impotente, um corpo "castigado", digno de pena. E é por isso que ele nos afasta. Ao mesmo tempo, a possibilidade de tornar-se uma aberração, a aventura da experimentação dos extremos do corpo, interessa a mesma cultura judaico- cristã, que promove as mais variadas formas de mutação e a atração pelos Freak shows. E é por isso que este corpo atrai. David é um artista de rua. David-personagem quer ser bailarino, talvez ele até seja. Pode isso? David-intérprete é bailarino profissional (David Toole é seu nome artístico). Pode isso? Pela janela, ele observa duas lindas mulheres, altas, fortes, de longas pernas. Elas o convidam para uma aula de balé. Mas poderá David dançar balé como elas podem? O que pode o corpo de David? ${ }^{12}$

Roberto Côrrea dos Santos apresenta uma formulação que nos interessa: "o gesto é uma potência de vida antes do ato. Às vezes não há ato, só o gesto"13. Antes de mais nada é preciso deixar claro que não estamos aqui nos opondo à ação ou à atividade. Apenas buscamos, inicialmente, a dissociação entre conceitos para dar destaque à "potência", que pode acabar relegada a segundo plano quando atrelada ao conceito de "ato". A breve definição de Côrrea dos Santos para o conceito de gesto, de algum modo provoca as definições de potência e ato ${ }^{14}$, herdadas do pensamento

\footnotetext{
11 A teratologia consiste no estudo de má-formações congênitas, ou seja, de anomalias de desenvolvimento, que provocam alterações no nascimento. Estas podem variar da formação de um ou mais órgãos, até a completa ausência do órgão.

12 Cena livremente inspirada no filme "The Cost of Living", do DV8 Physical Theatre (2005).

13 Definição apresentada oralmente por Roberto Corrêa dos Santos na palestra Vocabulário do Saber Contemporâneo. Conferência do Ciclo Depois do Modernismo. PUC/ Rio, 2012.

14 Principais referências para essa diferenciação presentes no artigo de David Lapoujade, nas correspondência entre Thereza Rocha e Márcia Tiburi e na conferência oral de Peter Pál Pélbart, presentes nesta bibliografia.
} 
aristotélico. Mas que fundamentos presentes nesse pensamento Roberto estaria desafiando? É importante investigar que operações se realizam quando há uma relação de interdependência entre os conceitos em questão. Quando isso acontece, a potência só pode ser concebida como um "ato em possibilidade", um "ato por vir"; enquanto o ato, aparece como a "revelação de uma potência" ao se assumir sob um determinada "forma", a partir da mediação de um "agente". Isso significa que somente depois que um "agente" vivencia um ato é que a potência pode se afirmar como tal.

Um exemplo para clarificar ainda esse ponto de vista: o "agente" bailarino que age realizando um giro revela na "forma-giro" a potência do giro. Sob essa orientação, o ato seria o único meio de desnudar uma potência que poderia passar incólume não fosse a revelação formal. Indo por esta via, um corpo potente é um corpo produtivo, acabado, perfeito e capaz, pois quanto "melhor" a forma do ato, maior a potência que indica. Ou seja, quanto mais ágil e no eixo uma pirueta, mais potente a técnica do seu bailarino. Em outras palavras: o ato significa a potência.

Mas se pensamos que a potência depende do ato, qual é o lugar do devir nos corpos que não atuam com perfeição ou que simplesmente não atuam? O que dizer dos personagens de Beckett, dos gritos de Artaud, do "preferir não agir" de Bartleby? Na obra de Beckett, por exemplo, os corpos se mexem cada vez menos: primeiro, “já é difícil andar de bicicleta, difícil de andar, depois, difícil de simplesmente se arrastar e, depois ainda, de permanecer sentado" (LAPOUJADE, 2002, p. 82). O corpo, como nos aponta Lapoujade, não aguenta mais o ato como legitimação da potência e por isso não se mexe. Isso não quer dizer que não haja potência nos corpos. Todavia, nessa imobilidade está um corpo que de tão parado devém ativo. A inação também promove abalos. Além disso, em Beckett, por exemplo, o corpo vai deixando de ser um corpo "completo", às vezes é só uma cabeça, outras vezes, apenas uma boca que fala. Há, nessas "partes", uma problematização daquilo que se reconhece como "agente".

O gesto rompe a ligação moral entre meios e fins, apresentando medialidades que não necessariamente se destinam a um resultado. Enquanto o ato objetiva suscitar um objeto, o gesto é composto por um aglomerado de razões, vontades, paixões e preguiças que ultrapassam uma distinção entre causa e efeito. "O que caracteriza o gesto, é que nele, não se produz, nem se age, mas se assume e suporta" (AGAMBEN, 2008, p. 12). Se o ato é aquilo que decorre da potência, o gesto não decorre de uma 
outra coisa. Ele simplesmente acontece. Não é que o gesto rompa completamente com a cadeia motivadora dos atos. Ele confunde esta cadeia, para em seguida a retomar e mais uma vez confundir até não encontrar mais o seu sentido. O gesto "se produz e produz alguma coisa a partir dele, e essa coisa vai produzir, produz um outro gesto" (ROQUE, 2013, p. 140).

A técnica desta dança contemporânea com que estamos lidando não está à serviço de um corpo exuberante e de uma movimentação perfeita. Claro que há espaço para isso. No entanto, o que chama a nossa atenção é a possibilidade de se desarticular os estereótipos de um corpo que resiste a clichês de uma significação reconhecida. A fragilidade e a imperfeição do corpo são assuntos da dança, bem como o inacabamento da forma. A dança não tem como objetivo chegar a um destino final. Durante a sua trajetória, sua potência é constantemente produzida e renovada. Mais do que alcançar um corpo perfeito, busca-se possibilidades de caminhos para o corpo.

O que no gesto do corpo dribla a forma imposta ao corpo? No caso da dança, mais do que a perfeição de um giro ou um salto, o que nos interessa são os devires dos corpos, devires esses, "que uma gorda saúde dominante tornaria impossíveis"15. Separamos aqui potência de ato, para dar destaque à vida latente e potente nos mais diversos modos de existir. Não é que não possa haver potência na ação, mas desejamos extrair da aparente impotência, uma outra potência, que desfaz os adestramentos e recusa um corpo fascista. Uns chamam de potência de vida. Outros de energia. Arrebatamento, talvez. Presença.

A noção de presença é fundamental para a discussão sobre o gesto.

Teremos como referência inicial, uma leitura de Gumbrecht (2011, p. 10-19), autor que vem sendo bastante evocado para debater este tema. Gumbrecht faz uma distinção entre "representação", pela via da produção de "sentido" e "representação"16, pelo caminho da produção de "presença".

A divisão, aparentemente binária, entre "representação/sentido" e "representação/ presença" consiste apenas em uma estratégia metodológica da mesma

11 PELBART, Peter Pal. Encontros Provocativos 7/9- Bienal SESC de dança. Conversatório/Convivência - SESC Santos. http://revistapolichinelo.com.br. 12/29/2011. Acesso em $25 / 12 / 2012$.

16 Baseado em Gumbrecth (2001: 10-19). 
natureza da distinção entre "potência" e "ato". Compreende-se que "sentido" e "presença", ao mesmo tempo em que se repelem, também se complementam.

Pensemos na "representação" como a evocação de um objeto ao qual se faz referência, a partir da utilização de um signo, que substitui algo que está ausente espacial e temporalmente. Pela lógica da "representação", o que se coloca em questão é se este objeto ausente é visitado de modo adequado pelo signo, ou se ele é distorcido ou alterado (ainda que a mimeses reconheça de certa forma este processo de alteração). Há uma relação de compromisso com uma referência de "realidade". A representação é o resultado de uma escolha formal, entre as muitas possibilidades da representação da forma. Ainda sob esta perspectiva, o homem é uma extensão da consciência, na medida em que "interpreta" o mundo e atribui significações a ele. O saber sobre o mundo é um saber adquirido pelo sujeito através de atos hermenêuticos. Contudo, o que parece excluído dessa produção e identificação de sentido, se levada ao extremo é aquilo que podemos perceber como a produção de "presença". É o tocante da experiência que foge ao signo e ao significado.

A tal "presença" da qual sempre ouvimos falar ("nossa! esse artista tem uma presença no palco"), ao desafiar a imposição de um ato, desafia também a imposição de uma significação. Ela não significa apenas e nem somente faz sentido. Aliás, talvez seja essa a origem de uma frequente atribuição abstrata, quase que espiritual que se faz a ela. Como se a sua força, por vezes misteriosa e difícil de ser explicada, fosse uma coisa de "outro mundo", que andasse a vagar pelo plano do espírito e de uma hora para a outra se apoderasse de um corpo, passante, ao acaso. Essa noção da presença como um "fora do corpo", é para nós, equivocada, pois ela reconhece o corpo apenas como uma matéria estável e não percebe que o corpo é justo um composto fluido de inconstâncias. Isso não quer dizer que seja um corpo absurdo e irreal, e nem mesmo impreciso. Entretanto, não interessa a ele se adequar a um único corpo, a uma forma fixa ou a uma lógica única.

A perspectiva da "re-presentação", que se coloca como alternativa para a "representação", nos oferece uma escolha de re-presentificação. A re-presentação, segundo Gumbrecht, não é uma representação de algo que se estabelece e permanece ausente, mas a produção constantemente renovada da presença de algo que temporariamente não estava lá. 
"O objeto assim novamente presentificado, neste caso, não é sincronizado apenas com o tempo da percepção de um observador, mas ele é também (e antes de mais nada) presente no espaço deste observador, e se torna tangível para ele. A questão de sentido sobre a (in)adequação da representação de um objeto ausente não pode surgir nessa situação, porque o próprio objeto (por assim dizer, o "original") se torna novamente presente. A representação produz a presença como tangibilidade e não como dimensão do sentido". (GUMBRECHT, 2001, p.11-12)

Para Gumbrecht, o objeto ausente não se coloca como referência, nem como uma memória para o objeto representado. Ele se produz no espaço e no presente, junto com o espectador. É na atualidade do encontro artístico que ele surge e se desenvolve como objeto tangível, mas não como uma forma fixa e estática. $\mathrm{Na}$ cultura da "presença", o sujeito se faz corpo, para além de uma individualidade. O corpo pulsante, constantemente afetado, dilata-se em uma multiplicidade de corpos. A relação com o saber se dá na experiência. Desse modo, a potência ou a presença lidam com as infindáveis possibilidades de ser e não ser, inclusive, com aquelas que não conseguem ser explicadas ou interpretadas.

Quando Gumbrecht nos coloca uma noção de "presença" para além da significação, parece trazer como inquietação, o desejo por uma abordagem da experiência artística ou discursiva, que privilegie as sensações e o tocante da experiência: aquilo que não consegue ser compreendido por atos interpretativos. Entretanto, como dissemos anteriormente, "presença" e "sentido" convivem, em uma relação de oposição e de extrema vizinhança. Só se fala da ausência de sentido, porque já se falou e ainda se fala muito, pela via de extrema valorização do sentido e porque é inegável a manifestação, em certa medida, de uma compulsão interpretativa em todos nós. Todavia é importante ressaltar, que a própria palavra "sentido" pode ser compreendida de três maneiras. A primeira, como explicação e significação. A segunda, pela perspectiva sensorial, como é o caso dos cinco sentidos: tato, olfato, paladar, visão, audição (e por que não um sexto sentido, como o da intuição, por exemplo?). E por fim, o sentido, como orientação, como direcionamento. Sem a pretensão de se chegar a um lugar definitivo, colocamos a seguinte questão: de que maneira "sentido" e "presença" se relacionam com essas três possibilidades da palavra?

Gumbrecht aponta para o caráter vibrátil de um corpo que não se refere apenas a si mesmo, mas à uma presença dilatada. Ao colocar seu foco na espacialidade, desarticula uma compreensão quase essencialista do homem, mais vinculada à temporalidade (sincronia), na qual a "presença" aparece como um 
instante "agora" no qual $o$ corpo passa por uma espécie de combustão da potência, ao encontrar-se na mais justa medida "consigo mesmo". Esse encontro com um corpo que se apresenta "diante de nós" no invisível ponto do tempo presente se orienta a partir de uma ideia de unidade, como se aquela individualidade convergisse para um só ponto, material e visível e chegasse à forma e à essência máxima de "si" naquele instante. Mas afinal de contas, qual será a mais justa medida do encontro de um corpo "consigo mesmo"? Quando à ideia de uma identidade vinculada a um "eu" se vê abalada e pulverizada (pelo menos na Filosofia e na Arte), essa concepção de "presença" deixar de fazer sentido.

Jean-Luc Nancy (2013, p. 115-121) também questiona a presença como algo que se produz através de uma materialidade maciça "colocada" diante de nós, e introduz um novo olhar, no qual a presença aparece como uma "manifestação". Neste pensamento, que muito nos interessa, dentro do qual o corpo aparece como um caos sensível, expandido e em desequilíbrio; a presença desloca-se da sucessão temporal dividida cronologicamente entre passado, presente e futuro. Não é que a presença não estabeleça nenhuma relação temporal, mas o "presente", deixa de ser um marco localizável e apreensível. Não é possível viver o presente, visto que ele não se retém, não se esgota e é substituído por outro "presente" logo que se atualiza. A “presença", proposta por Nancy, lida com o efêmero na medida em que afasta os efeitos do Tempo (pelo menos do tempo sequencial) e aproxima-se do espaço.

A "presença" é aquilo que irrompe o espaço e de alguma maneira provoca uma surpresa. Ninguém sabe como ou porque aquilo aparece, mas aparece de modo incontornável. A partir desta percepção de "presença" a noção de unidade não se sustenta, pois esta é uma noção que só pode ser compreendida através de um corpo em relação de dilatação e transformação. Por isso a presença não toca a todos da mesma maneira. É possível que uns a sintam em um determinado encontro e outros não. Ela não pertence somente a uma ou a duas pessoas. É algo que só se estabelece a partir um conjunto instável e variável de relações. E o que ela produz não é um indivíduo no máximo da sua essência, na sua mais "justa medida", mas afetos em múltiplas direções.

A "presença" é sempre uma "presença à". Como uma apresentação: algo ou alguém que se apresenta a algo ou alguém. E o que essa apresentação demanda é um gesto efêmero, subtraído do curso do Tempo. 
"Cette présence comme $<<$ présence à $>>$ demande un geste, et ce geste-lá est soustrait au cours du temps et, en un sens, il est éphémère. Mais cette non-durée est en même temps quelque chose qui imprègne la durée elle-même ${ }^{17}$ ". (NANCY, 2011, p. 117)

O gesto se estabelece na experiência entre artistas e público, entre artistas e tema, entre público e sociedade, entre linguagem e impossibilidade de dizer, além de muitas outras relações. Tem a ver com os afetos de um encontro. É aquilo que nos toca de maneira diferente a cada dia de apresentação ou de observação de uma obra, sem que saibamos dizer "no fundo, no fundo", o que é que nos toca ou porque. É o indizível do encontro entre eu e um outro. Às vezes, vemos dois artistas executando um ato semelhante, como uma mesma sequência de movimentos, por exemplo, mas somente um deles nos desperta pela "presença à". Isso se dá pelo fato da presença não ser uma qualidade fixa, não ser algo que se possa reter entre as mãos. $O$ gesto que se realiza nos lembra que tudo passa, nada dura, visto que não é possível reter um só corpo a um só tempo. Todavia, essa sensação de finitude diz respeito a alguma coisa que permanece. A presença que "apresenta" coloca a atenção sobre algo que até então não estava lá. O efêmero do gesto que lida com um porvir é, simultaneamente, eterno e passageiro. Como uma borboleta, que quando sai do casulo vive um dia e morre. Depois, outras borboletas vêm e vão.

\begin{abstract}
"Nous nous trouvons donc dans l'ordre des éphémèrides, ce à quoi en général nous sommes très peu attentif: la succession des jours a pour elle quelque chose de cosmique, de cosmologique et c'est aussi la sucession de la reprise $<<$ quotidienne $>>$, d'une façon de venir au monde. Tous les matins, on revient au monde après un véritable absentement dans le sommeil, lié à cette pauvre vérité phycologique, biologique: sans sommeil, on ne peut vivre longtemps." (NANCY, 2011, p. 117) ${ }^{18}$
\end{abstract}

Este breve instante que não se retém, mas que provoca um impacto, lida com o movimento de dormir e despertar. O gesto provoca uma renovação, como o sono. Uma renovação do olhar, de uma atitude, de uma condição, de um modo de viver, de se colocar e que só é possível a partir de uma presença.

\footnotetext{
17 Tradução minha: "Essa presença como <<presença à $>>$ demanda um gesto, e esse gesto subtraído do curso do tempo é, em certo sentido, efêmero. No entanto, essa não duração é alguma coisa que é impregnadada da duração ela mesma".

18 Tradução minha: "Nós nos encontramos, portanto, na ordem das efemérides, algo a que em geral somos muito pouco atentos: a sucessão dos dias tem por ela mesma alguma coisa cósmica e é também a sucessão da retomada $<<$ cotidiana $>>$ de um modo de vir ao mundo. Todas as manhãs, nós viemos outra vez ao mundo, depois de uma verdadeira ausência que se estabelece no sono, ligada a essa pobre verdade psicológica, biológica: sem o sono nós não conseguimos viver por muito tempo".
} 
Enquanto escrevia este tópico, fui lembrando daquela fábula da Roupa Nova do Rei. Era uma vez um rei que queria uma roupa nova, uma veste maravilhosa. Então, veio um falso tecelão e disse ser capaz de costurar com tecidos e linhas invisíveis a roupa mais leve e fina do mundo. A verdade é que o trambiqueiro entregou ao rei uma caixa vazia, dizendo que no seu interior estava um manto nunca antes visto e que, por ter sido bordado em tecido fino, só poderia se enxergado por homens inteligentes e de bom gosto. Assim, tanto o rei quanto os súditos alegaram ver a roupa para não se passarem por estúpidos. O rei, ao "vestir" a roupa, desnudavase perante o reino e sua postura física se alterava para conformar-se à imponência da veste ausente. $\mathrm{O}$ rei pelado se empinava majestosamente, estufava o peito. $\mathrm{O}$ povo, diante do corpo nu do seu superior, arregalava os olhos e elogiava sua magnificência. Um dia o Rei subiu com sua veste especial no palanque para dar um pronunciamento qualquer. Do meio da multidão, um menino simples, filho de camponeses, grita: “o rei está nu!” e assim revela ao Rei e a os súditos o óbvio até então oculto.

O gesto é como a roupa nova do rei. É uma força variante, invisível, impalpável, difícil de ser descrita, mas que atua sobre o corpo e a partir dele, promove abalos em modos de existir. A roupa ausente se faz extremamente presente pela potência da sua falta. Só há presença porque há ausência, mas não como um paradoxo. Aliás, o gesto coloca em questão justamente esse ponto em que ideias aparentemente opostas coabitam. O que a fábula mostra, a partir desta nossa leitura é que a presença não necessariamente tem a ver com a materialização de um objeto formal. A potência da presença, que também podemos chamar de "força", se faz visível, na carne do homem. Os corpos presentes e ausentes da fábula tornam visíveis forças invisíveis. A roupa presente-ausente desnuda o corpo civilizadamente coberto. Reconhecemos na fábula uma denúncia aos jogos de poder e às convenções discerníveis. Quando o menino grita o que ninguém quer ou consegue ver, desmascara a convenção estabelecida pelo acordo de uma linguagem comum imposta pela instituição dominante. O gesto do menino, que revela a nudez, revela igualmente a estupidez do acordo até então não questionado, entre o Rei estúpido, e a sua plebe.

O gesto é o ponto intensivo que encontramos na linguagem, mas que rompe com uma linguagem representativa. Ele é a força que desestabiliza a formalinguagem. O gesto consiste em arranjos de intensidades que despertam sensações e reflexões. Mas não uma reflexão estática, hermenêutica. É a partir das intensificações de regimes sensíveis que uma nova linguagem se cria. E essa "nova" linguagem que 
se configura é uma linguagem de uma outra ordem. É uma língua interrompida de si, da sua interioridade, dos vícios, dos automatismos, das resignações, dos acordos nãoquestionados. E essa interrupção só é possível, porque é a partir dela que algo se inicia, como uma língua prestes a nascer, que ainda não se conhece, que gagueja, que está sendo criada, e que vê o mundo com espanto e curiosidade. Como estamos falando de dança, não se trata só de uma forma única ou de um movimento perfeito. Também não é o caso de simplesmente tentar atribuir significado a uma determinada postura ou associar o objeto artístico a um objeto ausente. O que importa ao gesto, produtor de potência, produtor de presença é aquilo que no movimento-ato-formalinguagem nos provoca arrepios. É também aquilo que torna tangível (seja em palavras, em sons ou em cores), o "imaterial." É o que tenta a todo custo dizer o indizível, mesmo sabendo, em algum lugar que isso não será possível.

\section{2}

\section{Gesto e Experimentação}

SEQUENNCIA 3. CASA DE MARIA HELENA. TARDE. Maria Helena tem vinte anos. É sexta-feira e ela passa seu uniforme de garçonete com mais cuidado do que de costume, como se pressentisse algo de especial para a noite. Um vestido bem curto com a logomarca do bar. A moça gosta de mostrar as pernas. CORTA PARA: BAR DO PORTO. NOITE. Um marinheiro senta no balcão e pede um copo com gim. Pede outro e mais outro. Ele se encanta com a beleza da atendente. Ela se apavora diante do desejo que sente pelo rapaz. Quando o bar fecha, os dois vão para o quarto de Maria Helena em uma pensão que cheira a mofo e naftalina. Titus, o marinheiro, retira a roupa de Maria Helena com brutalidade e paixão. CORTA PARA: CASA DE MARIA HELENA E TITUS. DIA. Maria Helena pega a roupa embolada do chão. Veste-a de novo, mas curiosamente, no momento em que torna a vestir, a roupa apresenta outra textura. Maria Helena, com esta nova roupa tem mais ou menos 40 anos. Casada, com o ex-marinheiro, Titus, a mulher folheia uma revista velha, enquanto o marido assiste a uma partida de futebol na televisão. Maria Helena sonha com lugares distantes, com futuros insuspeitados. Sua cabeça navega pelos mares que Titus abandonou. Ela sente na própria roupa um cheiro de roupa molhada, que não secou direito no varal. Decide trocá-la. Vai até o banheiro e mais uma vez a roupa cai no chão. CORTA PARA: CASA DE MARIA HELENA E TITUS. 
NOITE. A roupa é novamente apanhada, com uma aparência completamente diferente das duas que a precederam. Maria Helena a veste e agora tem oitenta anos. A roupa é toda de lã e ajuda a proteger do inverno rigoroso. Depois de um mês, CORTA PARA: BASTIDORES. Acabam as filmagens deste projeto. A figurinista recolhe as roupas que em breve vestirão outros personagens. As que não servirem para outros trabalhos, serão repassadas aos brechós e compradas por desconhecidos. Cada vez que for vestida, a roupa apresentará uma nova composição, uma nova textura, uma nova cor. ${ }^{19}$

O gesto não é aquilo que acontece, ou seja, não é a somente a forma "roupa" ou ato de se vestir. "Ele é no que acontece, o puro expresso que nos dá sinal e nos espera" ${ }^{20}$ (DELEUZE, GILLES, 2011, p. 152). O gesto está muito mais ligado ao modo de fazer do que ao fazer propriamente dito. É muito mais da ordem da experimentação do que da significação de elementos por um único sentido. A relação com o "como" conta muito mais que o resultado, a consequência ou a funcionalidade de uma ação. Por isso, mais do que se dirigir a um fim, "o gesto é a exibição de uma medialidade, o tornar visível um meio como tal” (AGAMBEN, 2008, p.13). A dimensão ética está em mostrar o homem no meio de si, no meio de seu processo. O gesto privilegia a aparição dos materiais: a forma, a cor, a imagem, a palavra, o movimento, o som, os corpos. De algum modo esbarra na metalinguagem, pois faz referência ao próprio fazer, ainda que isso possa se dar de infinitas maneiras. A partir da explicitação das materialidades, o gesto nos lembra que aquela experiência é apenas uma das combinações possíveis a serem feitas com determinados materiais, e que se estes fossem combinados de maneiras diferentes poderiam compor outros elementos, criar outros mundos.

O gesto carrega uma carga expressiva, que atribui diferença à cada forma, à cada atividade. Ele nos revela a ausência de uma natureza pura. Não há ponto de chegada, mas trajetória e arranjos. Esse lugar de testagem do gesto, que não se conclui em nenhuma resposta marca o seu caráter variável e informe, na medida em que não se fixa unicamente à sua própria materialidade. Tudo o que há é uma busca por ferramentas de existência e modos de fazer. O corpo do gesto é sempre desconhecido, nunca encontrado. Se ele se materializa a partir de alguma forma, é

19 Cena livremente inspirada no filme "Valse Wals", do Grupo Orkater (2005) e na fala de Deleuze sobre Ricardo III, p. 48, 2010.

20 Grifo meu. 
porque precisa de um contorno para se revelar. Mas aquilo que se coloca é apenas um contorno possível para falar de muitos corpos. É apenas uma entrada, que não se encerra em um lugar fechado. “Todas as entradas são boas, desde que as saídas sejam múltiplas" (ROLNIK, 2006, p. 65). Quais são as entradas e as infinitas saídas na busca pela materialização do desejo? Esta é uma pergunta proposta pelo gesto.

As artes do palco deixam bastante clara a relação com a variação, visto que o discurso se atualiza sempre a partir do encontro e que cada dia de apresentação é diferente do outro, ainda que algumas características se mantenham. O tempo é uma forma de repetição, marcado por diferenças infinitas. Diante de um tempo que se diferencia indefinidamente, nada pode conservar uma forma estável. Logo, não é possível passar duas vezes pelo mesmo gesto sem a obtenção de características diferentes, visto que a forma é sempre deformada pelas variações de afetos e velocidades. O que interessa ao gesto é a força transformadora, o movimento de passagem de um estado ao outro, mas que não chega nunca a ser somente um estado ou somente o outro.

\footnotetext{
"Deste gosto a este desejo, nada muda de uma certa maneira, salvo uma mudança de vontade, uma espécie de salto no próprio lugar de todo o corpo que troca a sua vontade orgânica por uma vontade espiritual, que quer agora exatamente não o que acontece, mas alguma coisa no que acontece, alguma coisa a vir de conformidade ao que acontece". (DELEUZE, 2011, p. 152)
}

O performer não chega nunca a efetuação do ato em si. Se ele encena uma situação de morte ou amor, o que coloca sobre o palco não é apenas a morte ou o amor à que se refere, mas uma variação das múltiplas possibilidades de se abordar um tema. "O gesto transforma um fato num acontecimento; ele se basta, como na dança é um meio sem finalidade.” (PÉLBART, 2003, p. 69). O artista da repetição, ao tentar repetir o irrepetível, ao tentar efetuar o que não pode e nem poderá ser novamente efetuado, lida com a arte e com a vida pela perspectiva da artesania, valorizando muito mais as ferramentas de construção e composição do que a entrega de um produto final. 


\section{3}

\section{Gesto e Ruptura}

CENA 4. SALA DE JANTAR. NOITE. Dez convidados em torno da mesa. Alguns estão sentados, outros de pé. Todos muito bem vestidos. Seus corpos são esguios. Poderia dizer que são bailarinos, jovens e saudáveis. Lindos. Todos sorriem educadamente. Não demonstram tédio, nem ultrapassam os limites da euforia. Esperam o banquete, felizes e pacientes. A garrafa de champanhe gela no balde. Os talheres devem ser utilizados de fora para dentro, seguindo a etiqueta. Hoje é o aniversário do patriarca. O patriarca está morto, mas comemoram seu nascimento mesmo assim. Sobre o que será que conversam? Será que se escutam? Ao longo da cena esvaziam as garrafas. Um pequeno salto temporal. Pronto. O cenário se mantém, mas agora os convidados riem escandalosamente, gargalham, batem palmas, seus olhos estão menores. Efeitos do álcool. Ultrapassam os limites. Arrotam, emitem grunhidos. Um homem tira um rato do bolso e o agita sobre a mesa, mas não escutamos gritos de pânico. Pelo contrário. $O$ homem leva o rato em direção aos lábios da sua esposa, que o beija com vontade. Os corpos dos convidados quase tombam para fora da cadeira. Estão tontos. Enjoados. Uma moça sobe na mesa e conta uma história em um idioma que não entendo. Acho que é alguma língua do Leste Europeu. Desconfio que seja grego, mas não posso afirmar com nenhuma certeza. Os convidados urram. Oferecem à estrangeira um coquetel, que ela bebe em um só gole. Parece nauseada. Os homens batem com os punhos no tampo da mesa. Estão muito bem vestidos. Escutamos uma música, acho também que é uma canção grega, os passos da dança me lembram os de Zorba. Uns sobem nos pratos, de sapato e tudo, enquanto outros tentam se equilibrar sobre os copos. E isso não é uma metáfora. Um mulher quer desmaiar. Não há mais ninguém sentado em volta da mesa da maneira que estamos acostumados. Que etiqueta? A música acaba. Silêncio. Homens e mulheres erguem as taças e quebram os vidros com as mãos. Corta para EXTERIOR/ DIA/ UMA FLORESTA TROPICAL ALUCINANTE. Os convidados espalhados pela paisagem paradisíaca. Os mesmos, lindos e esguios. E agora eu confirmo: são bailarinos. No meio do mato, longe da civilização, dos jantares da burguesia, rasgam as roupas de festa. Se sujam de lama, mergulham nos rios. Viram pedras e porcos. Desejam devorar os outros corpos como predadores ou animais no cio. Os movimentos são feios e belos. Humanos e inumanos. Danças e 
erros. Os lindos bailarinos também metem medo. Eles urram, se tacam no chão. Longe de casa, os convidados lembram que são animais. Tornam-se outros, sem deixar de serem aquilo que são ${ }^{21}$.

Todo gesto provoca uma ruptura ou uma cisão, como a paixão, uma ferida ou a morte. $\mathrm{O}$ gesto abre em nós um abismo que nos divide entre aquilo que éramos e um estado de "devir" (porque do outro lado do abismo não chegamos a ser de fato uma outra coisa, nova e estável). Este abismo é o que somos? Através de um gesto alguma coisa se rompe.

$\mathrm{O}$ teatro de Bertolt Brecht lida bastante com a ideia de "quebra". Na dramaturgia épica a noção de gestus atua pelo princípio de descontinuidade sobre uma fábula. Descontinuidade essa que rompe com o ilusionismo naturalista, desarticula o fluxo dos acontecimentos e abre espaços para comentários, levando o espectador a assumir uma atitude de observação crítica. Neste contexto, o personagem não é abordado sob uma perspectiva psicológica, nem sua fisicalidade pode ser interpretada como a tradução de uma interioridade. Na interrupção de uma narrativa linear dramática, o teatro épico se mostra como teatro e não como um espaço "mágico" que significa o mundo. O corpo do ator, a fala e a cena se apresentam pela metalinguagem como materiais que se articulam em uma construção discursiva, marcando um mundo que é completamente tomado por discursos, o tempo todo.

As rupturas provocadas pelo gesto podem ser percebidas na proposta brechtiana a partir de diversos procedimentos, como por exemplo: a interrupção da linearidade dramática (em cenas que de alguma forma não dependam como causa da cena seguinte, nem consequência da cena anterior, para serem "compreendidas"), quebra da quarta parede (onde o ator se relaciona com seu público e se dirige a ele para comentar os acontecimentos), inserção de recursos audiovisuais ou cartelas com títulos e palavras; entre outros.

Walter Benjamin (2011, p. 78- 90), em seu artigo sobre Brecht, aponta para algumas características do gesto. Em primeiro lugar, o gesto é pouco falsificável e ilusionístico, sobretudo, quanto menos habitual e mais distante do naturalismo. A relação do ator com o seu personagem não se articula a uma tentativa de dar conta dos

21 Cena livremente inspirada no filme "Blush", de Win Vanderkeybuys (2011). 
sentimentos e estados psicológicos propostos pelo drama, no sentido de uma fusão que torne o ator idêntico ao seu personagem. Mais do que isso, o ator deve encarar seu personagem com certo distanciamento, manipulá-lo como um instrumento, pensar em cada movimento, em cada gesto, refletindo sobre os efeitos que essas escolhas terão sobre seu público. $\mathrm{O}$ ator não tem como intuito iludir o público, mas compartilhar com ele que aquela experiência teatral se trata de uma criação. Por isso seu corpo precisa romper com uma "normalidade" naturalista, que tenta imitar as posturas da vida cotidiana, em tempo integral e ser atravessado por corpos "estranhos", não cotidianos ou convencionais. O estranhamento provocado pelo gesto nos afeta de modo reflexivo. Além disso, o gesto deve ter um começo e um fim determináveis, não seguindo um encadeamento causal. A ação deve ser sempre interrompida, nunca ilustrada.

"Quanto mais frequentemente interrompemos o protagonista de uma ação, mais gestos obtemos. Em consequência, para o teatro épico, a interrupção da ação está em primeiro plano". (BENJAMIN, 2011, p. 80)

A obra é posta em questão, bem como o mundo em que a obra se insere. Contudo, para promover uma ruptura, a desarticulação deve ser feita sempre na esfera do possível. Somente um gesto minimamente reconhecível e familiar nos interpela a olhar para a o presente da nossa realidade - aquela que vivemos e nos confrontamos diariamente - sob uma nova perspectiva. Mesmo que o gesto soe estranho, ele precisa ser provável, pois só assim somos tocados pessoalmente, intimamente.

Para Brecht, a mais alta realização do ator é tornar os gestos citáveis. O teatro episódico visa uma reflexão dialética sobre o mundo em que se vive, como se constantemente nos deparássemos com os abismos da nossa sociedade e fôssemos obrigados a adotar uma postura crítica diante deste precipício. Deste modo, a descontinuidade provocada pela ruptura não permite o embalo, de modo alienado, pelo fluxo dos acontecimentos. Ela faz a existência "abandonar o leito do tempo, espumar muito alto, parar um instante no vazio, fulgurando, e em seguida, retornar ao leito" (BENJAMIN, 2011, p. 90). É o efêmero não-cronológico sobre o qual começamos a falar.

Apesar da contribuição fundamental de Brecht para este conceito, ele ainda aparece muito vinculado a ideia de Fábula. Atualmente, o gesto na dança e no teatro, já pode ser pensado para além de uma reflexão racional de construção de sentido 
sobre uma narrativa dramática. O gesto, que interrompe, atua por uma explosão de imagens, não necessariamente racionais e reconhecíveis pela linguagem das palavras e do drama. Então, por que não aliar esta abordagem brechtiana, na qual o gesto aparece como um sobressalto que interrompe o fluxo narrativo, aos olhares de Artaud e Grotowiski, que focam mais na "presença" do corpo do atuador, do que em uma visão dele como um suporte de signos? Ambos os autores, deixam como reflexão para futuras produções das Artes Cênicas a ideia de que a linguagem dos gestos não deve ser uma construção inteligível e nem precisa necessariamente passar por uma racionalização discursiva. Ela deve, antes de tudo, agir em função da produção de um corpo e da manifestação da sua energia.

O hiato de onde emerge a "presença" é decorrente do confronto entre elementos discordantes. "Do ponto de vista da cultura da presença, o conceito de evento (...) deve resultar dos contrastes dos 'eventos' em relação às regularidades cosmológicas constantes" (GUMBRECHT, 2001, p. 13). Na dança, só há gesto onde há, em certa medida, um desacordo: entre corpos diferentes, entre um movimento e um discurso, entre dimensões espaciais, entre dinâmicas de velocidade, entre representação e não-representação e todas outras combinações conflitantes possíveis. Esses elementos atuam como vetores de força, que "puxam" para direções distintas, mas não necessariamente diametralmente opostas. A tensão dos vetores sobre os corpos onde se instaura o gesto é tão insuportável, que sendo explorada no seu limite acaba por "rasgar" o corpo. Talvez por isso o gesto é muitas vezes confundido com movimento ou ação. Não é rara a referência a um verbo quando se tenta definir o gesto. Como o gesto "toca" diretamente o corpo, podemos ter a sensação que ele movimenta alguma coisa. Essa ruptura afeta de tal forma a carne que alguma coisa parece deslocar-se. Contudo, o movimento que ocorre é de outra ordem, podendo ser imperceptível aos olhos. Não é um movimento no sentido de uma ação produtiva. Ele mexe com impulsos e afetos, que podem não ser facilmente notados. É uma vida que chama a atenção para a própria vida.

\footnotetext{
"Penso numa possível distinção entre movimento e gesto. As estrelas, o sistema solar, os planetas, se movimentam, uma máquina, um trem se movimenta. $\mathrm{O}$ gesto é humano, é um gesto em relação, é alguma coisa que sai de mim e que integra alguma dimensão simbólica e concreta". (SOTER, 2013, p. 93)
} 
O gesto é como uma marca, não uma marca fixa, mas uma cicatriz móvel que rasga o tecido da pele e está sempre pronta para rasgar novos tecidos, deixar sua marca em outros corpos. Nesse sentido, ele não pertence somente a uma identidade individual, apesar de nos tocar intimamente. É aquilo que, diante de um acontecimento nos desestabiliza - tanto como artistas, quanto como espectadores -e faz com que, em vida, morramos um pouquinho de nós.

\section{4}

\section{Gesto e Multiplicidade}

CENA 4. DIA. RUA. Um homem vestido de blazer preto e óculos escuros (SENHOR X.) segura uma câmera digital. Ele tenta filmar o bailarino David, da SEQUÊNCIA 2. DAVID procura se desviar da câmera. Anda com os braços de um lado para o outro. Quer ficar sozinho. Senhor X fala: "Você nasceu sem pernas ou elas foram cortadas?" David se esquiva. Senhor X continua: "Você tem ânus ou defeca em uma bolsa? Você culpa Deus por ter nascido? Como você vai ao banheiro? Pode se masturbar? Você tem amigos? Já entrou em uma briga?". David vira o rosto, respondendo: "eu não confio em você". Senhor X vai embora. David sobe uma ladeira, caminhando com os braços. Mas não está sozinho. Atrás de David, dez homens vestidos com o mesmo macacão o seguem. Esses homens formam um coro do qual David se destaca como corifeu. O tronco dos onze homens pendula de um lado para o outro. Todos "dançam" uma caminhada. Os membros do coro não utilizam as pernas que possuem, mas pouco importa. Cada um caminha com os braços que têm. Uns são mais altos que outros, uns mais gordinhos, uns brancos, uns negros, uns orientais. Homens e mulheres. David se vira para o público e diz: "você quer dançar? Não fique com vergonha. Talvez queira um drink, algo que te ajude a relaxar, talvez outra coisa. Talvez queira a mim. Ou talvez só os meus braços. Pode imaginá-los ao teu redor? Com as pernas não posso. A única coisa boa sobre elas é que vêm em pares. Eu sei... Pode ser o ânus...aposto que te perguntas: como ele é? Bom, eu digo. É pequeno, mas intimida. Te vejo olhando." Todos são David.. ${ }^{22}$

${ }^{22}$ Cena livremente inspirada no filme "The Cost of Living”, do DV8 Physical Theatre (2005). 
O gesto não pertence somente a um indivíduo. Também não se conecta a uma identidade fixa. A imagem da roupa mutável vista na "Sequência 3" aponta para a mobilidade do gesto. Como uma roupa que se retira e se coloca, o gesto pode vestir infinitas pessoas, infinitos corpos. Ele não reconhece limites de tamanho ou estilo.

O bailarino, quando trabalha, tal qual um ator, despe-se, em algum nível da sua identidade social, mas não chega a se fundir completamente com a forma que dança ou a uma figura ou personagem que evoca. Ao longo do século XX, a concepção de personagem ligada a uma identidade construída, é completamente abalada. Podemos ainda, hoje em dia, falar em personagem? O que a ideia de personagem significa para nós? Como personagem e intérprete se relacionam e se distanciam? Como trabalhos tidos como "auto-ficção" ultrapassam os limites da identidade a que parecem se referir? Essas são questões muito frequentes para a arte contemporânea.

Ao desempenhar um papel ou uma ação, o performer encena todas as probabilidades de troca de papéis, todas as possibilidades e impossibilidades do corpo de ser outro, de refazer-se outro.

"O que ele (o ator) desempenha não é nunca um personagem: é um tema ( o tema complexo ou o sentido) constituído pelos componentes do acontecimento, singularidades comunicantes efetivamente liberadas dos limites dos indivíduos e das pessoas". (DELEUZE, 2011, p. 53)

Assim como o tema da morte, o gesto é aquilo que me toca no que há de mais íntimo. Quando estamos diante de um arrebatamento ou da solidão, por exemplo, a sensação é de estarmos atravessando uma experiência única. Ao mesmo tempo esta experiência diz respeito ao incorporal e ao impessoal que não pertence a mim, nem a ninguém. Lida com o comum. Como a morte, não é um assunto somente privado ou só coletivo, o gesto não é nem individual, nem universal.

A dança toma de empréstimo a linguagem dos corpos para emprestá-la a outros corpos. Um gesto nunca é só meu ou só de um outro, por mais que assim ele pareça. Isso ocorre muitas vezes porque o arrebatamento diante de uma obra se dá naquilo que é extremamente singular, que só parece possível naquele encontro, mas que pertence a uma multiplicidade dos afetos e percepções. Singular é diferente de individual. Como uma paixão; que a cada vez parece única, mas que se inscreve (e nós sabemos) na experiência de tantas, tantas outras paixões. 
Há na dança um forte desejo pela experiência comum, mas não como unidade indivisível, não como formação de um bloco homogêneo ou uma instituição da mesma natureza. O que está em jogo é a possibilidade de se celebrar a união das diversidades, das faltas, das falhas e das incoerências. A alegria de dançar em conjunto apresenta no passo comum uma ideia que se estende para além da própria dança. Dançar junto é também caminhar junto, fazer parte de uma multiplicidade.

"On danse, le plus souvent, pour être ensemble. On se met à plusieurs. Les corps s'approchent les un de autres, vont et viennent sans ordre préétabli mais avec la même obstination dans le tour et le retour. Ils se frôlent, se frottent, se désirent, s'amusent, se déchaîne. C'est une fête. (DIDI- HUBERMAN, 2006, p. 9) ${ }^{23}$

O gesto, ao evocar o "comum”, desarticula a noção autoria. Quando o gesto se faz presente, sobretudo na arte, o traço se torna mais importante que a assinatura. $\mathrm{O}$ que interessa é o traçado no espaço. Um traço que apesar de um dia ter sido feito por alguém (ou por uma coletividade) já não pode ser atribuído a uma identidade única. Assinatura é aquilo que se deixa em um cheque, em um contrato, em uma sentença. $\mathrm{O}$ traço é uma marca, denota um estilo. Claro, muitas vezes associamos um gesto a um autor. Talvez por uma necessidade tão entranhada em nós de dar nome às coisas, de torná-las localizáveis. O que interessa, sob a concepção do gesto, em Duchamp ou em Andy Wharol? Suas biografias, seus nomes próprios ou aquilo que abalaram? Os traços marcam uma presença, muito específica, mas não uma individualidade.

\section{5}

\section{Gesto e Temporalidade ${ }^{24}$}

Ria e Titus já perderam a conta da própria idade. Os cabelos são brancos e ralos. Os ossos estão fracos. Juntos, decidem começar a despedida. Saem de casa, cansados. Arriscam-se pelas ruas da cidade que não para de se transformar, dia após dia. A cidade cresce. Mas em que direção? Os carros em alta velocidade, as

\footnotetext{
23 Minha tradução: "Nós dançamos, a maior parte do tempo, para estarmos juntos. Nós no colocamos entre vários. Os corpos se aproximam uns dos outros, vão e vêm sem uma ordem pré-estabelecida, mas com a mesma obstinação nas idas e vindas. Eles se roçam, eles se esfregam, se desejam, se divertem, se rompem. É uma festa".

24 Os parágrafos desse tópico apropriam-se do modo como Deleuze constrói o conceito de "Acontecimento" na sessão "Do Acontecimento", de "A Lógica do Sentido".
} 
baldeações labirínticas das linhas do metrô. Ria e Titus arrastam-se, pendurados um no outro. A rua por onde caminham... Será a mesma de cinquenta anos atrás? Ou é uma nova rua com o mesmo nome e no mesmo lugar? Titus e Ria não reconhecem quase nada. Mas alguma coisa lhes é familiar. Caminham mais do que aguentam as próprias pernas. Fazem amor pela última vez embaixo de uma marquise. E depois de horas, chegam, enfim na praia na qual o navio de Titus atracou há muitos anos atrás. O frio é de congelar os ossos. Caminham com os pés na borda do mar. Titus tem um ataque cardíaco fulminante. Cai duro e morto na areia. Ria nem olha. Segue sozinha, como sempre foi ${ }^{25}$.

\begin{abstract}
"O ator não é como um deus, antes seja como um contradeus. Deus e o ator se opõem por sua leitura do tempo. O que os homens captam como passado ou futuro, o deus o vive no seu presente. O deus é o Cronos: o presente divino é o círculo inteiro, enquanto que o passado e o futuro são dimensões relativas a tal ou a tal segmento que deixa o resto fora dele. Ao contrário, o presente do ator é o mais estreito, o mais cerrado, o mais instantâneo, o mais pontual, ponto sobre uma linha reta que não cessa de se dividir a si mesmo em passado-futuro ilimitado que se reflete em um presente vazio não tendo mais a espessura de um espelho. $\mathrm{O}$ ator representa, mas o que ele representa é sempre ainda futuro e já passado, enquanto sua representação é impassível e se divide, se desdobra sem se romper, sem agir nem padecer. É neste sentido que há um paradoxo do comediante: ele permanece no instante, para desempenhar alguma coisa que não para de se adiantar e de se atrasar, de esperar e de relembrar". (DELEUZE, 2011, p. 52)
\end{abstract}

Como vimos anteriormente, aquilo que o artista cênico desempenha não se encerra somente no indivíduo, pelo contrário é um assunto que concerne a todos, de um jeito ou de outro, mesmo que toque cada um em um ponto diferente da percepção e da afetividade. Sendo assim, a relação temporal também não se conecta à apenas uma época e nem passa pela atribuição de um valor histórico à uma realidade. $\mathrm{O}$ gesto foge à linha do tempo intempestivo e sequencial. Escapa ao processo dialético em geral. Mesmo que em termos narrativos, a coreografia ou a encenação se articule a um período específico e faça referência a uma época, seja através de um tema de referência, uma trilha sonora ou um figurino, o espaço e o tempo evocados são sobretudo, recursos que funcionam como mediadores de afetos.

Uma situação muito recorrente que pode nos servir de exemplo é quando o público, diante de uma obra composta há mais tempo ou que se relacione com um contexto anterior diz: “nossa, isso é tão atual!" ou então "esse artista estava tão à

${ }^{25}$ Cena livremente inspirada no filme "Valse Wals", do Grupo Orkater (2005). 
frente do seu tempo!”. Mas como é possível estar à frente de um tempo? Do seu tempo? É importante perceber que a sensação de atualização provocada pelo gesto não diz respeito a um "antes" que ainda faz sentido "hoje" ou que o artista é um profeta capaz de prever o futuro. Se falamos em "passado, presente e futuro", o fazemos simplesmente por não termos outro vocabulário para tratar de certos posicionamentos diante da passagem do tempo. A sensação de que uma obra é em certa medida, atemporal, ou seja, de que ela não se prende a um tempo exclusivo, só se estabelece em trabalhos de artistas extremamente conectados à sua época. O que Pina Bausch, Isadora Duncan, Martha Graham, Ninjinski, Win Vanderkeybuys, Ana Teresa de Keersmaeker, Beckett, Artaud, Heiner Müller, Grotowiski, Brecht, Kantor, e tantos outros artistas da cena e de outras áreas produziram e deixaram para nós, senão reações às indagações da sua época? Reagir ao seu tempo talvez seja a única maneira de romper com os limites de uma data ou um período. Mas como falar da sua época sem ser datado? Como dialogar com as forças que o atravessam sem precisar dar conta da reprodução e descrição "fiel" do seu contexto?

O gesto é justo a suspensão que provoca uma interrupção no tempo cronológico. Isso não significa que esteja ligado a um tempo eterno, estrutural, que se repete com a passagem dos anos. É justamente porque reconhece o efêmero nos movimentos da vida, porque não ambiciona deixar um legado eterno à humanidade, que as obras onde o gesto se faz presente sobrevivem. Não faz sentido algum compor uma obra para a posteridade. O gesto encarna o transitório na sua mais justa medida. Ele carrega em si esse tempo sem nome que ao mesmo tempo aquilo que chamamos de passado, presente e futuro.

É “passado", na medida que depende da memória. Ao atuar/ dançar temas como a guerra, o amor, a morte ou o que quer que seja, o artista, mesmo que não tenha vivido situações semelhantes às da cena se utiliza de um repertório de experiências que de algum modo atravessa a história e a cultura dos envolvidos. Nada se apresenta pela primeira vez. Nenhum evento é completamente original. Sempre há uma variante do "já conhecido" no gesto, visto que ele lida com combinações de situações e linguagens comuns. Não é preciso ter passado por uma vida de miséria para reconhecer a pobreza e a fome. Se o gesto é marcado por uma diferença, uma interrupção que altera os rumos da experiência, essa diferença se configura a partir de elementos já visitados de um mundo possível. O espanto se sobressai naquilo que nos é familiar. $\mathrm{O}$ gesto habita o instante efêmero que faz a diferença no que de algum 
modo é conhecido intimamente. A surpresa despertada pela sua presença nos toca como a presença de alguém que não se via há algum tempo e que um belo dia chega sem avisar.

O evento provocado pelo gesto lida com o inesperado, a partir do encontro entre uma memória "voluntária" 26 , mais fácil de ser identificada (visto que lida com uma necessidade muito humana e quase irresistível de se fazer associações do tipo "isso me lembra isso") e uma memória "involuntária", que nos suspende no espaço e no tempo e nos arrasta para um outro lugar. Um lugar já visitado, já conhecido, mas visto sob um ângulo diferente. Daí o inesperado. Essa ida "forçada" nos retira momentaneamente do conforto de um lugar escolhido e domesticados. Mas ao invés de nos mostrar uma paisagem completamente nova, lança uma nova luz sobre uma paisagem já percorrida. É nesse sentido que o "esperado" provoca uma descontinuidade no fluxo dos eventos e o velho tensiona-se com o novo.

O gesto, que é marcado por um estranhamento, por um desvio, por um desacordo entre forças, só faz efeito quando circunscrito nos limites do que é provável, relacionando-se também ao que chamamos de "futuro", no sentido de um porvir. Aquilo que se encena nunca é o fato em si, mas uma provocação a infinitas possibilidades a serem vividas. O gesto evoca outros modos de vida, fala do que poderia ser, de uma multiplicidade de possibilidades talvez nunca antes imaginadas. Mas nada de outro mundo. "Cada gesto torna-se um destino" (AGAMBEN, 2008, p. 11). Um destino para o mundo. Ele nos obriga a olhar para a realidade de sempre, aquela com a qual nos confrontamos no cotidiano, mas sob uma outra perspectiva. Assim, o gesto ao mesmo tempo que é o passado que nos "espera" para ser revisto é uma aspiração futura.

\footnotetext{
"Tudo estava no lugar nos acontecimentos da minha vida antes que eu os fizesse meus; vivê-los é me ver tentado a me igualar a eles como se eles não devessem ter senão de mim o que eles tem de melhor e de perfeito". (BUSQUIET apud DELEUZE, 2011, p. 151)
}

O gesto é uma ferramenta para ir de encontro ao acontecimento, como se pudéssemos no efêmero nos tornar a causa daquilo que em nós se produz. Ele revê e prevê em sucessivos e infinitos presentes, criando em nós mesmos a nossa causa e consequência. Desse modo, ele busca, a todo custo combater a passividade ressentida.

\footnotetext{
${ }^{26}$ Noção de memória "voluntária e involuntária", inspirada no texto "Notas Sobre o Gesto" (AGAMBEN, 2008, p. 09-14)
} 
O ressentimento é a captação de um Acontecimento como algo injusto e não merecido. É um ressentimento contra o Acontecimento. Um sujeito ressentido é aquele que aceita uma punição, por não se crer merecedor de outro modo de vida. A sua dor é um castigo causado por uma condição anterior ("teve aquilo que mereceu"). Mas ao gesto não pertencem afirmações fixas do tipo "é assim porque era assim", nem "será assim, tem que ser assim, porque é e sempre foi assim".

O gesto marca um desejo que pode ser catalisador de um acontecimento. É o caminho para tornar-se aquilo que se quer ser. E o que significa querer um acontecimento? Será que é aceitar a guerra, a dor e a morte quando elas chegam? De alguma maneira, a resignação é também uma forma de ressentimento. A guerra não concerne a todo mundo; ela diz respeito àqueles que a servem ou se servem delas. A percepção de um acontecimento no sentido de uma guerra, por exemplo, possibilita a compreensão de todas as violências, em uma violência, todos os acontecimentos mortais em um Acontecimento. Ele denuncia e impede o ressentimento do indivíduo oprimido que não se resigna perante aos fatos.

Tendo como referência a observação crítica do mundo à nossa volta, o gesto cria possibilidades para o que se deseja viver. Nesse sentido, ele é sempre político. É da vontade que alguma outra coisa se opere que nascem as revoluções. O gesto habita o ponto em que a guerra é travada contra a guerra, em que a opressão é travada contra a opressão. A falta de vontade de morrer é substituída por um desejo que seja um explosão dessa vontade. Ou nos entregamos ao acontecimento e o encaramos de frente, ou somos engolidos por ele.

A música ${ }^{27}$ nos ajuda a pensar o tempo. A música formal ocidental, fundada em valores harmônicos, segue um “tempo pulsado". Esta música está mais ligada ao tempo cronológico, visto que nada, por mais impactante que seja, foge completamente à expectativa do compasso. Já a música do acontecimento é uma música flutuante, que lida com diferentes dinâmicas e velocidades, a partir de um "tempo não-pulsado". O gesto é uma experiência rítmica, ligada a uma breve interrupção no andamento das atividades. Diante do inesperado, que pode ser compreendido em diferentes escalas - como a dos grandes imprevistos ou a das micro percepções - somos surpreendidos por um instante de pausa, que logo em seguida torna a soar.

${ }^{27}$ BOULEZ apud DELEUZE, GUATARRI, 1997, p:42. 
“ 'Pôr em marcha esta paragem' consiste, portanto, em nos dispormos a suspender a reação padrão de (já) saber ou de voltar a saber e tomar este quê ainda sem nome sem passado para lhe dar causa, ou futuro para lhe dar meta - como meio". (EUGÊNIO, FIADEIRO, 2013, p.2)

Enquanto o acontecimento é o fogo, o gesto é a fagulha que o acende. Mas não uma fagulha anterior, e sim uma fagulha que permanece e sem a qual, nada queima. O gesto é atravessado por uma potência incendiária, por uma obstinação em querer viver outros modos de vida, até então inimagináveis, mas que só podem ser construídas a partir de materiais disponíveis ao redor. "Única forma, a meu ver, de nos mantermos no presente do nosso tempo e criarmos os anticorpos necessários contra a inércia, o preconceito e, no limite, a intolerância” (FIADEIRO, 2013, p: 4).

\section{6}

\section{Gesto e "Língua Menor"}

CENA 5. ESTÚDIO DE BALÉ. DIA. David, acompanhado de seu melhor amigo Eddie, assiste a uma aula de Balé pela janela. Lindas mulheres, altas, magras, de longas pernas, realizam uma sequência na barra. Inicialmente, vemos somente os pés das moças, descalços, em ponta, para frente, para o lado e para trás. Elas saltam. Lançam as pernas para o alto, equilibram-se e giram piruetas. David, sem titubear, abandona sua cadeira de rodas e invade a sala, porta à dentro, andando com os braços. Aos poucos, as bailarinas deixam a barra, se alongam no chão e partem. A aula vai chegando ao fim. No centro da sala, David se aproxima de uma delas, que ainda está sentada no chão. Para ao seu lado. Sem combinar, os dois erguem os braços, que se tocam, e juntos, iniciam um "pas de deux". O contato entre os corpos, impulsiona os dois para diferentes formas e encaixes. David se senta no colo da bailarina e o encontro das pernas dela, com o tronco dele, forma uma nova figura: um homem, uma mulher, e duas pernas longas e fortes. Um ser com dois troncos. Eles giram, dão cambalhotas. A figura se desfaz e dá lugar a novas figuras. Eles saltam um sobre o outro. Dançam, festejam, cada um com o seu corpo. Cada um com o corpo do outro. Com os corpos que não são de ninguém. ${ }^{28}$

${ }^{28}$ Cena livremente inspirada no filme "The Cost of Living", do DV8 Physical Theatre (2005). 
Como é difícil descrever uma dança somente com palavras. O que dizer desta, em especial? Como descrever o encontro, violento e delicado, entre corpos tão diferentes? Que metáforas usar para trazer para perto deste texto a sensação do fluir dos corpos, que parecem flutuar como se voassem pelo espaço da sala? Que provocação o corpo de David, pequeno, atarracado e sem pernas, faz ao corpo "perfeito" do balé clássico, ereto, forte e alongado? Que dança é essa, que faz referência ao balé, mas que não é balé? Que dança é essa, que solicita técnicas corporais diversas, que é virtuosa e demanda força, mas que a partir da técnica, provoca a técnica, dando a ver uma outra coisa?

David não aceita a imobilidade, não se acomoda no que pode se manifestar como obstáculo e também não se apresenta como a estrela de um show de “aberrações e variedades”. Ele sai de casa até o estúdio em direção ao seu desejo: dançar. A mulher que dança com ele, do mesmo modo, não o enxerga com superioridade ou pena. Os movimentos entre os dois se apresentam em uma relação de horizontalidade, de igual para igual. A dança não é conduzida por ninguém, pois a toda hora invertem-se os papéis de condutor e conduzido. A não-hierarquização de corpos tão diferentes desarticula muitos discursos de saúde, que relacionam aptidões do corpo à forma física. Não é o corpo reconhecido pelos padrões como o mais saudável que manda na relação entre os dois. Aliás, junto à diluição de papéis fixos como "condutor" e "conduzido", diluem-se também outras divisões, como "chefe" e "subalterno", "saudável" e "doente", "forte" e "fraco", "bonito" e "feio", "masculino" e "feminino", "ativo e passivo". Neste pas de deux, onde os corpos se perdem e se misturam, os dançantes se utilizam da língua-dança para mostrar que força, potência e presença ultrapassam o que se poderia acreditar como sendo limites da ação e da forma.

Podemos pensar nesta utilização do corpo como linguagem, sob a perspectiva daquilo que Deleuze chama de devir minoritário da língua (DELEUZE; GUATARRI, 2011, p. 11-63). Antes de mais nada é importante marcar que "maior" e "menor" não estão em oposição direta e nem são dois tipos de língua, mas dois tratamentos possíveis da linguagem.

Compreende-se "língua maior", como um conceito que diz respeito à língua dominante. Uma língua assertiva nos seus pressupostos, que nomeia o que é e o que não é; o que deve e o que não deve ser. Para se impôr como padrão e submeter os indivíduos às leis sociais, a "língua maior" parte de uma unidade. "A unidade de uma 
língua é, antes de tudo, política”. (DELEUZE, 2011, p. 49) Não se trata da línguamaterna ou de um idioma, mas de um modo discursivo de se afirmar como poder instituído. Uma linguagem que a todo custo tenta banir os desvios, temerosa de que as variações sobre si inspirem também variações de modos de existir que ameacem o seu controle.

A "língua menor" vai além da multiplicidade de dialetos. Não é uma outra língua, uma língua local ou uma língua de minoria. O "minoritário" é antes de mais nada, um devir potencial que se desvia de discursos centralizados e homogeneizados. Não se trata exatamente de uma mistura linguística, mas de um modo de desterritorializar a língua dominante. O devir minoritário-revolucionário recria a língua, trazendo à tona todas as suas possibilidades de minoração, de desconstrução e de reavaliação. É a invenção caótica e renovada de uma língua na própria língua, não chegando nunca a formar uma nova língua. É a utilização da língua que ressalta não aquilo que ela é, mas aquilo em que ela se transforma. Ao invés de ser uma simples oposição ou alternativa à "língua maior" é algo que só se cria a partir dela.

"A minor language is a major language in the process of becoming minor, and a minority a majority in the process of change" (Parr, 2010, p. 167-168) ${ }^{29}$.

A Dança Contemporânea, como devir de uma linguagem questionadora e em desequilíbrio, aposta na "língua menor", pelo fato de se relacionar mais com uma ideia de método, do que com uma técnica. Em outras palavras, ela não parte de um modelo único, como o balé clássico, por exemplo, que busca, sobretudo, a execução técnica perfeita de movimentos e dinâmicas, construídos a partir de um repertório de posições e posturas finitas. O balé como uma instituição, reforça certos valores, mais do que contesta ${ }^{30}$. Na dança contemporânea, cada projeto, cada criador e cada criação busca o seu próprio caminho. O projeto estético é uma reação e uma indagação ao mundo que o cerca. Foi concebido nesse mundo e é com ele que dialoga, dando voz ou abalando algum discurso. A cada obra, o artista precisa eleger seus procedimentos, mas nada em absoluto. As ferramentas que serviram para um trabalho podem aparecer de maneira completamente diferente em outro. Nesse sentido, há uma

\footnotetext{
${ }^{29}$ Minha tradução: “A língua menor é a língua maior em processo de tornar-se menor, e uma minoria, uma maioria, em processo de mudança".

${ }^{30}$ Importante ressaltar que, nos últimos anos, o próprio pensamento sobre o método do balé tem sido revisto por muitos educadores, levando em conta e respeitando as possibilidades de cada corpo.
} 
impossibilidade da dança contemporânea de ser apreendida, estruturada ou repertoriada como um conjunto fechado de técnicas. O que não significa que não haja técnica e que o dançarino contemporâneo dance apenas intuitivamente, sem nenhum conhecimento sobre o seu corpo. Contudo, a técnica não se direciona a um único destino. O dançarino deve buscar ampliar seu repertório e aprofundar suas possibilidades, pois o que está em jogo é o despertar constante de questionamentos, a partir das escolhas técnicas/ estéticas.

Aliás, o próprio balé pode ser utilizado como ferramenta e referência pela dança contemporânea, mas isso não quer dizer que o artista "rapte" o sistema do Balé de um "reino" já consolidado e aceito como padrão para conduzí-lo a outro "reino" menos "nobre". O dançarino ou o coreógrafo que aspira o gesto cria um novo espaço, a partir da junção de reinos diferentes, de técnicas diversas. E nesse lugar que não é lá nem cá, territorializado e desterritorializado a partir de uma nova cartografia, o público se vê diante da possibilidade de criação de novos reinos, sem reis, nem senhores, de novos povos, de novos modos de existir.

Do encontro de zonas tão distintas e diferenciadas emerge uma zona de aproximação, indeterminação e indiscernibilidade. David e a bailarina de alguma forma fazem alusão à tradição, à sistematização e aos códigos do Balé, ao mesmo tempo que inserem elementos técnicos mais contemporâneos como o "contatoimprovisação" e técnicas da bagagem cada um. Mais do que um novo vocabulário, os bailarinos criam uma nova sintaxe, a partir da combinação desses muitos elementos. A língua de muitos reinos perde seus territórios de origem. Constitui-se como um território estrangeiro dentro da própria língua, em um ponto em que a técnica serve para fazer "gaguejar" o próprio discurso da técnica. ."A beleza do seu estilo é obter a gagueira pela instauração de linhas melódicas que arrastam a linguagem para fora de um sistema de oposições dominantes”. (DELEUZE, GILLES, 2010, p. 49) A referência, qualquer que seja, serve como um instrumento de desarticulação. Uma gagueira que se dá justamente onde alguma coisa não consegue ser dita, expressada, nessa tentativa de tentar dizer o que não se consegue. Os bailarinos se utilizam das línguas à sua volta, inscritas nos seus corpos, para criar uma língua estrangeira, que parece ser muito própria, na medida em que é uma marca. Essa marca, o traço, a cicatriz, que até podemos chamar de estilo é constituída por um conjunto de relações criadas para além da habilidade. E isto é também o que há de mais impessoal, visto que possui uma potência forte demais para pertencer a uma pessoa só. 
O pas de deux "encenado" neste capítulo é inspirado em uma cena do filme da Companhia DV8, que parece desmembrar técnicas sistematizadas, como o balé, o contato-improvisação, a dança moderna, a dança de salão, danças de rua, entre outras tantas modalidades às quais faz referência, ainda que indiretamente, não chegando a assumir nunca uma única técnica ou linguagem. Essa perda de unidade e hegemonia na dança, que se manifesta diretamente em relação aos corpos envolvidos é o que nos interessa aqui.

A partir de discursos com o corpo, criar outros modos de discurso, outras possibilidades de viver corporalmente. $\mathrm{O}$ corpo do dançante não aceita passivo as imposições sociais vigentes. Ele se encontra sempre na periferia, à margem, mas não necessariamente por uma via econômica, social ou cultural. É um corpo desviante. "Nenhum gesto é inocente, nenhuma dança é só estética". (LIMA, 2013, p. 11).

Se nos dizem para sermos "assim", nós vamos lá e investigamos outras possibilidades da existência, indo em busca, inclusive daquilo que nos dizem que é impossível. (Aliás, quem diz? Quem emite os discursos, e tem o controle da sua proliferação? Não seremos nós?) Se nos dizem que não somos capazes, mudamos os critérios de capacidade, buscamos outras posturas, outros comportamentos, outras maneiras de lidar com o espaço, com o tempo, com o movimento. Passamos por estados que eles chamam de selvagem e monstruoso porque essas são possibilidades do homem. É preciso desconfiar do que se chama de humano.

Se o gesto pudesse falar, o faria em "língua menor", entre a significação e o não-senso, desafiando justamente essa necessidade de associação simbólica que aparece tão entranhada em nós. A dança convoca o símbolo, que ela própria esvazia. Ao mesmo tempo que significa, visto que somos sujeitos criados na linguagem, não esgota todas as possibilidades de significação e significado, já que não se encerra um único sentido. Ideias e posturas hermenêuticas, que têm como objetivo a interpretação de uma mensagem, uma comunicação que se endereça à compreensão e atividades intelectuais que tentam dar um sentido unívoco à linguagem são remexidas pela experimentação da ordem do acontecimento. "O gesto é, neste sentido, a comunicação de uma comunicabilidade" (AGAMBEN, 2008, p. 13). Ele não tem nada a dizer, porque não é um instrumento de utilidade cujo o encaminhamento se direciona a conclusão final de uma mensagem, mas um dispositivo que vai abrindo espaços. Ao invés de buscar um fim do trajeto, o gesto encontra-se no desconhecido do caminho. Diante de infinitas bifurcações, ele não sabe para onde ir, nem faz mais 
ideia de como voltar. Esse não-saber é uma espécie de nascimento da língua. Não um nascimento que possa ser compreendido em um sentido cronológico sequencial (nascer, crescer e morrer, no fim de tudo), mas um nascimento frequente no meio dos acontecimentos. Uma morte entre o nascimento e o crescimento. Um crescimento entre a morte e o re-nascimento. Renascer no sentido de resgate à capacidade de espantar-se com o mundo. A experimentação do recém-nascido ainda não conhece as estruturas, desse modo ela provoca a estrutura, põe em dúvida sua constituição.

O foco não está na apreensão do significado ou nas condições que permitiram a configuração de um determinado sentido, mas sim nas possibilidades de modificação e interrupção do sentido, a partir das próprias ferramentas do sentido, visto que sentido e presença, ao mesmo tempo em que se enfrentam são mutuamente constitutivos.

Pelo fato de não querer tornar-se dominante, a "língua menor" não tem função representativa, opta pelo informe, pelo multiforme, está sempre se recriando, se questionando. É inesgotável. No aprendizado e na experimentação contínua que concerne ao gesto, reside a tentativa incessante de dizer o impossível. Tentar de todas as formas dizer o indizível. Dançar com a linguagem, ali onde a linguagem não é suficiente.

"Uma linguagem levada ao extremo limite, elevada à potência do indizível, torna possíveis visões e audições libertas do empírico, visões e audições superiores, puras, capazes de ver o invisível, de ouvir o inaudível”. (MACHADO, 2010, p. 212)

Enquanto a "língua maior" tenta se afirmar pelo discurso assertivo do sentido e da significação, a "língua menor", do gesto, lida com o lugar vibrátil, intensivo da língua-dança e da língua-corpo. É a presença que usa a carne como veículo. Podemos tentar descrever essa presença, mas ela é justo o indescritível e o indizível da linguagem. Muito mais do que rejeitar completamente a linguagem e a significação, a "língua menor" duvida o tempo inteiro da linguagem e sobretudo, de si. Essa qualidade questionadora, que a faz inapreensível em um só nome, em uma só forma, em um só significado, lugar ou gênero, é a sua maior arma; pois não há afronta maior para quem estabelece classificações do que aquilo que é inclassificável. "Um corpo que desenvolve uma atmosfera afetiva, como se exalasse e liberasse forças inconscientes que circulam a flor da pele"31. Não se trata de trocar uma linguagem por outra. A força do gesto não está no embate de um projeto contra o outro. Como a

31 PALBERT, Peter Pal. 
nova roupa do rei, a língua menor toca o corpo-linguagem, mas não o cobre, pelo contrário, desnuda o corpo, expõe sua permitividade, a sua animalidade, sua humanidade. Mostra ao reino as coisas primeiras, que pareciam esquecidas e inconcebíveis.

"Se não quero das palavras seu sentido, mas aquilo que carregam realmente, e do incêndio quero o fogo e não a rima, da sombra, o escuro e não a posição gramatical, se do amor não quero nada por querer dizer coisas demais, então devo me chamar como o náufrago Ninguém, sem querer de ninguém o seu sentido, mas aquilo que vem antes, ainda sem ter estado lá; se da terra quero o que brota e afunda, mas antes que houvesse tempo, e habilidade, para chamar aos frutos a aos mortos, mortos, então seria melhor apagá-las todas, às palavras, uma a uma, às negras pequenas aranhas, livrando o dicionário dessa mácula, e beber o que foi tinta até a boca ficar preta e transformar a tinta em chuva, em tigre". (RAMOS, 2010, p. 55) 


\section{4}

\section{Uma Dramaturgia de Gestos}

O que seria uma dramaturgia de gestos? Uma dramaturgia composta por uma sequência de gestos? Uma dramaturgia produtora de um gesto catalisador de outros gestos? Como é possível produzir uma dramaturgia desta ordem? Quais os procedimentos utilizados para alcançá-la? O gesto deve ser encarado como ponto de partida ou consequência desse tipo de escrita? Como ser tocado por um projeto artístico sob essa perspectiva? Como identificar a presença do gesto na dramaturgia, se o próprio conceito diz respeito a uma presença que não se fixa a uma forma única? Quais características de uma dramaturgia falicitariam a identificação do gesto? Por que não olhar a dramaturgia pela perspectiva do movimento, da arquitetura, do texto ou das ações?

A busca pela inflexão de um conceito de "dramaturgia de gestos" se dá, sobretudo, a partir de um desejo. Não se trata de eleger um elemento material da dramaturgia para destrinchar junto ao leitor suas relações e seus efeitos de escrita. $\mathrm{O}$ desejo aqui diz respeito a um direcionamento do caminho por onde passam os elementos constituintes de uma escrita dramatúrgica. Escolher um modo de olhar: a opção por esta abordagem se interessa mais pelo "como se olha" do que pela análise de um objeto à que se faz referência. O gesto não é um signo ou um elemento material fixo. Ele aparece na relação entre esses elementos. Não há receita ou método para alcançá-lo. Até porque ele não carrega sempre as mesmas características.

O conceito de "dramaturgia" pode ser compreendido pelo menos de duas maneiras. Na primeira delas, quando encarada como Literatura, se apresenta no formato de um texto composto por palavras (falas ou rubricas), como sugestão de montagem cênica. Ela pode ser lida apenas "no papel”, não dependendo da execução propriamente dita para ser concretizada. Nesse sentido, ela supõe que o leitor imagine a encenação. Apesar desta não ser a abordagem principal da nossa crítica é importante reconhecer a potência que a dramaturgia como texto literário à priori pode ter. Ainda hoje, uma multiplicidade de textos vêm sendo criados e discutidos justamente pela perspectiva dos gestos de pensamento que o atravessam.

Entretanto, para além do texto, podemos pensar no discurso dramatúrgico como uma escrita cênica constituída por pontos de cruzamento entre materiais tais 
quais: performers, objetos, cenários, paisagens, textos, sonoridades, estados, ritmos, vibrações, intensidades, cores, entonações, densidades, volumes, etc. Esses materiais, ao interagirem dinamicamente com a espacialidade, os ritmos e a duração, estabelecem relações de sentido no tecido da encenação. Sentido esse, que nunca é fechado e nem aponta para uma única direção; pelo contrário, traz à tona infinitas possibilidades de sensações e de significações. Essa segunda abordagem nos interessa mais, considerando que desejamos investigar o gesto não apenas a partir do texto escrito, mas no tecido do próprio acontecimento performativo. Não se trata de uma oposição ou de uma negação à dramaturgia vinculada ao texto, mas de uma percepção que buscar ultrapassar qualquer relação de subordinação do teatro à Literatura.

E por que partir da dramaturgia e não optar por um outro modo de escrita? Embora o termo "dramaturgia" esteja vulnerável à influência de diferentes experimentos artísticos é inegável que sua relação mais próxima se estabeleça com as Artes Cênicas (Teatro, Cinema, Dança, Peformance e todas as suas variações). A dramaturgia é um modo de discurso que utiliza a cena como principal canal de realização. Trata-se de um escrita que pode se materializada corporalmente na frente de um público.

O espectador é condição necessária para a realização da experiência performativa, modificando diretamente não só a leitura do objeto, como a própria construção da obra. O público é também responsável pelo traçado da obra. Cada público, uma peça. As assinaturas dos artistas e da plateia se perdem e se misturam. Os elementos, as respirações, os batimentos cardíacos, se devoram uns aos outros, servem de alimento para novos materiais e novos espaços.

Se a dança, sobretudo a dança contemporânea como manifestação artística, nos interessa por reivindicar outras possibilidades para o corpo, possibilidades para além das posturas padrão, a escolha pela dramaturgia se dá pelo interesse por um determinado tipo de relação entre esses "possíveis" corpos. É pela vontade de ver uma escrita que se escreve e se inscreve nos corpos da cena, que ela aparece como material de investigação.

A escolha pelo conceito de dramaturgia, considerando sua relação primária com o teatro, talvez também se dê por um modo de se vivenciar a passagem do tempo. Teatro significa: atravessar um tempo de vida em comum. Artistas e espectadores respiram juntos o espaço e a duração. A maior especificidade das artes performativas é seu caráter efêmero. Os efeitos de uma experiência ficam guardados 
na memória dos participantes, mas diferente de um livro, de um filme ou de uma canção, a escrita de uma peça não pode ser "guardada" na forma de um livro, de um vídeo ou de um disco. Nas artes performativas, as escolhas de materiais e os vínculos estabelecidos podem ser das mais diversas ordens, entretanto, eles só existem enquanto dramaturgia no tempo real da apresentação do espetáculo. É a partir do encontro promovido pela obra que o discurso enunciado no palco é atualizado. Mesmo que haja a interferência de um vídeo, de uma voz gravada ou da internet é sobre o tensionamento do "ao vivo" que eles se colocam. A escrita cênica lida com o transitório na medida em que as relações entre os elementos dependem daquele período de execução do espetáculo. Quando o conceito de dramaturgia encontra-se expandido por outras áreas e suportes artísticos, o que interessa é essa relação com a transitoriedade. Pensando desta maneira, podemos nos perguntar o seguinte: como escrever um livro ou compor uma canção com a urgência de um tempo efêmero que não pode ser apreendido?

Se hoje em dia já encaramos o texto como mais um material de composição da cena, ainda é importante reconhecer que o conceito de dramaturgia esteve muito tempo atrelado à Literatura. Não faremos aqui uma genealogia do teatro, nem tentaremos dar conta de uma justificativa pela filiação de estéticas e movimentos. Se evocamos alguns conflitos que inevitavelmente respondem às questões do seu tempo, nosso esforço é para que não pareça que estamos tentando dar conta de uma evolução sequencial de fatos e acontecimentos. Não obstante é preciso ter consciência que certos conflitos não se colocam assim, sem mais nem menos e estão sempre em relação com outros desejos e conflitos. Trazemos aqui uma breve descrição de como a relação entre teatro, drama e Literatura se colocam em abalo, mais para pensar nas discussões sobre o que se opera entre o "sentido" e a "presença", do que para situar o leitor em uma linha do tempo.

Assim, podemos dizer que o teatro europeu, entre o século XVIII e a primeira metade do século XX, voltado para a elite burguesa, compreendia a dramaturgia como a produção de textos dramáticos compostos pela figura de um escritor. $\mathrm{O}$ texto apresentava uma função hierárquica superior aos outros elementos da cena. Importante ressaltar que figuras importantíssimas na trajetória da História do Teatro, como Antoine e Stanislávski, vislumbraram um teatro para além do texto e dedicaram-se, cada um a sua maneira, à investigação desta outra linguagem teatral, ligada aos diversos signos de encenação e atuação. Ambos reconheciam o potencial 
expressivo daquilo que era próprio da cena e que não necessariamente estava explícito no texto; aquilo que tornava o teatro diferente de uma simples leitura. Inseridos em um contexto de transformação e mutação da cena (e não estaremos sempre em contexto de transformação?), os dois pensadores deram destaque à figura do diretor e do encenador no desenvolvimento das montagens teatrais. Contudo, nesse contexto, todas as escolhas da encenação deveriam se dar em função de uma coerência narrativa proposta pelo drama. Os atores assumiam o discurso do encenador, que por sua vez seguia o autor que tinha em mãos. A cena se colocava à serviço do texto, mesmo quando se reconhecia contradições e ambiguidades dos personagens e da trama. O teatro "dramático", que de algum modo pretendia construir na cena um cosmos fictício ilusionista no qual o palco aparecia como representação do mundo, almejava uma totalidade cognitiva e narrativa, a partir de uma coesão entre as unidades de espaço, tempo e a construção dos personagens. Desse modo, todos os elementos de uma montagem teatral, inclusive a movimentação física dos atores deveriam estar submetidos à comunicação e à coerência narrativa do texto.

Mas se o teatro padrão era o teatro do texto e do "drama", havia também aqueles que se confrontavam com aquilo que se colocava como modelo. Alguns artistas e pensadores já reivindicavam o fim da supremacia do texto nas práticas teatrais, do drama psicológico e até mesmo o lugar do diretor como intermediário entre o autor e os atores. A primeira metade do século XX foi também marcada por um debate entre territórios de autoria, abalando a relação entre a dramaturgia e encenação. Além disso, a cena moderna lança olhares para outros meios de expressão, apropriando-se de seus materiais e pondo em questão a Literatura como elemento central.

Artaud, por exemplo, critica o teatro burguês tradicional no qual o ator é apenas um agente do diretor, que por sua vez "repete" aquilo que foi dito pelo autor, em uma tentativa de representação do mundo. Seu desejo se direciona a um teatro que não seja uma reduplicação. Ao invés de um lugar de cópia, o teatro deve ser origem e ponto-de-partida de um mundo. Desta forma, Artaud chama a atenção para o Teatro de Bali, muito mais voltado para a dança, o canto, a pantomima e a música, do que para o teatro psicológico, propulsionado pelo elemento literário, vivenciado na Europa de sua época.

No Teatro de Bali, as situações funcionam como um mero pretexto, no qual a evolução dos acontecimentos não se desenvolvem através dos sentimentos 
psicologizados, mas daquilo que Artaud chama de estados de alma (ARTAUD, 1999, p. 71), materializados em gestos. O diretor, influenciado por este teatro, segundo Artaud, cria a partir dos estímulos da própria cena e não tentando dar conta de um texto escrito previamente. A trama não é o fundamental. O que faz pulsar a vida é o desenvolvimento dos artifícios cênicos através de um jogo de relações entre gesto, voz e espaço. Mais importante que a definição daquilo que se coloca em cena é a maneira como isso é colocado.

\footnotetext{
"Nosso teatro que nunca teve ideia dessa metafísica de gestos, que nunca soube fazer a música servir a fins dramáticos tão imediatos, tão concretos, nosso teatro puramente verbal e que ignora tudo o que constitui o teatro, ou seja, tudo o que está no ar do palco, que se mede com e se cerca de ar, que tem uma densidade no espaço movimentos, formas, cores, vibrações, atitudes - poderia, diante do que não se mede e que se relaciona com o poder de sugestão do espírito, pedir ao Teatro de Bali um lição de espiritualidade." (ARTAUD, 1999, p. 59)
}

O que Artaud parece buscar no Teatro de Bali, não é a exclusão total da palavra. E a questão também não é apenas trocar a palavra pelo movimento e a mímica. Mais do que isso, Artaud reivindica um gesto que atinja o espectador intuitivamente, com tamanha violência, a ponto de tornar inútil toda a tradução reduzida a uma linguagem lógica e discursiva.

“(...) uma espécie de linguagem teatral exterior a toda linguagem falada e na qual parece residir uma imensa experiência cênica ao lado da qual nossas realizações, exclusivamente dialogadas, parecem balbucios". (ARTAUD, 1999, p. 60)

A direção apontada não somente por Artaud, mas também por Gordon Craig, Maeterlink, Meyerhold, entre outros artistas percussores de uma nova teatralidade, para além do drama e da construção de um personagem a partir da mimeses, demora quase meio século para realmente se fazer notar. Nos anos 60, nas práticas de Jerzy Grotowski, as palavras aparecem como material plástico de exercício criativo do ator e não apenas como portadoras de sentido de uma narrativa. O texto, quando existe, é mais uma ferramenta e não o território base de composição da cena. $\mathrm{O}$ ator, criador de movimentos e ações, lida com o próprio corpo, compõe a sua gramática, não estando mais à serviço da realidade do texto ou do desenho da cena, pensado e "marcado" pelo diretor.

Ao longo dos anos, a autoria, ao se expandir para fora do domínio do escritor, ganha um novo componente, o diretor ou o encenador, e também começa a 
reconhecer o ator ou o bailarino não mais como simples intérprete, mas como coautor, responsável por uma obra. Nos anos 70, nasce a expressão "escrita cênica", que reconhece o espetáculo como obra autônoma e compreende a encenação como a organização e a interação de um conjunto de sistemas cênicos, dentre os quais o texto é apenas mais um elemento. A cena não é um um produto derivado do texto, mas o próprio fundamento do fazer teatral. Além disso, uma nova tarefa para os artistas formados segundo o modelo europeu é aprender a lidar com o corpo a partir de outras experiências, de outras referências, presentes no mundo todo.

Os territórios do Teatro, da Dança, da Performance, do Vídeo, das Artes Plásticas, da Literatura e da Música, cada vez mais se desterritorializam e tomam de empréstimo novos territórios. $\mathrm{O}$ teatro, influenciado pelas performances e happenings, investiga o improviso e os processos de criação coletiva. Pouco a pouco a responsabilidade criativa de um espetáculo vai escapando do domínio individual e os grupos e companhias ganham destaque na cena do mundo todo. Diluem-se as hierarquias ou pelo menos elas se reconfiguram de acordo com o interesse de cada grupo ou de cada projeto, sem chegar a se estabelecer como único modelo. Atualmente, já falamos em "escrita colaborativa", na qual todos os participantes envolvidos são corresponsáveis pela criação de um trabalho. As encenações têm à sua disposição infinitas possibilidades de relação espacial e de duração. São incontáveis as possibilidades de disposição do público: espacialmente, quantitativamente e no que diz respeito à própria relação com a participação. O público pode ser colocado em cena, assim como é possível utilizar não-atores ou não-bailarinos em uma montagem profissional. Cada grupo e cada artista vem munido do seu próprio repertório de técnicas e vivências, sendo difícil seguir um único modelo, mestre, pedagogia ou uma única escola de criação. Um processo criativo pode durar algumas horas ou alguns anos. A convivência entre tantas formas e procedimentos de expressão dificultam a apreensão das Artes Cênicas em uma categoria estável e definível.

Hans-Thies Lehman, utiliza o conceito de "Pós-Dramático" para analisar inúmeros processos cênicos multifacetados presentes a partir dos anos 70. Não se trata, para Lehman, de uma referência à supressão completa do texto dramatúrgico. No decorrer da sua análise, o autor inclusive aponta para uma variedade de textos autênticos que surgiram ao longo das últimas décadas e diz que, se por um lado, a pressão exercida nos dias de hoje pela velocidade e a superficialidade das 
informações, pelo acúmulo e excesso de imagens, exigem que a cena se destaque da literalidade no que concerne a dependência do texto dramático, por outro, tanto a Literatura quanto o palco, demandam uma liberação de energias e fantasias ativas, que se opõe ao corrente consumo passivo de imagens e informações (LEHMAN, 1999, p. 17).

O teatro Pós-dramático é considerado pelo teórico um teatro pós-brechtiano, pois situa-se em um espaço aberto por questões propostas por Brecht sobre a presença e a consciência do processo de encenação a partir de uma nova "arte de assistir", que convoca a participação e o engajamento ativo do público. Contudo, ele se difere do projeto de Brecht, no que diz respeito ao estilo político e dogmático, com ênfase na experiência racional.

Lehman faz um inventário de diversos aspectos relevantes a este teatro como: ambiguidade, simultaneidade, celebração da arte como ficção, valorização e apresentação do processo criativo, percepção do teatro como jogo, heterogeneidade, descontinuidade, desconstrução, ausência de texto, diversidade de códigos, pluralidade midiática, performance como elemento pulsante entre o drama e o teatro, caráter antimimético, rejeição da interpretação, entre muitos outros. $\mathrm{O}$ autor ainda identifica elementos herdados do teatro dramático como fragmentação narrativa, componentes hipernaturalistas, grotescos e neo-expressionistas.

Se por um lado, Lehman marca em sua abordagem um distanciamento do drama, por outro, o "pós" utilizado em sua nomenclatura significa que algo do "dramático" continua a existir como estrutura. Reconhece-se no teatro Pós-dramático elementos do organismo dramático, que apesar de servirem como um "material morto, ainda estão presentes e constituem o espaço de uma lembrança em "irrupção"” (LEHMAN, 2007, p. 34). Mas até quando a arte precisará se direcionar cronologicamente a uma estética anterior para se afirmar a partir de uma negação? Será que atualmente, com tantas possibilidades estéticas e plásticas, inclusive relacionadas a trabalhos artísticos que não têm a Literatura como referência, estaremos de alguma forma ainda nos relacionando com o drama? Se a intriga deixa de ser ingrediente do teatro para dar lugar a uma sucessão de composições entre corpos, ritmos e espacialidades, até quando será preciso à dramaturgia evocar o dramático, de modo quase paradigmático, como lembrança e negação para abordar obras que talvez já não queiram mais abalar o que se compreende como sendo o modelo dramático? 
Percebe-se no termo "Pós-dramático", a relação de aproximação e distanciamento, aniquilamento e paixão com o sentido, com a linguagem, com a unidade, com a compreensão, com a linearidade e com a interpretação. O gesto só desarticula esses aspectos porque de alguma maneira ainda se remete a eles, mesmo que por uma lembrança. Ele rompe com a lógica do teatro psicológico. E só é possível romper com aquilo que de um jeito ou de outro se faz presente. Isso não quer dizer que recursos narrativos ou que outros elementos do teatro do "drama" impossibilitem a manifestação do gesto. Aliás, muitas vezes eles se colocam justamente como ferramentas para a sua criação. Da mesma forma, nada garante que um trabalho com pouquíssima incidência e relação de elementos dramáticos (por exemplo: técnicas de "teatro físico" ou diversos tipos de apelo à plasticidade) provoque os abalos à cronologia, à totalidade ou ao sentido, referentes ao gesto.

Escolhemos, desde o capítulo anterior, a dança como linguagem, para falar do desejo por uma certa abordagem do corpo na dramaturgia, apesar de não sabermos mais ao certo como localizar a diferença entre a dramaturgia da dança e a do teatro; visto que não são categorias estáveis e que cada projeto solicita seu próprio procedimento de escrita. Talvez a dança, bem como as artes plásticas e a performance esteja menos ligada a uma ideia de coerência ficcional clássica por ter um vínculo menos direto com a Literatura escrita. Talvez o encadeamento das posturas em dança seja mais rítmico do que causal, visto que o teatro falado ocidental sempre foi, muito mais que a dança, o herdeiro da produção de sentido dramático. Como estamos vendo, a dramaturgia já não pertence ao campo exclusivo do teatro e o próprio teatro não se constitui como um campo exclusivamente localizável. Os projetos artísticos que nos inspiram para essa pesquisa - como por exemplo, aqueles que foram apresentados em forma de cenas no capítulo anterior - provocam justamente um corpo que o tempo inteiro pendula entre a significação e a não-significação, entre o conhecido e o desconhecido. Convocamos o conceito de Pós-dramático para pensar, não pela perspectiva de oposição de gêneros, mas por aquilo que, no enfrentamento ao modelo dramático, evoca um corpo que tenta romper com a sua significação e não obtendo um êxito completo, pendula entre o sentido e a sua ausência. Evocamos o dramático, não por acharmos que este seja um "modelo" ultrapassado, sempre a ser negado, ou por crer que a tradição do teatro tenha que se definir como abordagem soberana para a dramaturgia. Evocamos o dramático e o seu "pós", pelo fato do drama muitas vezes ser associado a modos de 
discurso que o gesto tenta enfrentar, ainda que não consiga escapar completamente deles. As orientações piscologizantes e interpretativas que o gesto abala estão muito introjetadas nos nossos corpos, na nossa vida cotidiana e na maneira que ainda se pode lidar com as Artes Cênicas. Pois mesmo hoje é comum alguém (claro que há muitas exceções, mas pessoalmente eu ainda escuto) antes de ir ao teatro perguntar: “sobre o que é esta peça?" ou então "qual é a história?", como se a experiência artística pudesse ser apreendida por uma fábula ou uma macro-narrativa. Existem espectadores que não suportam assistir trabalhos de dança porque não "o compreendem" e por esta razão, os consideram maçantes. Esse outro tipo de relação com o saber, um saber mais sensível do que hermenêutico, um saber mais da experiência do que da compreensão, incomoda muito. Do mesmo modo, o apego ao sentido se manifesta na postura de alguns canais da mídia e da crítica (não de todos, ainda bem). Há, em muitas casos, uma pretensão do crítico em ser aquele que detém a verdade e o poder de atribuição de qualidade à obra. Trata-se de um tipo de crítica que insiste em conferir se determinados signos são "apropriados" para compor uma narrativa ou uma significação. $\quad$ Para além do sentido, Lehman aponta para uma relação do corpo pós-dramático com a sua presença. Trata-se de um corpo da força e da experiência. Ele não se apresenta por sua capacidade de significação, apesar de em algum lugar convocá-la. Segundo o autor, o corpo Pós-dramático é um corpo do gesto, sendo o gesto, aquilo que no meio de uma ação, rompe com a lógica de ordenação, provocando uma suspensão “ofuscante” (LEHMAN, 2007, p. 342), cuja potência transborda à finalidade do que estava sendo feito. Em referência à finalidade, o gesto rompe com a sua própria lógica, não tendo finalidade nenhuma. Sua presença provoca uma perturbação de tal natureza que acarreta em uma pausa no sentido (LEHMAN, 2007, p. 342). A experiência deste teatro, sobre o qual Lehman se debruça e que nos interessa, nunca chega à uma conclusão uniformizante, pelo contrário, investe em uma percepção aberta, fragmentada e em processo.

"O gesto é aquilo que fica em suspenso em cada ação voltada para um objetivo: um excedente de potencialidade, a fenomenalidade de uma visibilidade como que ofuscante, que ultrapassa o olhar ordenador - o que se torna possível porque nenhuma finalidade e nenhuma reprodutibilidade enfraquece o real do espaço, do tempo e do corpo" (LEHMAN, 2007, p. 342).

Evocamos a leitura de Lehman, reconhecendo sua suma importância para a teoria da cena nas últimas décadas do século $\mathrm{XX}$ e ainda hoje. Certamente que 
estamos atentos às críticas feitas à sua proposta de abordagem por diversos teóricos. Contudo, o que nos interessa, tanto em Lehman, quanto na noção de performatividade, que será vista brevemente a seguir, não é uma contraposição de pontos-de-vista e enfoques ou a escolha de único modo de encarar a cena contemporânea - cena esta que há algum tempo atravessa uma crise epistemológica mas justo o contrário, o tensionamento de vocabulários e abordagens que atravessam os projetos artísticos dos últimos anos. Josette Féral, Rose lee Goldberg, Erika Fischer-Lichte, entre outros autores, fomentam as discussões sobre as Artes Cênicas do ponto de vista da performatividade. Não será possível dar conta de toda a extensão de estudos e formulações acerca desta noção. Ainda assim, iniciamos pelo que Sílvia Fernandes (2013, p. 408) marca como o caráter processual da performance. A autora faz referência à Fischer-Lichte, compreendendo a performatividade como extensão natural do campo do teatro, mas não como um novo paradigma que se opõe ao teatro. Para Fischer-Lichte (FÉRAL, 2011, p. 11-23 e 2013, p. 404-419), a experimentação é mais importante que a interpretação. A atividade cênica ou performativa é encarada como uma travessia que convoca os envolvidos à participação, mais do que à contemplação passiva ou a decodificação de signos, o evento lida com uma atmosfera compartilhada e comum, capaz de proporcionar uma experiência para além do simbólico.

Féral (FÉRAL, 2011, p. 11-23 e 2013, p. 404-419), assim como FischerLichte, reconhece a influência da performatividade na mudança de enfoque da cena, que sai da representação em direção ao próprio acontecimento. Por essa razão, Féral lida com a esfera do teatro performativo. Enquanto o teatro é visto como o lugar de um determinado tipo de inscrição simbólica, a perfomance objetiva justamente romper com esse tipo de relação. Para Féral, a teatralidade constitui-se de um jogo de embate entre essas qualidades, entre as estruturas simbólicas específicas do teatro e os fluxos de energias que se atualizam sempre a partir de uma performatividade inconclusa. Há um tensionamento entre aquilo que define a obra e o seu acontecimento para além da obra, que se aproxima bastante da "esfera do real" (FERNANDES, 2013, p. 404-419) e da presença do encontro propriamente dita. Podemos apontar nesta noção, o desejo de colapso aos antagonismos binários como sujeito/objeto, significante/ significado, e principalmente, realidade/ficção.

Se compreendemos o gesto como uma presença dilatada para além da cronologia e da individualidade, uma presença que promove um abalo na linguagem e 
uma cisão nos seus participantes durante determinado evento; devemos perceber que este se constrói e se desperta na dramaturgia, a partir de alguma coisa que transborda os componentes materiais da escrita. O gesto se articula com "um aspecto revelador da matéria que parece de repente se disseminar em signos para ensinar a identidade metafísica do concreto e do abstrato" (ARTAUD, 1999, p. 63).

O gesto se faz concreto com o auxílio daquilo que é palpável, tangível, visível ou audível. Ao mesmo tempo, o gesto evoca o abstrato, pois "quando encontra em voo, impressões do mundo da natureza, agarra-as sempre no ponto em que dão início a seu agrupamento molecular; isto significa que apenas um gesto ainda nos separa do caos". (ARTAUD, 1999, p. 69). Destas palavras de Artaud, podemos pensar que o gesto na arte habita o instante-limite entre uma força criadora e a matéria. Entre o caos e o tangível, entre a desordem e a organização.

A relação entre forma e força é uma questão enfrentada pela poética do gesto. Como, por baixo da forma, deixar transparecer a catástrofe que a tornou possível e as forças que constantemente a transformam? A dramaturgia é responsável por relacionar os materiais da cena, dando sustentação para que o caos não domine a obra a ponto de aniquilá-la. Ela funciona como uma espécie de Diagrama (DELEUZE, 2007a , 2007b).

O Diagrama, a partir da abordagem de Deleuze é um conceito, sobretudo, pictórico e que se articula bastante com discussões fomentadas pela pintura. Segundo Deleuze, o Diagrama consiste em um conjunto operatório de traços e linhas, borrado por regiões de manchas assignificantes e não-representativas. Manchas essas, involuntárias, acidentais, sujeitas ao acaso, que permitem o corpo transitar por zonas independentes da lógica e da visão, colocando-o à serviço de outras forças, mais difíceis de serem determinadas pela linguagem comum. Nesse sentido, muito mais do que apontar um único caminho para a obra, a função do Diagrama é sugerir infinitas possibilidades de fatos. É um conceito que ressalta a constante experimentação e reinvenção da obra e não a busca por uma resposta ou uma forma final. O Diagrama se divide em duas etapas: o "caos- catástrofe" e a "organização"32. Ele é paradoxal: abriga o caos de uma indeterminação ao mesmo tempo em que orienta e direciona os materiais no tempo e no espaço. O estabelecimento de uma relação rítmica entre os elementos palpáveis é uma das suas principais funções. É possível dizer que o Diagrama é simultaneamente ordem e catástrofe.

32 Deleuze nos fala de “armazón” (armação), DELEUZE, 2007: 31. 
A catástrofe se opera em momentos de desequilíbrio e de queda. Para se chegar ao pictórico é preciso de um momento pré-pictórico. Esse momento é o caos. Antes da criação do mundo, os átomos se agitam desordenadamente em uma dança cósmica até que haja um encontro químico. O caos lida com um impulso, uma explosão antes da imagem. Senão, não há força para se criar a matéria. O gesto só é despertado na dramaturgia se houver o caos para gerar o material de onde vai emergir.

Nesse sentido, ele lida sobretudo com uma coisa: com o começo do mundo. A cena é o desvirginamento constante do universo. Talvez no caso da performance e de trabalhos com espaços para o improviso isto seja ainda mais claro: tudo parece manifestar-se como se fosse a primeira vez. Contudo, até mesmo em encenações com repetição de estruturas, como coreografias ou partituras psicofísicas, deve haver uma busca pela descoberta. A cada momento cria-se um novo mundo. Ao artista, cabe realizar seu trabalho como se nunca tivesse atuado aquilo antes, como se tudo estivesse sendo encontrado no momento da encenação. Quando isto não ocorre, o trabalho torna-se mecânico, uma mera repetição de um acordo previamente estabelecido. A cena fica só na forma, mas não se entrega ao seu acontecimento. $\mathrm{O}$ único risco que a obra enfrenta é o do tédio ou do constrangimento.

Desse modo, o performer não deve ser encarado nunca como aquele que detém a verdade ou o conhecimento sobre a obra da qual participa. Um trabalho, mesmo que ensaiado, partiturado ou coreografado, não se cria apenas uma vez, antes da estreia, mas a cada encontro. Primeiro na sala de ensaio, no encontro entre os diferentes participantes que a cada dia precisam reconhecer-se novamente e mais para frente, no encontro dos participantes com cada público. Afinal de contas, o que interessa à dramaturgia em questão é o risco que se estabelece na experiência em comum. "Pensar a obra como antiobra na iminência do sempre novo no conhecido. No vivido, todo um presente". (ROCHA, 2012, p. 66).

Não deve haver diferença entre a inteligência do artista e a do espectador. Percebe-se o espectador como atuador da própria história e o ator como espectador do mesmo tipo de história, que é a vida ${ }^{33}$. Isso significa o fim de dicotomias como "artista-ativo" e "espectador-passivo". Há um pressuposto de igualdade, mas não como meta a se alcançar, pois a própria ideia de finalidade já considera a existência

33 Todo esse parágrafo se apropria de forma bastante explícita ao artigo "Espectador Emancipado"(RANCIÈRE, 2007). 
de um desnível. A igualdade na experiência cênica, portanto, deve ser compreendida como ponto de partida e trajeto.

Antes mesmo de afetar uma construção de mundo sobre o qual a obra poderia ou pode se referir, o conceito de catástrofe afeta, no caso da dança, o ato de dançar, no caso do cinema o ato de filmar e assim por diante. O Diagrama como dramaturgia é uma operação sem a qual não se poderia notar a teatralidade do evento teatral. Sua operação é principalmente de desagregação do próprio fazer. É uma catástrofe que se dá no teatro, sobre o teatro. É o que distingue as artes performativas de outras artes.

Repetir a cada dia um corpo que se refaz. A cada vez ser obrigado a reconstruir, sempre diferente. Na medida em que a arte torna-se um ofício, os artistas que buscam o gesto em suas escritas são constantemente desafiados. Afinal, como despertar a força caótica criativa do desconhecimento, a cada dia, durante uma temporada que pode durar anos? Como não ficar apenas à mercê de uma inspiração? Como um artista ou uma companhia reconhecidos escapam às atribuições e características que lhe são dados, sem se fixar a uma código fixo? Como realmente correr o risco e não fingir, fazendo uso de truques já conhecidos? Como trazer a catástrofe para cena, dia após dias, sem nela se perder completamente?

Os artistas, felizmente ou infelizmente, estão suscetíveis ao cansaço, ao desânimo, à tristeza, ao medo, à preguiça e ao desejo de aprovação. Tudo isso faz parte da vida e não precisa ser escondido. Então, por que não ser atravessado por essas influências? Ser alimentado pelos humores, estados e acontecimentos. Utilizálos como pigmentos, nuances de vida para cada experiência. O mesmo vale para o público. Como deixar-se contagiar pelo que quer que seja, em um encontro não só com os artistas e com a obra, mas também com os outros espectadores? Como sobreviver ao constrangimento da presença de um outro diante de si, e da própria presença, na presença de outros, no caso das artes performativas? Como liberar-se um pouco dos smart phones, dos compromissos, dos sacos de pipoca e dos relógios? Como não assistir um trabalho já esperando alguma coisa sobre determinado artista, companhia ou obra? Como desprender-se das expectativas de compreensão, de deleite, de incompreensão, de tédio e simplesmente permitir-se estar em um mundo criado coletivamente no instante da experiência?

Isso se extende à crítica e aos estudos teóricos. Como o discurso pode ser afetado por questões propostas pela obra? Como formular, não respostas ou afirmações a respeito do que é ou não é o trabalho ao qual se faz referência, mas 
novas perguntas e novas imagens? Como pensar em conceitos que ao invés de apaziguar as inquietações, criam novas inquietações?

$\mathrm{O}$ artista, o espectador e a crítica devem ser operadores de gestos. Eles desejam e ao mesmo tempo não desejam a produção de um efeito. Se por um lado dedicam-se a aprimorar suas ferramentas expressivas e perceptivas, por outro, sabem que há algo que não podem controlar. Os efeitos decorrentes de um projeto artístico não são necessariamente conscientes; muitos deles, inclusive, escapam aos participantes. Mas também voltam a eles, lhes provocam, promovem modificações, desvios em cada dia de traçado da sua escrita. Para que esses efeitos possam se manifestar é importante que haja uma forma ou várias formas materiais por onde as forças possam se revelar.

Assim é preciso que a desarticulação do caos seja mediada por pontos de organização, a fim de que a catástrofe não domine a obra a ponto de destruí-la. Pensando cosmologicamente, depois do caos vem a instauração da geometria. O universo se materializa e nele tudo se organiza. É aí que entra a necessidade da instauração de contornos. Algo que pode parecer contraditório, visto que a cena contemporânea lida justo com a diluição desses mesmos contornos. Borram-se e diluem-se as fronteiras. Ainda assim, a dramaturgia necessita de alguma orientação, por mais fluida e inconstante que seja: um tema, um ponto-de-partida, uma duração, um lugar ou até mesmo uma tarefa mais complicada, como a execução de um movimento em um ritmo, enquanto se canta uma canção em outro.

Traçando um paralelo com a pintura, podemos dizer que esse limite é como a armação de um quadro. A moldura ou armação na dramaturgia tem a função de circunscrever as relações espaço-temporais entre os elementos pictóricos dentro de certos limites, amparando o caos-germe para que ele não cresça de tal forma sobre a cena, a ponto de dominá-la. É a partir desse encontro entre o caos-catástrofe e a sustentação, que se revela a cor do gesto, sua nuance, sua tonalidade. Deleuze o utiliza a partir da pintura, mas é possível levá-lo à outras áreas.

A cena também é pictórica na medida em que trabalha com imagens e visualidades. Imagens não necessariamente visuais. Os outros sentidos, audição, olfato, tato, paladar, convocados pela cena são pictóricos na medida em que funcionam como Figuras (conjunto simultâneo de Formas). Lidam com texturas, volumes e temperaturas. E é na interação entre as Figuras e no modo como elas se 
relacionam com a duração do evento cênico, que uma força pulsante nos toca para além da imagem. Algo que no visível ultrapassa o alcance da visualidade comum.

Seria o gesto na dramaturgia algo semelhante às forças a princípio invisíveis, insonoras, sem forma fixa, mas indubitavelmente presentes, como a força do tempo, por exemplo? Seria a dramaturgia um veículo capaz de tornar visíveis forças dessa ordem? Paul Klee diria: "não apresentar o invisível, mas tornar visível” (DELEUZE apud KLEE, 2002, p. 62) ou "não tornar visível o invisível, mas tornar visível o visível” (ROCHA apud KLEE, 2012, p. 23). Nesse sentido, seria a arte responsável por apresentar uma vida que não se encontra na estabilidade da forma? Como apresentar elementos da vida, como a morte ou passagem do Tempo, que não tem uma imagem ou uma visualidade claramente identificáveis?

Há, quem sabe, no trabalho com gesto, a suposição de algo muito grave que está para se revelar, mas que não se revela. As artes da cena criam novas formas de trabalhar com o visível, nos mostrando aquilo que no óbvio não estava à vista. Contudo, as coisas se tornam visíveis e nos arrebatam, mas logo em seguida se escondem, deixando em nós uma espécie de lacuna.

"Pois a Arte, e a escrita dentro dela, é a assunção e a suposição de algo grave e terrível que sempre está prestes a revelar-se e que não se revela, nem se revelará nunca. Basta um gesto feito e eis que se esconde novamente logo ali, para que eu retome sempre às cegas, o fluxo e o sentido do desconhecer ali suposto. Isto é para mim, compor". (ROCHA, 2012, p. 86)

Podemos dizer que trata-se de um elemento corrosivo entre o visível e o invisível. Ele se instaura em contraponto a um modo de vida estruturado à serviço da norma, no qual o poder, de algum modo, se articula com a esfera do visível, considerando que esta qualidade atesta para a existência de um "real". A ciência torna noções como "eu vejo e por isso existe" ou "é preciso ver para crer" bastante comuns. Atualmente, vivemos em uma cultura com forte apelo imagético, na qual as imagens valem até mais do que as palavras. Ao dar Figuras para potências que são invisíveis, no sentido literalmente ótico, o gesto abre caminho para um outro tipo de olhar, uma outra relação com a visualidade. "Ver", não somente com os olhos, mas com outras partes do corpo. "Ver" com a pele. Nesse sentido, há uma relação direta entre o invisível e o indizível. O que se enxerga pode ser descrito e circunscrito, enquanto aquilo que não pode ser visto ou dito, se coloca em uma zona desconhecida, inapreensível, subversiva. Uma dramaturgia potente é aquela que encontra-se 
carregada de pontos não reconhecíveis, não identificáveis, que não se encaixam em uma única explicação, mas que se articulam com o universo de reconhecimento do visível. Só são possíveis porque visíveis. E invisíveis.

É importante chamar a atenção para a influência dos estados como material de trabalho primário nas Artes Cênicas e recurso a ser desenvolvido pelos artistas da cena. Mas afinal de contas, o que significa "estado"? Sentimentos e pulsões que agem sobre a forma? A interioridade ou a psicologia da forma? O elemento invisível que dá sentido a uma relação formal? Artaud diz: "O drama não evolui entre sentimentos, mas entre estados de espírito, ossificados e reduzidos a gestos - esquemas" (ARTAUD, 1999, p. 55)

Em uma residência direcionada à atores e bailarinos, ministrada pelo corógrafo João Saldanha, em janeiro de 2014, no Teatro Poeira (RJ) ${ }^{34}$ foi proposto um exercício que suscitou uma discussão entre forma e estado, corpo visível e força invisível. Inicialmente, João provocou alguns participantes a se colocarem em cena em um "estado de espera". Mas o que seria um estado de "espera"? Haveria uma forma para a espera que correspondesse ao estado solicitado? Haveria um olhar para a espera, uma respiração? Esperar estava ligado a uma sensação de passividade ou de atividade? Esperar era relaxar ou estar com o corpo atento para a reação?

Aos poucos, o grupo foi percebendo, tanto pela execução da proposta, quanto pela observação, que havia muitas possibilidades para a espera. Mas qualquer que fosse a possibilidade colocada, ela dependia da interação entre a forma física e uma afecção sensível, mais difícil de ser apreendida. Muitas vezes tentava-se alcançar o estado por uma forma mais imediatamente reconhecível, como uma postura relaxada, braços cruzados, olhar no horizonte. Mas nem sempre a forma trazia a sensação do estado. Todos os participantes podiam opinar sobre a presença da espera. As opiniões nem sempre eram unânimes, até por que o estado, como companheiro do gesto, não é algo que possa ser apreendido de uma maneira direta e definitiva. Aliás, se a obra pode ser lida de diversas maneiras, isso já é uma prova que há alguma coisa para além da circunscrição do visível. Não obstante, apesar de sempre haver espaço para a discordância, em alguns momentos, o estado parecia chegar mais perto para a maioria do grupo. Às vezes isso ocorria quando algum observador sugeria ao voluntário do exercício uma mudança na forma física. Outras vezes, a espera só parecia se

\footnotetext{
34 Residência da qual faço parte, realizada entre dezembro e março de 2014.
} 
manifestar depois que o participante passava alguns minutos em uma determinada forma e a espera se tornava "real". Não havia fórmula.

Em seguida, João solicitou que o grupo observasse uma das participantes, a participante Z, que segundo ele estava “em espera”, com as costas apoiadas na parede e as mãos na cintura. Ele pediu que o participante $X$, tomasse o lugar de Z, tentando imitá-la. X seguiu a orientação. O que o grupo constatou é que $\mathrm{X}$ se aproximou muito da geometria que lhe serviu de modelo, mas o estado parecia diferente. Depois de um tempo naquela posição, ouvindo os comentários do grupo, parece que $\mathrm{X}$ foi "entrando" no estado de espera, se acostumando a esperar. Logo, foi a vez de Y repetir o exercício. Y tomou o lugar de $\mathrm{X}$ na parede. Apesar de ter as costas na parede e mão na cintura, Y compunha uma forma com o corpo muito diferente das anteriores (talvez por conta da diferença de suas dimensões. Y era muito menor que seus companheiros). O grupo remarcou que apesar da proporção geométrica do corpo ser diferente, o estado de $\mathrm{Y}$ se aproximava bastante afetivamente dos estados anteriores.

Assim, João Saldanha sugeriu que o estado era como um "extra corpo" para além da forma. Essa percepção deu corpo ao estado (e aqui pensaremos também na potência, na presença e sobretudo, no gesto). Se por vezes o estado é confundido com uma noção de interioridade, de atribuição de característica à forma-corpo ou uma força quase espiritual que o "incarna", esse exercício deu a ver que ele é também corpo, apesar de à priori ser um corpo informe, sem cor, sem cheiro e sem som permanentes. Talvez por isso, sua relação com o visível possa se dar a partir de infinitas formas. Entretanto é preciso que haja matéria para que o corpo do estado possa se apresentar. No exercício proposto por João Saldanha, o estado precisou de uma forma, ainda que diferente da inicial para se revelar.

Nenhuma dramaturgia é feita só de estado ou só de forma. Invisível e visível não são categorias opostas, apartadas, mas complementares. É na interação entre visível, forma, invisível e estado que reside o caráter singular de cada obra. Às vezes é preciso alterar o estado para reorientar o sentido da forma. Outras vezes é o oposto que se dá. A forma sugere uma leitura diferente para a sensação. No caso de uma dramaturgia de gestos, a força invisível da potência e da presença, lida com formas e estruturas maleáveis e reconfiguráveis em relação à intensidade e à qualidade da presença sensível. Mais do que um estado que reitere a "opinião" da forma, o que 
interessa ao gesto é a discordância não-antagônica entre os elementos que compõe a Figura, como veremos em breve.

O acontecimento cênico possui dobras, zonas que não podem ser vistas, mas que fazem parte dele e que de algum modo sabemos que são fundamentais para a sua constituição, mesmo que não se coloquem explicitamente aparentes. Como a ideia de roupa, visitada no capítulo anterior. Existem fendas, costuras, mangas, que não podemos ver quando a roupa está dobrada sobre a estante, mas que sabemos que a constitui e que são fundamentais para sua materialização. Essas costuras nãoaparentes tem a ver com o processo de materialização da obra. Estão relacionadas às descobertas descartadas ao longo da criação, às descobertas transformadas, às descobertas porvir, aos acordos feitos entre os participantes que não são explicitados para o público, ao segredo que cada um leva para o evento performático, seja espectador, seja artista.

A partir da disposição e da combinação dos materiais em um determinado suporte se produz uma potência que escapa aos limites do suporte, atingindo dimensões exteriores à moldura. Certamente que em algumas obras essa relação com os contornos se faz mais ou menos presente, mais ou menos fluida. Todavia, o Diagrama precisa ser minimamente operatório e controlado para liberar a passagem dessas forças, de fora e para fora. De outro modo, a catástrofe pode acabar inundando tudo. "Nem todos os dados figurativos devem desaparecer, e, sobretudo, uma nova figuração, a da Figura, deve surgir do Diagrama, conduzindo a sensação, ao claro e ao preciso". (DELEUZE, 2007 a, p. 112)

Mas qual a linha tênue que separa a limitação que ampara a inspiração criativa de uma limitação infecunda? Os contornos na Dramaturgia do Gesto convidam os participantes a ultrapassá-los. Quando consegue isto, uma potência se apresenta. E é nesse instante ou nessa sequência de instantes, que a presença se faz marcante.

\footnotetext{
"Articular-se diante das limitações: é aí que a violência se instala. Esse ato de violência necessária, que de início parece limitar a liberdade e diminuir as opções, por sua vez traz muitas outras alternativas e exige do ator uma noção de liberdade mais profunda". (BOGART, 2011, p. 53)
}

Retomando a ideia de cartografia: a organização na dramaturgia do gesto não constitui uma geografia fixa. Ela oferece pontos de "apoio", orientações móveis para que os envolvidos na experiência da cena não se percam completamente. Mais do que uma amarra, essas molduras funcionam como balizas, formas dentro das quais as 
"novas correntes infindáveis de força vital, de vicissitudes e ligações emocionais com os outros atores"(BOGART, p. 51) trafegam sem o risco de perderem-se ou dissiparem-se por um espaço ilimitado.

"O perigo da coreografia é extirpar do movimento, a dança. A maravilha da coreografia é devolver à dança o movimento; é devolver a dança ao movimento." (ROCHA, 2012, p. 80)

A dramaturgia é um caminho sobre o qual a encenação pode se mover. $\mathrm{O}$ modo como se atravessa esse caminho - correndo, marchando, em câmera lenta, saltitando - é que diz respeito a reinvenção do gesto. A dramaturgia propõe uma estrutura material que possibilita a fluidez. Dá o chão. Mas conforme atravessamos, dia após dia, o impacto dos nossos corpos causa pequenas erosões no caminho. A terra se espalha, modificam-se os relevos, novas plantas crescem, outras morrem. Trechos que antes eram livres, agora aparecem interditados. Abrem-se clareiras. Ao longo do processo de uma montagem, os caminhos da dramaturgia se refazem a todo segundo e assim é preciso fazer novas escolhas, optar por outros rumos, decidir qual direção tomar no meio de uma encruzilhada imprevisível, visitar continentes que já existem, criando novas paisagens.

Escrever é tomar decisões. No caso da dramaturgia, por exemplo, colocar um ator no centro do palco destrói todas as outras opções de localização. Durante os ensaios, os artistas devem se questionar: o que será que fica na cena e o que será que sai? Como aquilo que fica se apresenta? Quais as formas selecionadas e quais os procedimentos estruturais devem ser utilizados para se chegar a elas? As escolhas de algum modo lidam com uma decisão e com um um rigor. Há uma crueldade na escolha. Afinal, Quando o encenador, o dramaturgo, o coreografo ou o performer optam pela escolha de um movimento, por uma relação espacial ou por uma dinâmica rítmica entre os corpos, eliminam todas as outras escolhas possíveis. Quando alguém escolhe, desescolhe todo o resto. O que sobra como dramaturgia é o resultado de diversas descobertas descartadas. É uma violência que lida com infinitas mortes. "A decisão é uma agressão contra a natureza e a inércia" (BOGART, 2011, p. 63). Mesmo uma escolha aparentemente pequena, como definir o posicionamento de uma cadeira e a sua angulação, pode parecer uma violência diante daquilo que se apresenta como o fluxo e o curso livre da vida. Há um tensão entre o finito e o infinito: ao 
mesmo tempo em que a escolha dá destino à um sem fim de possibilidades, estando sob a "pressão do finito" (KIFFER, 2003, p. 154), ela lida com a inquietação e com a lembrança de que aquele é só um caminho de uma obra que está sempre por se fazer.

\footnotetext{
"Antes de serem metáforas/significados, o infinito e o finito seriam campos de forças, vetores, linhas que se perfazem na busca de uma realização que toca sempre o irrealizável, daí também sua apreensão corpórea, física da linguagem, seja ela cênica, escrita ou pictural”. (KIFFER, 2003, p. 154)
}

A escrita cênica é um emaranhado de linhas e experiências em combate. $\mathrm{O}$ ponto-de-vista do artista é um direcionamento não civilizado de forças. O poeta, ao direcionar uma força, ao atribuir matéria e corpo às intensidades, corre o risco de se aproximar da soberania. E aí reside o perigo, visto que a soberania muitas vezes lida com um posicionamento de instâncias de poder. Como não cair na mesma natureza de soberania da ciência, da soberania política ou da soberania religiosa (KIFFER, 2003, p. 154, 155)? Como o artista pode decidir, quais linhas serão utilizadas para dar forma ao infinito irrealizável, sem cair nesse tipo de soberania?

\footnotetext{
“Nesse ponto é onde o 'jogo' torna-se perigoso e não somente 'prazeroso' (...) Como temos visto, esta inclinação soberana, sua direção implacável, será a base mesma para a sua ${ }^{35}$ formulação de um princípio de crueldade, onde a visão sangrenta do mal não é senão sua face mais superficial, epidérmica e por isso mesmo, mais amena". (KIFFER, 2003, p. 154, 155)
}

Se por um lado, a crueldade da determinação de uma escolha, abarca o risco de se acabar momentaneamente com algo muito precioso que surgiu durante um processo espontâneo, por outro, a cada destruição de uma descoberta, o artista não a exclui completamente. Ele se apropria do material descartado, transforma, condensa, o torna mais substancial. Investe no aprimoramento e no desse encontro entre o risco do desconhecido, desse momento antes da escolha em que tudo é possível, e o traçado da escrita. As escolhas da dramaturgia, ao contrário do que pode parecer, tem mais a ver com a crueldade de ter que dar corpo ao infinito do que com a soberania certeza. As opções necessárias para que o trabalho condense sua potência investem na dúvida como chama fundamental para que o projeto se mantenha vivo e pulsante. E ironicamente, talvez a dúvida resida justamente na busca por uma certeza. Mas não

35 Referência à Artaud. 
uma certeza legítima. O caminho de uma escrita dramatúrgica mata as certezas autênticas para dar espaço a certezas momentâneas.

Em algum momento o artista "escolhe" um elemento que precisará ser mantido com o mesmo frescor de quando foi encontrado. Se o estímulo que o levou àquela opção não estiver mais presente é preciso que ele encontre uma nova espontaneidade, talvez até mais profunda para a forma estabelecida. Estas formasarmações atuam como acordos de linguagem entre os artistas, entre artistas e público, entre o público. Uma linguagem que não se apresenta como limitação. Uma linguagem de muitas línguas que fomenta o diálogo, a interação, a conversa; com seus possíveis encontros e desencontros, acordos e desacordos, afinidades e incompreensões, gritos, sussurros e descobertas.

É importante marcar que quando falamos em espontaneidade, não estamos necessariamente dizendo que há imprecisão. Não quer dizer que um movimento ou uma palavra tenham que ser frouxos ou sem tônus. Pelo contrário, trabalha-se o corpo para ser preciso no desconhecido. Trata-se da possibilidade de repetir um gesto que por não ser mecânico, se repete sempre de uma nova forma. A liberdade muitas vezes se cria a partir da precisão, que aliás, pode ajudar a obra a se tornar mais condensada e substancial. Os movimentos de uma coreografia podem ser exaustivamente ensaiados e partiturados e ainda assim, constantemente reinventados, no que diz respeito àquilo que o torna "aceso". A técnica auxilia mais do que limita, sobretudo na dança, que muitas vezes lida com saltos e quedas. O bailarino que faz disso um ofício não pode se machucar. É importante que ele saiba saltar e cair, mas colocando no salto e na queda, que tanto conhece, algo de misterioso e desconhecido.

Saber escolher é algo que diz respeito à técnica. A dúvida também. Como ser preciso naquilo que não se sabe? Ou então: como se espantar precisamente com aquilo que se faz todo o dia? Como reencontrar a fagulha que se acendeu em um primeiro improviso ou nos primeiros dias de temporada? No caso de estruturas performativas, com muita margem para o improviso, como orquestrar o acaso? Como ser um maestro das circunstâncias? Como responder aos estímulos do parceiro e do público? Se a "língua menor" do gesto é uma língua que depende, ao mesmo tempo que faz gaguejar a "língua maior" dominante, como se aprofundar na gagueira? É possível treinar-se para a dúvida e o desconhecido? Por que se treinar para a dúvida e o desconhecido? 


\begin{abstract}
"Mesmo que faça algum sentido, essa dramaturgia da dúvida não perdura; ela não convida a linhagens. Dúvida alguma cria parâmetros, escolas, tendências, estilos, seguidores, ou coerência entre filmes desconexos. Seu gesto não ultrapassa o intento da pergunta, o toque da perturbação, do estranhamento do instante, volátil, em que algo foi colocado em xeque. A dúvida não se resolve nas contorções da dialética, nem se conforma com roupagens niilistas. É como a escada de Wittgenstein: seus degraus desmoronam enquanto escalamos, eles se anulam, não se sustentam, não criam sistemas, mas atos, gestos, instantes. É no seio dessa névoa, prenhe de imprecisões provisórias, que a dúvida aponta para algo novo e indefinido. Algo inominável, invisível, impronunciável”. (GONÇALO, 2013).
\end{abstract}

Segurança não gera entusiasmo. Basta pensar no circo. Olhemos pois, para o funâmbulo que se equilibra sobre um fio. Sabemos que ele tem técnica e domínio do seu corpo naquela linguagem, do contrário, não estaria pondo em risco a própria vida. Seria um suicida, apenas, e não um artista. Ao mesmo tempo, ele não tem o controle total da situação. Pouco importa que tenha se mantido tantas apresentações em equilíbrio. Ele sempre corre o risco de uma queda fatal. E é por isso que o assistimos: para celebrarmos a dança entre técnica e descontrole, entre domínio do corpo e o risco da morte.

$\mathrm{O}$ artista do gesto, qualquer que seja a linguagem utilizada, possui alguma coisa de funâmbulo. Ele lida com o risco da morte porque não tem controle de tudo, porque através dele passam fluxos de uma força que não consegue dominar. Não obstante, ele trabalha na maioria das vezes a partir da técnica. Não necessariamente uma técnica reconhecida como a do balé ou a do butô, mas um conjunto de técnicas que vai adquirindo ao longo da vida, que vão desde de um treinamento da voz e do corpo, passando por um repertório de referências e de contato com aquilo que lhe inspira. Um treinamento afetivo ou um "atletismo afetivo", mais ou menos como o que nos fala $\operatorname{Artaud}^{36}$. O atleta afetivo desenvolve uma espécie de musculatura física dos sentimentos, percebe a alma como um novelo de vibrações e busca conhecer "o segredo do tempo das paixões, dessa espécie de tempo musical que rege seu batimento harmônico" (ARTAUD, 199, p. 154).

Trata-se de um aprendizado que se utiliza do instinto para suprir a ausência de uma noção que não se pode definir, pois seu aprendizado nada tem a ver com a aquisição de um conhecimento absoluto. Um funâmbulo não pode parar muito tempo sobre a corda-bamba, senão ele cai. A primeira coisa que deve aprender é que o caminhar é fundamental para a sua sobrevivência. O deslocamento, para nós, aparece

\footnotetext{
36 ARTAUD, Antonin. “Um atletismo afetivo". In: O Teatro e o seu Duplo”. São Paulo: Martins Fontes, 1999, p. 151-161.
} 
menos ligado à ação produtiva e funcional e mais a uma relação sobre o conhecimento que não se encerra. Uma aprendizagem que se re-atualiza sempre no risco.

A partir da percepção da importância de um treinamento e da constante coleção de repertório, coloca-se mais uma questão: pode haver gesto na proposição de um artista estreante ou de um artista que se dedica muito pouco a seu atletismo afetivo? O gesto às vezes aparece assim, como que por acaso, por sorte ou desejo, onde menos se espera. Além disso, o artista estreante não é assombrado por muitos vícios e clichês porque eles não o antecedem. Entretanto, para que ele continue sendo um operador de gestos, sem depender do fator da sorte ou de um talento inato e sem futuramente cair na armadilha dos próprios clichês é preciso aprimorar os instrumentos que vão de encontro a eles. Sua técnica reside em desenvolver caminhos para novas descobertas, ferramentas para a construção de infindáveis dramaturgias.

\begin{abstract}
"Le danseur est dont aussi le géomètre immédiat de son corps en mouvement. Il ne crée pas ses rhizomes à l'aveugle ou, si j'ose dire, par-dessus la jambé. À chaque moment il $<<$ doit mesurer lignes, silences, zig-zags et courbes rapide avec un sixième parfum et de géometrie, sans jamais se tromper de térrains comme le torero dont le coeur doit battre dans la nuque du taureau ${ }^{37,}$. (DIDI-HUBERMANN, 2006, p. 37)
\end{abstract}

Tanto a técnica, quanto a dramaturgia funcionam como boias espalhadas ou pontos de ancoragem para que os participantes da experiência cênica não se percam e nem se afoguem no alto-mar da convivência. As estruturas da dramaturgia, servem para que não fiquemos suscetíveis a alterações drásticas de qualidade e intensidade, a cada dia de ensaio ou apresentação. Como quem tem que atravessar um rio e escolhe ir pisando nas pedras mais firmes para não ser arrastado pela correnteza. A dramaturgia se faz aos poucos: primeiro se pisa em uma pedra, depois na outra. É no perigo entre uma pedra e outra que se faz o gesto. Sem a estabilidade de uma superfície o corpo precisa reinventar seus eixos. A posição ereta não é mais a única opção. Abrir um espaço para a queda. Evocar a queda sempre que possível, mas não para ceder a ela totalmente e sim, para vencê-la. Nessa luta entre a queda total e a estabilidade da posição ereta existem vários centros descentrados. Há um perigo real de se estar entre o corpo do homem e o corpo "inumano", que não se equilibra sobre os dois pés, que rasteja. Tanto o corpo ereto e equilibrado, quanto o corpo estendido

37 Minha tradução: O dançarino é também o 'geométra' imediato do seu corpo em movimento 
já foram muito explorados na arte. A dança contemporânea busca esse ponto que não é um nem outro. O gesto acontece no momento em que estamos com um dos pés suspenso no ar. Às vezes, os dois pés. Este é o desafio. Correr o risco de escorregar no limo, de pisar em falso ou pisar em uma pedra bamba e se esvair queda abaixo, na violência de uma cachoeira, como um tronco de árvore.

Sim, porque sempre podemos cair. Até mesmo o funâmbulo mais competente pode despencar e aí, adeus gesto! Não basta seguir as pedras do rio, os caminhos da trilha, o fio esticado da corda-bamba. Não basta ser um performer bem preparado e apenas seguir a dramaturgia. Nada é seguro ou está dado de antemão. Nem todo o caos é capaz de gerar um gesto. Sempre se pode fracassar. Nenhuma dramaturgia é garantia de gesto, sempre se pode escorregar. Essa é a graça. Às vezes algo não acontece, simplesmente. E isso não tem a ver apenas com vontade, com competência ou com dedicação. Até porque "gesto" não é uma categoria de juízo de valor. Ele não é selo de qualidade para nenhum projeto artístico. Quantos trabalhos já assistimos que são belíssimos, tecnicamente perfeitos, mas que por alguma razão não nos instigam em relação ao perigo; como se, ao invés de uma corda-bamba, os artistas desfilassem em uma parada alegórica de "paixões medianas" sobre uma larga pista plana de concreto? Quantas propostas a princípio bastante arriscadas também não tropeçam no meio do caminho e se perdem sem deixar vestígios? Quantas vezes o artista tem certeza de que está em uma determinada vibração, mas ainda assim o público não vibra com ele? E o contrário: quantas vezes o coletivo tem certeza de que aquele foi um dia péssimo e no entanto, o público vibra?

Apesar de nada estar garantido, o artista pode de algum modo se precaver, treinando e reconhecendo o seu principal instrumento, o corpo. $\mathrm{O}$ atleta afetivo tem chances maiores de alçar voos mais altos em seus saltos, alcançando assim, gestos de grandes paixões, sem se espatifar, sem se contundir. Ele tem mais repertório e experiência para se lançar sobre diferentes pedras, sobre diferentes dramaturgias e seus respectivos contornos.

Antes de dançar, muitas coisas já se passaram. Que luta deve se instaurar para começar a dançar? Que fantasmas de corpos passados devem ser esquecidos, quais devem ser resgatados? Quando se dança é preciso lutar contra os clichês. Os clichês estão sobre o palco até mesmo antes de se começar a ensaiar. Para que se crie a partir da mancha e do caos nas linhas que o compõe é preciso se afastar o máximo daquilo 
que já estamos acostumados e viciados. O Diagrama promove uma zona de limpeza dos clichês.

Para que os elementos da cena não fiquem desvitalizados no palco é imprescindível que haja um componente de indefinição ${ }^{38}$. Os participantes trabalham a precisão para serem precisamente indefinidos. A indefinição remove um posicionamento confortável diante da obra e faz o público questionar o modo de narrar. "Ser ou não ser, eis a questão". Qual o sentido de dizer mais uma vez essa frase em cena? Ela já não seria potente o suficiente através da leitura do texto? Pegar uma xícara de café, sentar-se numa cadeira, fumar um cigarro. Essas ações já foram e ainda são feitas tantas vezes que para se destacarem, para pulsarem, precisam ser realizadas de modo que não sejam reconhecidas completamente.

Propõe-se uma encenação que não descreva completamente um único significado do tipo "isso quer dizer isso". A busca é pelo inesperado e uma ferramenta possível para se trabalhar com a indefinição ou a imprevisibilidade é a "discordância". A complexidade da vida está na coexistência de estados distintos. Diferentes quereres, diferentes direções, no mesmo espaço, no mesmo encontro ou na mesma pessoa. Ao mesmo tempo, no mesmo corpo: a paixão e a indiferença. "A oposição, ou dialética, estabelece sistemas alternativos de percepção. Cria espaços de choque onde o insight pode ocorrer". (BOGART, 2011, p. 62). Essa oposição marca um conflito nos corpos que se recusam a pertencer a uma categoria, a um único sentimento, a um desejo apaziguado e definível. O gesto na dramaturgia aparece para romper com uma construção paradigmática de mundo, que coloca as contradições da vida em corpos separados, tentando categorizar, definir, acalmar o homem, atribuindo a ele um único lugar. O gesto transforma a forma a fim de despertar uma multiplicidade de sentidos e sensações que se deslocam e se transformam o tempo todo.

Apesar das sensações serem imprescindíveis para se abordar esta dramaturgia de presença, também é importante perceber que não se trata somente de uma dramaturgia de sensações. Afinal, o tempo inteiro somos atravessados por sensações, inclusive no centro das instituições normativas. Até mesmo a indiferença é uma sensação. Todavia, o que interessa nas sensações tocadas pelo gesto são as sensações de desarticulação da unidade.

38 A partir de Anne Bogart (BOGART, 2011, p.62). 
A unidade é um problema a ser enfrentado. A produção ou a recepção de uma dramaturgia deste tipo não reconhece um só corpo, um só indivíduo, um só sentimento, um só personagem, um só tema, uma só trama, nem somente uma significação. Variabilidade e multiplicidade são noções fundamentais. Há no Diagrama, a possibilidade de implantação de eixos de todos os tipos. Conexões ao acaso, que geram afetos improváveis, infinitos. Em algum momento, escolhe-se fazer determinado movimento, mas este movimento não se encerra em si mesmo; ele abre caminho para infinitas leituras. Em um evento de dança, manifesta-se o efeito de danças infinitas, a possibilidade infinita de coreografias e corpos. "O gesto é precisamente o que une de maneira teatral e assignificante as atitudes do corpo"39. (DELEUZE, 2007 b, p. 55)

Não há personagem ou identidade fixados aos corpos. O ator não é intérprete porque ele não interpreta nada e nesse sentido, deve ser encarado como performer, na medida em que oscila entre o simbólico, o imaginário e o real "aqui e agora" da experiência. Ele não compõe um personagem individual, ele experiência o processo de descoberta das possibilidades de pulsões. Nesse sentido, nem chega a ser um sujeito fragmentado, pois a própria ideia de fragmento pressupõe uma unidade. Hamlet não é um sujeito individual, mas o ponto de convergência de uma multiplicidade de paixões. "Dançar é devir outro". (DIDI- HUBERMANN, 2006, p. 24). É se perder como sujeito no espaço e no tempo dos movimentos. Aquele que dança deixa, por alguns instantes, as posturas físicas que utiliza socialmente sob uma identidade. Será que não é por isso que necessitamos tanto dançar? Pela possibilidade de descansar de si, ainda que parcialmente, e finalmente ser vários? Pela possibilidade de ser qualquer um? Pelo processo de criação e experimentação de um outro ser?

Uma dramaturgia de gestos se orienta a partir da relação entre coletivos de seres com outros seres e com suas respectivas potências, fragmentos e espaços. Não existe "meu corpo", "minha dramaturgia", "minha interpretação" mas o encontro de diversos corpos desfeitos de si, envolvidos na experiência.

Ainda assim, os gestos precisam de estrutura, de sustentação para o corpo. Pensemos pela perspectiva do Corpo sem Orgãos (DELEUZE; GUATARRI, 1996, p. 9-31). A partir de Deleuze e Guatarri, podemos perceber um corpo, que possui sim,

\footnotetext{
${ }^{39}$ Tradução minha para "el gestus es precisamente lo que une de manera teatral y assignificante las actitudes del cuerpo".
} 
orgãos. No caso da dramaturgia, são eles as balizas, as molduras, os pontos de apoio e suas incontáveis possibilidades de combinação e atravessamento de afecções. O corpo da dramaturgia em questão é composto por orgãos de infinitas naturezas: orgãos de estrutura, de linguagem, de intensidade, de materialidade, de espacialidade, de estados, de dinâmicas, entre outros tantos possíveis. Todavia, eles estabelecem um outro tipo de relação, que antecede a extensão do organismo e a estratificação dos orgãos de acordo com funções previamente estabelecidas.

"Percebemos pouco a pouco que o $\mathrm{CsO}$ não é de modo algum o contrário dos orgãos. Seus inimigos não são os orgãos. O inimigo é o organismo. O CsO não se opõe aos órgãos, mas a essa organização dos orgãos que se chama organismo". (DELEUZE; GUATARRI, 1996, p. 21 )

O organismo, na perspectiva de Deleuze e Guatarri, diz respeito a um modo de lidar com o corpo através de formas, funções e ligações hierarquizadas e tem como objetivo extrair uma utilidade. No corpo humano, por exemplo, a função do organismo "coração" é bombear o sangue, a fim de que ele circule e oxigene as outras partes do corpo. Já no campo institucional, a função de um organismo legislativo tem como prerrogativa a elaboração de normas de direito que são aplicadas à sociedade, relacionando demandas e administração pública, através de leis e de determinados

julgamentos. $\quad \mathrm{O}$ organismo tem propriedades pré-estabelecidas e lida com a ideia de um corpo "saudável", divido em partes "inteiras" e "completas". Ele não aceita contaminações, esburacamentos ou reconfigurações constantes que o desviem de sua função organizadamente produtiva. Ele tenta a todo o custo eliminar as lacunas, preenchê-las, a fim de alcançar uma inteireza. Ironicamente, os discursos dos organismos são eles mesmos compostos por lacunas. O que dizer do discurso religioso, médico, legal, entre outros? Qualquer modo discursivo que se direcione a uma única verdade já se apresenta automaticamente esburacado, visto que a vida não compreende este tipo de generalização. O gesto desestabiliza os modos de discurso em questão, torna visível as falhas escondidas. Ele nos faz ver que a ideia de organismo é contrária a ideia de corpo. Afinal de contas, o corpo não é um arquivo de escritório de funções claras e úteis. Somos seres vivos, pulsantes e não objetos de organização. Sim, tentam nos fazer funcionais. Nós mesmos tentamos ser funcionais, produtivos, úteis como se isso garantisse algum tipo de inserção na vida em comum. 
"Você será organizado, você será um organismo, articulará seu corpo- senão você será um depravado. Você será significante e significado, intérprete e interpretado senão será desviante. Você será sujeito e como tal, fixado, sujeito de enunciação rebatido sobre um sujeito de enunciado - senão você será apenas um vagabundo". (DELEUZE; GUATARRI, 1996, p. 22)

A necessidade de significância dos organismos está muito entranhada no nosso corpo, assim como na nossa construção como sujeito. E sair de uma certa noção de realidade em nós fixada não se faz assim de uma hora para outra. Aliás, talvez nem totalmente. Para desarticular o discurso dos organismos é preciso manter alguma coisa dele. Pequenas porções de significância e de interpretação, alguma coisa que seduza e ative nossa compulsão interpretativa para opor o sistema ao próprio sistema; descobrir as falhas, a partir da própria ferramenta. Como uma "língua menor" que abala a linguagem normativa a partir dos próprios elementos que a constituem, a subjetividade transita na realidade dominante. "Conectar, conjugar, continuar: 'todo um diagrama' contra os programas ainda significantes e subjetivos". (DELEUZE; GUATARRI, 1996, p. 24).

Os momentos de "gesto" na dramaturgia são responsáveis pela desarticulação de estruturas mais rígidas e propõem no seu corpo-matéria, infinitos arranjos e pontos de vista. Mesmo uma dramaturgia que opte pela valorização do fragmento, seus “orgãos” não são compreendidos como partes totalitárias, unilaterais e funcionais. Trata-se de uma escrita cênica que não serve para nada. É antiprodutiva. Ela não significa, não traz uma mensagem, uma história, uma lição. No caso das artes performativas, nem ao menos constituem um objeto para se levar para casa e abandonar na estante. Aliás, eis a razão pela qual escolhemos uma abordagem pela dramaturgia do gesto e não pela dramaturgia da ação ou do movimento.

A dramaturgia da ação preza pela organização do espaço, no qual os recursos são utilizados para formar um conjunto completo, direcionado à produção de uma finalidade e de uma totalidade. A ação lida com a produção de um efeito. Por contrapartida, em uma dramaturgia observada pelo viés do gesto, o corpo não se acomoda no estatuto de um produto final. Cada postura, cada movimento, carrega somente a certeza de que deve lutar contra a forma definitiva. Durante o evento performativo, e não antes, o corpo surpreende à si mesmo dentro das suas possibilidades. Cansada da significação mais "adequada" e da interpretação "correta", a dramaturgia do gesto se faz nômade, sempre em movimento de transformação. Esse 
nomadismo nada tem a ver com o excesso de movimentação na dança ou com uma pirotecnia na cena. Afinal, o corpo parado no espaço pode promover "deslocamentos" de outra ordem, ainda maiores.

O corpo sem individualidade fixa foge ao diagnóstico; é um corpo da experimentação, cujos orgãos se colocam para além da sua função mais obviamente reconhecida. Os olhos servem só para enxergar, as pernas só para andar, a boca só para comer? "Por que não caminhar com a cabeça, cantar com o sinus, ver com a pele, respirar com o ventre (...)?” (DELEUZE; GUATARRI, 1996, p. 11).

Em termos de dramaturgia podemos pensar para além das funções: a luz não existe simplesmente para destacar o espaço e o cenário não é apenas a materialização ficcional de um lugar ao qual se refere. Indumentária, iluminação e cenário não são adereços secundários da encenação. Eles são criações tão importantes quanto as coreografias ou qualquer outro elemento. Não obstante suas localizações e funções são móveis. Além disso, também é possível pensar que o cômico não serve somente para fazer rir ou criticar, o grito para grifar ou o choro para lamentar.

Como pensar em um texto que ilumine, uma cenografia que se faça escutar ou um movimento que sirva como uma roupa? Como pensar em um sussurro que seja um grito, uma graça que emocione e uma tragédia que nos faça gargalhar? A dramaturgia do gesto é uma escrita descentrada que almeja a organização dos materiais cênicos com o mínimo de hierarquia possível. Isso não significa que não se destaquem certos pontos, certas opiniões, certas materialidades de cada obra. Mas aquilo que está em foco não tem mais valor do que aquilo que não está. As potências se distribuem de maneira desigual no corpo-dramaturgia. Desta desigualdade resulta a sensibilização de um determinado orgão, a de outro e a inoperância de um terceiro. Tornar sensível relaciona-se ao foco que se dá a um elemento da escrita cênica, que pode ser, por exemplo, desde um elemento como o movimento do corpo ou até mesmo a qualidade deste movimento (se ele é mais direto, mais ondulado, mais expansivo, mais contido, mais fragmentado); pode ser a métrica das frases de uma fala (o ritmo, a divisão das sílabas, as rimas), como também a maneira como as cenas se articulam com as atmosferas.

Apesar de promover uma cisão, dificilmente o gesto se desenvolve a partir de uma desarticulação grosseira. É muito tênue a linha que separa um gesto realmente político de um evento performativo de qualquer natureza que se diz político, mas que nos soa "datado" (ou rapidamente se torna) por tentar desarticular os orgãos de modo 
muito direto e brusco com as questões de sua época. A ruptura do gesto pode ser muito profunda sem ser escancarada. Se como já vimos na primeira parte, a "potência" não necessariamente está vinculada ao "ato" é importante também não confundi-la com uma ideia de força bruta. Na maioria das vezes a sutileza pode ser muito mais potente, visto que a "força pela força" pode ser em vão, ou tão intensa, a ponto de ser destrutiva. É o caso do caos que corrói as linhas que estruturam o seu Diagrama. A tensão excessiva não deixa a energia da presença fluir. Ela retém a energia.

\footnotetext{
"Não se pode olhar diretamente as grandes questões humanas assim como não se pode olhar diretamente para o sol. Para encarar o sol, é preciso olhar ligeiramente do lado dele. Entre o sol e o ponto que você está olhando fica a percepção do sol. Na arte e no teatro usamos a metáfora como "essa coisa ao lado"”. (BOGART, 2011, p. 62)
}

A cena é um veículo para a criação de novos mundos e de novos regimentos sobre esse mundo através de "ações periféricas e ambíguas" (PAIS, 2010, p. 93). Um gesto abre caminho para outro gesto, um projeto artístico influencia outro projeto artístico, e pouco a pouco vai-se modificando o mundo, mesmo que a modificação do "mundo" não implique na dissolução total das instituições, mesmo que a transformação se dê apenas em alguns homens, que em contato com outros homens vão transformando suas relações até que, quando menos se espera, alguma coisa se modifica completamente.

"Reversão segundo a qual é a arte que oferecerá à vida a qualificação do gesto a partir do seu viver específico - corpo incandescente, corpo terrível- escavando nela um outro modus vivendi, mais potente, capaz de ação política, portanto". (ROCHA, 2012, p. 53)

A potência, mais do que tudo, tem a ver com o engajamento e com o envolvimento dos participantes (artistas, público, crítica) em um determinado projeto. Esse engajamento, que não necessariamente se vincula à adoção de uma causa é responsável pela irradiação de múltiplas intenções. Trata-se da emanação de desejos e de vislumbramentos que tocam os sentidos. Tudo isso pode ser feito aos poucos. Às vezes os efeitos do gesto só se fazem notar muito tempo depois. Outras vezes, nem sabemos de onde vieram.

Um projeto de dança, pode ser todo ele composto de momentos sucessivos de gesto? O palpite que se dá é de que isso é impossível. Sempre que falarmos em 
totalidade deveremos nos esquecer do gesto. Além de ser exaustivo para os participantes viver constantemente na vertigem do gesto, é preciso ter em mente que somos seres submetidos à força da gravidade. Não dá para passar muito tempo flutuando no ar, no salto que se dá entre uma "pedra" e outra. O engajamento dos participantes talvez se dirija sim à uma busca constante pelo gesto, uma busca infinita, entretanto, em alguns momentos é preciso saber pousar, repousar, se retirar. A potência da presença só se marca porque há ausência.

Didi-Hubermann fala de uma dança en réserves et en éclats ${ }^{40}$. (DIDIHUBERMANN, 2006, p. 18). Um dançarino, não deve se mostrar, deve aparecer. E para isso, precisa criar as condições espaço-temporais da sua ausência. Ele não mostra o que sabe fazer o tempo todo, mas faz surgir, em momentos imprevisíveis, explosões de uma energia física misteriosa. Na reserva de uma grande força, nos intervalos e nas suspensões, são criadas as condições para que se deem as explosões. O corpo guarda sua reserva até o ponto da explosão.

A Dramaturgia do Gesto é uma dramaturgia de passagens, que não se fecha nela mesma. Ela está sempre em recomposição, nunca se acomoda. "Passagem não é já passado; é em passagem" (ROCHA, 2012, p. 116). O evento performativo, apesar de ter uma duração, não pode ser dividido entre "apresentação do conflito, clímax, resolução", porque ele não é um conjunto de blocos temporais e de episódios correspondentes a um desenvolvimento cronológico linear em uma sucessão de causas e consequências. Os tempos se misturam, se antecipam, se atrasam, se repetem, se suspendem. Seus acontecimentos não se operam através de uma relação de causa e consequência, nem em uma relação de verticalidade (que pressupõe uma hierarquia: um objeto acima do outro, uma parte mais importante ou um performer "principal”). O que não está em evidência na cena é tão necessário quanto aquilo que se destaca. O que se coloca na penumbra tem a mesma relevância para esta dramaturgia que aquilo que é iluminado pelo refletor.

\footnotetext{
"Sob o arco da passagem, o corpo experiência o tempo das simultaneidades, contemporaneidade intrínseca ao gesto dançado - diferença discreta. Tempo feito de outra matéria, ou de sua própria, experienciado (ou vivenciado) sem a necessidade da conversão às coordenada espaciais para a sua visualização e consequente compreensão. Não mais um tempo de puro fluxo sempre a "frente" e sempre em ruptura em relação ao passado". (ROCHA, 2012, p.117)
}

\footnotetext{
40 Minha tradução: “em reservas e explosões”.
} 
O teatro burguês dramático tem a relação frontal como referência espacial estabelecida pelo "palco italiano". A função do olhar é centralizada, nesta perspectiva Ocidental, como herança do Renascimento. O público, de frente para o palco, assiste os atores dentro da caixa cênica, que por sua vez, protegidos por uma "quarta parede", apostam no eixo frontal do corpo virado para a plateia como referência de direção. As áreas chamadas "baixas" correspondem à frente do palco, as "altas" ao fundo . O que se coloca no centro nesse tipo de encenação é de maior valor. $\mathrm{O}$ centro do palco é um lugar hierarquicamente privilegiado para onde o olhar converge.

Em contraponto a isto, a dança e o teatro contemporâneos, devidamente alimentados pela quebra da "quarta parede", pelas performances que aspiram romper com um espaço diferenciado de "representação" e em diálogo com todo um sem fim de referências no campo das artes, sobretudo no cinema e nas Artes Visuais (sempre bom relembrar: o rompimento com a moldura do quadro, o abandono aos museus, a própria vida como obra), muda sua relação com o centro, mesmo que a realização de um espetáculo se dê sobre um palco italiano. A dança indaga: existe um centro do corpo? Onde ele fica? Por que definimos que a parte onde estão os olhos e os orgãos reprodutores é a frente e onde estão as costas e as nádegas, a parte de trás?

João Saldanha, na residência mencionada anteriormente, evoca a proposta da coreógrafa de dança moderna e contemporânea Martha Graham que, grosso modo, faz referência a um centro-motor energético no corpo do ator, ligado a respiração de onde toda a força se irradia o movimento. Esse centro pode ser ativado qualquer que seja a relação do corpo diante dos eixos espaciais e não compreende somente a proporção de um corpo em pé e frontal. João Saldanha, a partir de Graham anuncia: "O centro sou eu" e desafia os participantes da pesquisa a trabalharem sobre a imagem de um “corpo-árvore.” Onde é a frente da árvore? O corpo que dança desafia a direção de um corpo produtivo, que marcha sempre em frente. Como uma árvore, ele não possui frente, lado e costas. Da mesma forma, podemos pensar em relação ao que está em cima e ao que está embaixo. Neste outro tipo de orientação, o corpo dança por todos os eixos, por todos os vetores. E assim é possível expandir essa lógica, ao corpo no espaço. O corpo que se desloca como árvore é sempre centro em relação ao que está à sua volta. Ao mesmo tempo, este corpo está no entorno dos corpos que o rodeiam. Não há um centro único no espaço que possa ser mapeado no 
palco ou na sala, visto que a relação entre centro e entorno se dá através de uma interação entre referenciais.

Do mesmo modo, como já vem sendo visto na abordagem sobre o tempo, o depois não é "para frente" e o antes não é "para trás". A relação temporal também se relaciona com as demandas do seu entorno. A montagem de "A Sagração da Primavera", de Nijinsky, dialoga com determinados estímulos e pulsões que não são os mesmos da montagem de Pina Bausch. Aliás, as questões da montagem feitas por Pina na época da estreia não são as mesmas que as apresentadas hoje, após a sua morte. Ao contrário do que pode parecer, isso nos mostra que uma obra com gesto, não se fixa à sua época, mantendo-se a mesma ao logo dos tempos. Ela se reinventa a todo instante e o tempo ao qual ela responde é o tempo dos acontecimentos que a afetam.

Um trabalho com o gesto provavelmente flertará com a sensação de loucura e de estranhamento. Isso não quer dizer que sua proposta não seja embasada e que ela não lide com o real. Contudo, a impressão de estranheza e insanidade pode ser provocada pelo distanciamento de uma certa noção de coerência, que diz respeito a um padrão "ideal” de saúde física e psíquica. A sensação é de que alguma coisa está fora da ordem. E realmente está. Ainda assim é preciso estar engajado na coerência do desarranjo. Ser realmente desarranjado. A coerência que se busca é de uma outra ordem, sem paz, e tem a ver com uma coerência sobre o desejo.

Os operadores de gesto lembram um pouco os Bobos da Corte: homens, na maioria das vezes, com algum tipo de deficiência (anões ou corcundas, por exemplo), cujo ofício é entreter o rei ou a rainha, fezendo-nos rir. Declamam poesias, tocam instrumentos e são responsáveis por entreter as festas. Dizem de dentro do palácio aquilo que o povo gostaria de dizer ao rei e zombam da corte na própria corte. Com ironia, revelam as discordâncias mais íntimas e expões as ambições da monarquia. 


\section{5}

\section{(In)conclusão}

O gesto aspira uma reformulação constante da linguagem. Um outro modo de encarar o mundo e de responder a ele. Poderíamos dizer que o gesto está sempre em busca da novidade, mas não para ditar modas e tendências (por mais que sirva de influência para outros gestos). A novidade do gesto lida com uma turbulência. Pensamos, a princípio, que todos os artistas, críticos e espectadores, teriam o gesto como expectativa. Todavia, não é sempre que se aceita viver diferente. Tem quem goste de ver as mesmas coisas do mesmo jeito. Por outro lado, também não basta apenas querer "inventar" um estilo, uma escola, uma linguagem só para ser “diferente". Se o gesto tem como princípio não ser reconhecido em uma totalidade, não há como impôr uma mudança só pelo desejo de ser reconhecido pela autenticidade.

Em uma carta para Hélio Oiticica (CLARK 1998, p. 33-35), Lygia Clark conta suas experiências em visitas a galerias de arte e museus, em Paris. Nesta narrativa, ela identifica uma crise terrível na arte, dizendo: "você vê todos em busca de uma originalidade pela originalidade" (CLARK, 1998, p. 34). Para Lygia (e nós nos apropriamos), de nada adianta pensar apenas na forma, na figura ou na estrutura. Sem dúvida, tudo isso é fundamental para o trabalho artístico, mas é preciso que o homem corra atrás de uma nova expressão que se confronte com uma nova ética. Palavras de Lygia: "O que resta? Novas estruturas a descobrir. (...) Estruturas que correspondam absolutamente a novas necessidades de o artista se expressar. Arte agora é arte de culhões. Quem não os tiver está por fora" (CLARK, 1998, p. 34). A demanda do gesto é da ordem da necessidade. E é preciso de coragem para ir ao seu encontro, pois é certo que se enfrentará muita resistência.

Recentemente assisti na internet ao vídeo da releitura de "A morte do Cisne", realizada em 2011, pelo jovem bailarino goiano, até então desconhecido pela maioria, John Lennon da Silva. Candidato de um programa de auditório que dá destaque a novos talentos da dança, o rapaz do grupo de street dance "Amazing Break", foi orientado pelo coreógrafo Luis Ferron a desenvolver um solo, baseado no trecho $O$ Cisne, de O Carnaval dos Animais, escrito por Saint- Saëns e dançado pela russa Anna Pavlova. Independente de ter sido ou não uma cena forjada pela emissora, o 
fato é que segundos antes da sua apresentação John Lennon aparece sendo ridicularizado por uma das juradas, devido a sua roupa mais informal, de skatista, que segundo ela não era um figurino "adequado" à "importância" da obra à que fazia referência. Entretanto, logo em seguida, a impressionante apresentação de John Lennon, que mistura o balé clássico com a dança de rua, arranca aplausos e lágrimas dos jurados e milhares de acessos ao vídeo na internet. Uma cena melodramática, sim (afinal, ela se insere no contexto de uma empresa de televisão), mas certamente impactante. Qual terá sido o gesto de John Lennon? Onde estará o seu gesto? Na atitude tomada, de se inscrever em um programa de auditório e apesar do desencorajamento e de não ser reconhecido como bailarino "profissional", apresentar aquilo que é a sua dança? Nos movimentos ondulatórios de seus braços, que são como a água de um lago em dia de brisa; na torção da sua escápula com o braço erguido e o punho perpendicular, que remete indubitavelmente a um cisne (é e não $e ́$ um cisne)? No encontro entre a dança de rua (já reconhecida em alguns nichos, mas ainda à margem; uma modalidade nascida e crescida nas periferias) e a célebre peça clássica de Saint-Saëns, relida inúmeras vezes em todo o mundo, apresentada em grandes teatros frequentados pelas elites? Como narrar o lugar em que tanto o street dance, quanto o balé clássico, a partir da técnica, abdicam da técnica, dando a ver uma outra coisa? Eu poderia colocar outras questões a partir do trabalho de John Lennon da Silva, acerca de coisas que me tocaram. Mas ainda há questões que não consigo formular. Entre mim e John Lennon houve gesto, isso eu acho que posso dizer. Se levarmos em consideração as lágrimas dos jurados, até então incrédulos, que acabam por se contradizer no próprio programa de televisão que os contratou; também é possível falar sob essa perspectiva. Como instância de poder soberana, que atribui valor a um trabalho artístico, os jurados se mostram fragilmente desarticulados. Isso sem contar a quantidade de acessos que o vídeo vêm conquistando na internet.

"A morte do cisne", na versão de Ana Pavlova (e acreditamos que isto esteja absolutamente inscrito na dramaturgia de Lennon da Silva), apresenta a morte de um cisne ferido. Há uma antiga crença que afirma que os cisnes passam a vida inteira mudos e antes da morte cantam uma triste canção. Assim, podemos pensar que o gesto na dramaturgia faz com que nos aproximemos dos corpos despedaçados, feridos, que dão seu último grito, anunciando a efêmera e constante passagem entre vida e morte. 
"O poema nos permite tocar a força da crueldade na falência do projeto humano da sociedade. Ele se inclina para o minúsculo, fazendo com que nos aproximemos desses corpos despedaçados que Artaud vai construir. Ele traz para o seio do homem a possibilidade de transformação, tocando assim a revolução tal qual Artaud entendia: uma revolução dos corpos minuscularizados que é física, fisiológica, anatômica, funcional, circulatória, respiratória, dinâmica, atômica e elétrica ${ }^{41}$ ". (KIFFER, 2003, p. 157)

Uma dramaturgia do gestos, lida (aqui dizemos com influência de Artaud) com a "crueldade" de um corpo que não se completa, que se constrói pelo seu despedaçamento. Ao contrário de uma dramaturgia psicológica, seu corpo não se articula em função dos encaixes, da lógica ou de uma racionalidade ligada a causas e consequências.

Desta forma, o gesto na dramaturgia nunca poderá se transformar em técnica, em escola, em regra ou finalidade. Escrever e ler sob a perspectiva do gesto se faz a partir do desejo por um corpo para além das definições, das catalogações e dos nomes. Não há nenhum método que garanta a "aprendizagem" do gesto, assim como não há um procedimento que ensine alguém a "tornar-se" artista ou "leitor de arte". O máximo que se pode fazer é despertar sensibilidades, apresentar estímulos sensíveis, afetivos, poéticos e teóricos. Não há um modo mais adequado de "produção" ou de "recepção" do gesto. Tentarão dizer o que é o gesto em determinado trabalho artístico, em determinada ação política, em determinado modo de existência, e muitas vezes até parecerão convincentes. Muitos ficarão aliviados com a ilusão de que um gesto se adequa à linguagem comum e à interpretação (“Ah! Finalmente entendemos! Finalmente apreendemos!"). Todavia, a marca que o gesto deixa não tem segurança, nem paz.

A dramaturgia lida com o efêmero encontro entre corpos. E o que interessa à esta abordagem é a maneira como a presença se manifesta para além de um “presente” localizável em uma linha cronológica. A presença do gesto investe em outras "presenças" anteriores à ela própria e sobrevive mesmo depois da experiência, indicando uma noção de "vida" que não se restringe à atividade dos organismos. O corpo do gesto, em seu incessante movimento de desfazimento e refazimento ${ }^{42}$,

\footnotetext{
41 Trecho em itálico é uma citação de uma carta de Artaud à Breton, escrita em 1947.

${ }^{42}$ Noção de refazimento e desfazimento em referência ao capítulo "O endereçar: precisão, presença e crueldade" (KIFFER, 2003: 157-170).
} 
ultrapassa suas funções orgânicas. Vida e morte não são categorias antagônicas. É possível "morrer" em cena e sobreviver centenas de anos depois.

O corpo não se restringe à fisicalidade. Pensar (com) o corpo não é só pensar a matéria e o movimento. "Pina Bausch disse uma vez, inquirida a respeito de tão pouca dança em seus espetáculos, qualquer coisa como: é preciso fazer ainda outras coisas para depois voltar a dançar” ( ROCHA; TIBURI, 2012, p. 87). O gesto na dança busca uma aproximação máxima dessas "outras coisas": forças outras, que podem ou não estar nos movimentos. O gesto procura encontrar-se com "isso" que não tem um só nome, reconhecendo a própria falência e incapacidade de se chegar a um destino final. Ao mesmo tempo em que o gesto precisa de corpos para se manifestar, ele indica uma percepção do corpo para além do que é físico ou pelo menos do que se atribui como elementos de fisicalidade; como por exemplo, a forma, o visível e o tangível. É claro que o olhar sobre o corpo implica em um aspiração ao tato: "a noção de gesto se abre, permitindo pensá-la sob a égide do contato e do toque" (KIFFER, 2013) ${ }^{43}$, mas o próprio toque pode se fazer para além da fricção direta entre peles de um corpo humano perecível ou entre superfícies de outros corpos. Se por um lado a escrita cênica no teatro ou na dança se faz na própria carne dos participantes ( ela se escreve ao mesmo tempo em que se inscreve nos corpos), por outro, há no apelo ao gesto, um toque e um contato de uma outra natureza.

A "cena" não é uma reflexão apartada da "vida". Arte e vida estão inteiramente contaminadas, desafiando os seus próprios limites, diluindo fronteiras daquilo que se compreende como "artista", "espectador" e "cidadão". A escrita dramatúrgica, sob a lente do gesto, convida o espectador a tocar a cena com o olhar, com a respiração, com os afetos, com a presença. Um projeto artístico cuja escrita toca a sua própria leitura crítica; toca o espectador e é por ele tocado; toca o mundo em que se constrói.

Qualquer escrita observada pela perspectiva do gesto deveria atravessar os dias e os minutos se apagando, se reescrevendo, acrescentando novas passagens, se contradizendo, não se entendendo. A dramaturgia, ao lidar com o "agora" do encontro, talvez tenha uma chance ainda maior de colocar na prática esse movimento.

\footnotetext{
${ }^{43}$ Texto apresentado no Seminário Teatralidades na literatura e na arte contemporânea, organizado por Ângela Dias e Paula Glenadel.
} 
Nunca um texto final. Uma escrita sem conclusões, um teoria ou um conceito sem verdades absolutas, uma cena sem respostas, um corpo que só se compõe pela sua própria decomposição. Este é o desejo. No caso, participar de uma experiência cênica ou de qualquer experiência em arte, ciente de que no fundo tudo o que aquela experiência é capaz de proporcionar é a própria experiência.

"Para que fui solicitado? Porque me irritei? Porque é que o meu coração estava a bater tão depressa? Porque me arrepiei? Que havia no espetáculo que não me deixou igual? Isto tem uma dimensão política que começa com o acto de percepção. Ou seja, não permitir que o espectador sinta apenas aquilo a que já está habituado a sentir, seja pela realidade ou qualquer convenção teatral. E é isso que eu chamo de ritual performático". (COSTA, 2006)

O que se deseja pela via do gesto é uma mudança radical de mundo e não uma interpretação de mundo ${ }^{44}$. Espectador, artistas e teóricos são corresponsáveis por fazer alguma coisa com aquilo que lhes é dado na cena-vida, tanto em uma esfera mais pessoal, quanto em uma esfera de maior abrangência e de maior atuação política.

É preciso procurar novas formas de existência sobre esse palco-mundo, formas que nunca foram encontradas, formas nunca antes experimentadas. A vertigem de dançar quantos desenhos forem possíveis, tentar voar, virar um animal, um touro ou uma lesma. Encaixar, penetrar, sustentar outros corpos, meus corpos, extra-corpos, nossos corpos, corpos de ninguém. Experimentar outros ritmos, cadências, volumes, pulsações. Outros eixos: ver as coisas de cabeça para baixo. Perder uma perna, perder a cabeça, ser um gigante e ser um anão. Não fazer nada. Permanecer. Assistir não com os olhos, mas com o tato. Esfregar-se nas coisas. Tocar não apenas pelo tato, mas pela escuta, pelo cheiro, pela imagem, pelo medo, pelo desejo de atravessar uma experiência coletiva. Deixar-se tocar por aquilo que não se sabe dizer, tentar dizer assim mesmo, gaguejar e conformar-se em não conseguir dizer precisamente. Não conformar-se e recomeçar. Passar pela agonia e pelo prazer do informe. Surpreender-se com o óbvio, ver diferente o que se vê todo o dia. Quando sentir-se sozinho, dançar com essa solidão ${ }^{45}$. Sentir que essa solidão é sua, tão sua,

\footnotetext{
${ }^{44}$ Frase inspirada na performance "Cosmocartas", com direção de Renato Linhares e atuação de Álamo Facó e Cristina Flores, com temporada entre dezembro de 2013 e fevereiro de 2014, no Centro Cultura Hélio Oiticica (RJ).

45 Inspirado no texto "Le Danseur des Solitudes" (DIDI-HUBERMANN, 2006).
} 
mas saber também que a solidão é sentimento comum e partilhado e que é através dela que muitas vezes se encontra companhia. 
6

\section{Referências Bibliográficas}

AGAMBEN, Giorgio. Profanações. Tradução: Silvino José Assmann. São Paulo: Boitempo, 2007

Means without end: notes on politics. Trad. Vicenzzo Binetti e

Cezari Casarino. Estados Unidos: University of Minnesota, 2000

Notas sobre o gesto. In: Revista Artefilosofia. n.4. p.09-14. Ouro Preto: IFAC, 2008

Desnudez. Trad. Mercedes Ruvituso y María Teresa D’Meza. Buenos Aires: Adriana Hidalgo Editora, 2011

AMORIM, Claudia, Org; GREINER, Christine, Org. Leituras do Corpo . $2^{\mathrm{a}}$ ed. Organização de Christine Greiner e Claudia Amorim. São Paulo: Annablume, 2010. (Coleção Leituras do Corpo).

ANDRADE, Mário. Danças dramáticas do Brasil. $3^{\mathrm{a}}$ ed. Organização Oneyda Alvarenga. Belo Horizonte, Brasília: Itatiaia/Instituto Nacional do Livro/Fundação Nacional Pró-Memória, 1982 (3 tomos)

ANTENORE, Antônio. Nossa aposta: John Lennon da Silva. In: Revista Bravo! Caderno de Teatro e Dança, ed. 164, abril 2011. Arquivo em formato digital. Disponível em: http://bravonline.abril.com.br/materia/nossa-apostajohn-lennon-silva 
ARAÚJO, Antônio. O Processo Colaborativo no Teatro da Vertigem. In: Revista Sala Preta- Revista do Programa de Pós-Graduação em Artes Cênicas, vol 6, n. 1, 2006, pp.155-164. Arquivo em formato digital. Disponível em:

http://www.revistasalapreta.com.br/index.php/salapreta/article/view/174/172

ARTAUD, Antonin. O Teatro e seu Duplo. Trad. Teixeira Coelho. $1^{\text {a }}$ ed. São Paulo: Martins Fontes, 1999

Van Gogh: O Suicida da Sociedade. Trad. José Olympio. Rio de Janeiro: José Olympio, 2003

BAULIEU, Alain. Cuerpo y acontecimento: la estética de Gilles Deleuze. Trad. Augustin Kripper e Luciano Luterau. Buenos Aires: Letra Viva, 2012

BARTHES, Roland. Escritos sobre teatro. Trad. Mário Laranjeira. $1^{1 \mathrm{a}}$ ed . São Paulo: Martins Fontes, 2007

Inéditos e Dispersos. Trad. Ivone Castilho Bernedetti. $1^{\text {a }}$ ed. São Paulo: Martins Fontes, 2005

O Neutro. Trad. Ivone Castilho Bernedetti. $1^{\underline{a}}$ ed. São Paulo: Martins Fontes, 2003

O Óbvio e o Obtuso. Trad. Léa Novace. Rio de Janeiro: Nova Frontera, 1980

BECKETT, Samuel. O Inominável. Trad. Ana Helena Souza. São Paulo: Globo, 2009 
BENJAMIN, Walter. Que é Teatro Épico? Um Estudo Sobre Brecht. In: Magia e Técnica, Arte e Política: ensaios sobre literatura história da cultura. Trad. Sergio Paulo Rouanet. 14 ed. São Paulo: Brasiliense, 1994 (Obras Escolhidas, vol1).pp 78-90.

BLANCHOT, Maurice. A Conversa Infinita 3: A ausência de livro, o neutro o fragmentário. Trad. João Moura Jr. São Paulo: Escuta, 2010

BOGART, Anne. A preparação do diretor: sete ensaios sobre arte e teatro. Trad. Anna Vianna. São Paulo: Martins Fontes, 2011

BOGART. Anne e LANDAU, Tina. The Viewpoints Book: A pratical guide to viewpoints and composition. New York: Theatre Communications Group, 2005.

BONFITTO, Matteo. O Ator Compositor. São Paulo: Perspectiva, 2011

O Ator Pós-Dramático: Um Catalisador de Aporias? In: Guinsburg, J. e Fernandes, Silvia (orgs.). O Pós-Dramático. São Paulo: Perspectiva, 2010

BROOK, Peter. A porta aberta: reflexões sobre a intrepretação e o teatro. Rio de Janeiro: Civilização Brasileira, 2011.

CLARK, Lygia; OITICICA, Hélio. Cartas,1964-74. Organizado por Luciano Figueiredo. Rio de Janeiro: Editora UFRJ, 1998.

COHEN, Renato.Performance como Linguagem. São Paulo, Perpectiva, 2009.

COSTA, Tiago Bartolomeu. O olhar crítico: Erika Fischer-Lichte. Arquivo em formato digital. Disponível em: http://omelhoranjo.blogspot.com.br/2006/11/oolhar-crtico-erika-fisher-lichte.html.

CÉSAR, Ana Cristina. Poética. São Paulo: Companhia das Letras, 2013 
CYPRIANO, Fabio. Pina Bausch. São Paulo, Cosac Naify: 2005.

DANTO, Arthur C. A Transfiguração do Lugar-Comum: uma filosofia da arte. Trad. Vera Pereira. São Paulo: Cosac Naify, 2009

DELEUZE, Gilles. O que é um dispositivo? Arquivo em formato digital, s/d. Disponível em http://michel-foucault.weebly.com/textos.html. Tradução de Wanderson Flor do Nascimento de "Que és un dispositivo?" In: Michel Foucault, filósofo. Barcelona: Gedisa, 1990

Francis Bacon: lógica da sensação. Equipe de tradução Roberto Machado (coordenação). Rio de Janeiro: Jorge Zahar Ed., 2007 a.

DELEUZE, Gilles. Lógica do Sentido. Trad. Luiz Roberto Salinas Fortes. São Paulo: Perspectiva, 2011

Sobre o Teatro: Um manifesto de Menos; O esgotado. Trad. Fátima Saadi, Ovídio Abreu e Roberto Machado. Rio de Janeiro: Jorge Zahar, 2010

Pintura: el concepto de diagrama. Trad. Esquipo editorial Cactus. Buenos Aires: Cactus, 2007b

DELEUZE, Gilles e GUATTARRI, Félix. Mil Platôs: capitalismo e esquizofrenia, vol 2. Trad. Ana Lúcia de Oliveira e Lucia Cláudia Leão. São Paulo: Ed. 34, 2011

Mil Platôs: capitalismo e esquizofrenia, vol. 3. Trad. Aurélio Guerra Neto, Ana Lúcia de Oliveira, Lúcia Cláudia Leão e Suely Rolnik. São Paulo: Ed. 34, 1996 
Mil Platôs: capitalismo e esquizofrenia, vol. 4. Trad. Suely Rolnik. São Paulo: Ed. 34, 1997.

DIDI-HUBERMANN, Georges. Arenas: ou les solitudes spatiales. In: Le Danseur des Solitudes. Paris: Les Éditions de Minuit, 2006

A Dialética do Virtual ou o Jogo do Esvaziamento. In: 0 que vemos, o que nos olha. São Paulo: Ed. 34, 1998

EUGÊNIO, Fernanda e FIADEIRO, João. O Jogo das Perguntas. Lisboa: Editora Ghost, 2013

FABIÃO, Eleonora. "Corpo Cênico, Estado Cênico". In: Revista Contraponto, vol. 10, n.3, s/d. Arquivo em formato digital. Disponível em: http://www6.univali.br/seer/index.php/rc/article/view/2256.

FÉRAL, Josette. Por uma poética da performatividade: o teatro performativo. In: Revista Sala Preta, Revista do Programa de Pós-Graduação em Artes Cênicas, Eca/USP, São Paulo, n. 08, 2008, p.197-210

FERANDES, Ciane. Pina Bausch o Wuppertal Dança-Teatro: Repetição e Transformação. $2^{a}$ ed. São Paulo: Annablume, 2007

FERNANDES, Silvia. Teatralidades Contemporâneas. São Paulo: Perspectiva: Fapesp, 2010.

Teatralidade e Performatividade na Cena Contemporânea. In: Revista Repertório: Teatro e Dança. Salvador, n. 16, p. 11-23, 2011. Arquivo em formato digital, disponível em: http://www.portalseer.ufba.br/index.php/revteatro/article/viewFile/5391/3860. 
FIADEIRO, João. "Composição em Tempo Real". In: La Porta. Arquivo em formato digital. Disponível em: http://laportabcn.com

FOUCAULT, Michel. Dos Espaços Outro. In: O Espaço na Vida Social. Instituto de Estudos Avançados da Universidade de São Paulo. Vol. 27, n. 79. Arquivo em formato digital. Disponiível em: http://www.scielo.br/scielo.php?pid=S0103$\underline{40142013000300008 \& \text { script=sci arttext }}$

Microfísica do Poder. Org. e trad. Roberto Machado. Rio de Janeiro: Edições Graal, 1979

A ordem do discurso. Aula inaugural no Collège de France, pronuncaida em 2 de dezembro de 1970. Trad. Laura Fraga de Almeida Sampaio. $20^{a}$ ed. São Paulo: Edições Loyola, 2010b

FISCHER-LICHTE, Erika. Estética de lo performativo. Madrid: Abada, 2011.

A cultura como performance: desenvolver um conceito. In: Sinais de Cena - APCT. Lisboa, N. 4, p. 73-81, dezembro de 2005.

GIL, José. Metamorfoses do Corpo. Lisboa: Relógio D’água, 1997.

Monstros. Lisboa: Relógio D’Água, 2006.

GONÇALO, Pablo. Dramatúrgia da Dúvida- um tríptico binário e não linear. In:

Revista Cinética- Cinema e Crítica. Arquivo em formato digital, 2013. Disponível em: http://revistacinetica.com.br/

GOLDBERG, Rosalee. A Arte da Performance. São Paulo, Martins Fontes, 2006. 
GUMBRECHT, Hans Ulrich. Produção de presença perpassada de ausência. Sobre música, libreto e encenação. In: Revista PaLavra (Departamento de Letras Puc-Rio).

Produção de Presença: o que o sentido não consegue transmitir. Rio de Janeiro: Contraponto: Ed. PUC-Rio, 2010.

KIFFER, Ana. Antonin Artaud: uma poética do pensamento. Coruña: Biblioteca- Arquivo Teatral <<Francisco Pillado Mayor>>, 2003.

Teatro e Vida: dobras, passagens, limites e saídas. In: Teatralidades. Org. DIAS; A. GLENADEL, P., Instituto de Letras. Rio de Janeiro: Universidade Federal Fluminense, 2013.

O traço plástico-poético em Antonin Artaud. In: SCHØLLHAMMER, Karl Erik; OLINTO, Heindrun Krieger (Orgs.). Literatura e Imagem. Rio de Janeiro: Edições Galo Branco, 2005

Sobre limites e corpos extremos. In: SCHØLLHAMMER, Karl Erik; OLINTO, Heindrun Krieger (Orgs.). Literatura e Criatividade. Rio de Janeiro: 7Letras, 2012

KATZ, Helena. O Corpo como Mídia do seu Tempo: a pergunta que o corpo faz.CD-Rom Rumos Itaú Cultural Dança. Itaú Cultural São Paulo, 2004. Disponível em: http://www.scribd.com/doc/84831526/O-corpo-como-midia-deseu-tempo.

KLAUSS, Vianna. A Dança. São Paulo: Summus, 2008

LAPOUJADE, David. O Corpo que Não Aguenta Mais. In: Nietzche e Deleuze, Que pode o corpo. Org. D. Lins. Rio de Janeiro: Relume Dumará, 2002 
LEHMANN, Hans-Thies. O Teatro Pós- Dramático. Tradução de Pedro Süssekind. São Paulo: Cosac Naify, 2007 Teatro Pós-dramático, doze anos depois. In: Revista brasileira de estudos de presença - UFRGS. V. 3, n. 3, 2013. Arquivo em formato digital. Disponível em: http://seer.ufrgs.br/presenca/article/view/39703

LIMA, Daniella. Gestos- práticas e discursos. Org: Daniella Lima, Mariana Aurélio, Silivia Soter. Coordenação: Adriana Maciel. Rio de Janeiro: Cobogó, 2013.

MACHADO, Roberto. Deleuze e a Literatura. In: Deleuze, a arte e a filosofia.

Rio de Janeiro: Jorge Zahar, 2010.

LOUPPE, Laurence. Poética da Dança Contemporânea. Trad. Rute Costa. Lisboa: Orfeu Negro, 2012

NANCY, Jean-Luc. Corpus. Paris: Éditions Métailié, 2000 La Possibilité d'un Monde: Dialogue avec Pierre-Philippe Jandin. Paris: Les Petits Platons (Les dialogues des Petits Platon), 2013. L'Intrus. Paris: Galilée, 2010

NIETZCHE, Friederich. O Nascimento da Tragédia ou Helenismo e Pessimismo. Trad. J. Guinsburg. São Paulo: Companhia das Letras, 2007.

NOVARINA, Valère. Diante da Palavra e Debate com o Espaço. In: Diante da Palavra. Tradução de Ângela Leite Lopes. $2^{\underline{a}}$ ed. Rio de Janeiro: 7 letras, 2009, pp 11-24 e 31-48. 
PAIS, Ana. O Crime Compensa ou o Poder da Dramaturgia. In: Temas para a Dança Brasileira. Organização de Sigrid Nora. São Paulo: Edições SESC SP, 2010.

PARR, Adrian. The Deleuze Dictionary Revised Edition. Endinburgh: Endinburgh University Press, 2010.

PELBART, Peter Pal. Da clausura do fora ao fora da clausura: loucura e desrazão. São Paulo: lluminuras, 2009.

Vida capital: ensaios de biopolítica. São Paulo: ed. lluminuras, 2003

Encontros Provocativos 7/9- Bienal SESC de dança. Conversatório/Convivência - SESC Santos. Arquivo em formato digital disponíbel em: http://revistapolichinelo.com.br

RAMOS, Nuno. O Mau Vidraceiro. São Paulo: Globo, 2010.

RANCIÈRE, Jacques.O Espectador Emancipado. In: Revista ArtForum. Trad: Danielle Ávila. Arquivo disponível em formato digital, 2007. Disponível em: http://www.questaodecritica.com.br/2008/05/o-espectador-emancipado/

REZENDE, Renato; SANTOS, Roberto Corrêa. No contemporâneo: arte e escritura expandidas. Rio de Janeiro: Editora Circuito/ FAPERJ, 2011

RINALDI, Miriam. O Ator no Processo Coaborativo no Teatro da Vertigem. In: Revista Sala Preta - PPGAC. Vol 6, n. 1, 2006, pp.155-164. Disponível em: http://www.revistasalapreta.com.br/index.php/salapreta/article/view/174/172. Último acesso em: 1/10/2013

RISCADO, Caio. Dramaturgia Compartilhada. 2013, 127 f. Dissertação (Mestrado em Artes Cênicas. Programa de Pós-graduação em Artes Cênicas da UNIRIO. Rio de Janeiro, 2013. 
ROCHA, Thereza; TIBURI, Marcia. Diálogo/Dança. São Paulo: editora Senac São Paulo, 2012

ROLNIK, Suely. Cartografia Sentimental, Transformações

Contemporâneas do Desejo. São Paulo: Editora Estação Liberdade, 1989

SANTOS, Pedro Fraga dos. Dispositivos e Diagramas na filosofia de Michel Foucault. 2007. 220 f. Tese (Doutorado em Filosofia)- Instituto de Filosofia, Universidades Estadual do Rio de Janeiro, Rio de Janeiro, 2007

SARRAZAC, Jean-Pierre. Léxico do Drama Moderno e Contemporâneo. São Paulo: Cosac Naify, 2012.

TROTTA, Rosyane. "Autoralidade, Grupo e encenação". In: Revista Sala Preta - PPGAC. Vol 6, n. 1, 2006, pp.155-164. Disponível em: http://www.revistasalapreta.com.br/index.php/salapreta/article/view/177.

UNO, Kuniichi. A Gênese de um Corpo Desconhecido. Trad. Christine Greiner. São Paulo: n-1 Edições, 2012.

VARELLA, Flávia Florentino. Verdade, Sentido e Presença: História e Historiografia em Heidegger e Gimbrecht. In: Revista Opsis. Departamento de História e Ciências Sociais. V. 7. N.9. Goiás: UFG, jul-dez de 2007.

ZUMTHOR, Paul. A letra e a voz. São Paulo: Companhia das Letras, 1993, p.15-54. 
Referências Filmográficas:

Valse Wals Film. Direção: Mark de Cloe. Produção de Orkater e AVRO tv. Holanda: 2005. 62 min.

The Cost of Living. Lloyd Newson. Produção de DV8 films LTDA e Chanel 4 Television, baseado na produção para o palco The Cost of Living, produzida e dirigida por Lloyd Newson. Reino Unido: 2005. $35 \mathrm{~min}$.

Blush. Win Vanderkeybus. Bélgica e França. Produção de CCP, Sciapode e Companhia Última Vez. Bélgica e França: 2005. 53 $\min$. 